JINNAH

BUSINESS

REVIEW
Volume 2 Number 2 July 2014

Online ISSN 2307-7921

Print ISSN 2070-0296
The Combined Effect of Psychological Capital and Psychological Contract Breach on Employees' Outcome

Effect of Emotional Intelligence and Financial Literacy on Investment Decision Making with a Mediating Role of Risk Perception

Factors Affecting Consumers' Attitude Towards Mobile Marketing in Pakistan

Impact of Personality on Absenteeism: Moderating Role of Ethical Orientation
Procedural Justice, Envy and Organizational Citizenship Behavior: A Study of Health Professionals in Pakistan

The Impact of Locus of Control on Training Transfer with Mediating Role of Job Satisfaction and Achievement Motivation

Learning Through Training and its Impact on Employee Performance: Moderating Role of Job Satisfaction Among Banking Sector Employees of Pakistan 


\section{EDITORIAL BOARD}

Patron-in-Chief

Editor-in-Chief

\section{Editorial Board}

Dr. Charles Martin

Dr. Bori Popesko

Dr. Jose M. Merigo

Dr. Osman Khan

Dr. Raihan H. Khan

Dr. Muhammad Zafar Iqbal Jadoon

Dr. Arshad Hassan

Dr. Zafar Moeen Nasir

Dr. Qaiser Abbas

Prof. Safdar Ali Butt

Dr. Kamran Naqi

Dr. Kashif-ur-Rehman

Dr. S. M. Raza Naqvi

Dr. Zulfiqar Shah

Dr. Rauf-i-Azam

Dr. Hamayun Naeem

Dr. Zulfiqar Ali Shah

Dr. Shazia Akhtar

Dr. Ishfaq Ahmad

Dr. Attiya Y. Javed

Dr. Syed Amir Shah

Dr. Zohra Jabeen

Dr. Zaheer Abbas

Dr. Khurrum Shahzad
Mian Amer Mahmood, Patron (M.A.J.U.)

Professor Dr. Sajid Bashir
(Wichita State University Wichita, United State of America)

(Tomas Bata University in Zlin Mostni, Czech Republic)

(University of Barcelona, Spain)

(University of East London, United Kingdom)

(University of New York Oswego, United State of America)

(University of Central Punjab Lahore, Pakistan)

(Mohammad Ali Jinnah University Islamabad, Pakistan)

(American University, United Arab Emirate)

(COMSATS Institute of Information Technology Islamabad, Pakistan)

(Mohammad Ali Jinnah University Islamabad, Pakistan)

(Hamdard University Islamabad, Pakistan)

(Iqra University Islamabad Campus, Pakistan)

(Mohammad Ali Jinnah University Islamabad, Pakistan)

(COMSATS Institute of Information Technology Islamabad, Pakistan)

(PMAS-Arid Agriculture University Rawalpindi, Pakistan)

(Foundation University Rawalpindi, Pakistan)

(Islamic International University Islamabad, Pakistan)

(Mohammad Ali Jinnah University Islamabad, Pakistan)

(University of Engineering and Technology Lahore, Pakistan)

(Pakistan Institute of Development Economics, Pakistan)

(Allama Iqbal Open University Islamabad, Pakistan)

(Institute of Management Sciences Peshawar, Pakistan)

(Islamic International University Islamabad, Pakistan)

(Riphah International University Rawalpindi, Pakistan)

\section{Editorial Team}

Mr. Amir Khan Khattak

Ms. Maria Mashkoor

Mr. Muhammad Bilal Saeed

Ms. Rumesa Pervez Khan 


\section{EDITOR'S NOTE}

Welcome to the Volume 2(2) of Jinnah Business Review. I am particularly thankful to my colleagues from different universities who appreciated quality of earlier volumes through emails, calls and official letters. It is undoubtedly a big encouragement for us.

The research methodology of any manuscript holds premier importance. As per customary trends in Pakistan, we prefer studies involving one paradigm of research, more often quantitative and rarely qualitative. However, contemporary trends in Management research also talks about a third paradigm which is the Mixed Method Research. Schwandt (2000, p.210) expansively portrays the need for having mixed method research:

"All research is interpretive, and we face a multiplicity of methods that are suitable for different kinds of understandings. So the traditional means of coming to grips with one's identity as a researcher by aligning oneself with a particular set of methods (or being defined in one's department as a student of "qualitative" or "quantitative" methods) is no longer very useful. If we are to go forward, we need to get rid of that distinction".

Mixed Methods Research appears to be a new starting point for business research as it takes benefit from the wisdom of both methods i.e. qualitative and quantitative. It provides practicable solution to resolve many research problems. I would request research scholars to explore this avenue for conducting useful and meaningful research in Pakistan.

Publication of a research journal involves efforts of many people. I am really lucky that since the launch of this journal, I have received unprecedented support and guidance of Dr. Muhammad Mansoor Ahmed, Executive Vice President and Dr. Arshad Hassan, Dean, Management Sciences, Mohammad Ali Jinnah University, Islamabad. Progress of this journal is a regular agenda item in Executive Committee meeting at Mohammad Ali Jinnah University, Islamabad, which shows involvement of Management for successful publication of the journal.

I also have support of four dedicated people in publication of Jinnah Business Review. Mr. Muhammad Bilal Saeed, Mr. Amir Khan Khattak, Ms. Maria Mashkoor and Ms. Rumesa Pervez Khan, who work indefatigably for timely publication of the journal. We all are making efforts to make Jinnah Business Review a quality journal, comparable to any international journal in coming years.

Prof. Dr. Sajid Bashir

Editor in Chief

Jinnah Business Review 


\section{TABLE OF CONTENTS}

1. The Combined Effect of Psychological Capital and Psychological Contract Breach on Employees' Outcome

2. Effect of Emotional Intelligence and Financial Literacy on Investment Decision Making with a Mediating Role of Risk Perception

3. Factors Affecting Consumers' Attitude Towards Mobile Marketing in Pakistan

4. Impact of Personality on Absenteeism: Moderating Role of Ethical Orientation

5. Procedural Justice, Envy and Organizational Citizenship Behavior: A Study of Health Professionals in Pakistan

6. The Impact of Locus of Control on Training Transfer with Mediating Role of Job Satisfaction and Achievement Motivation

7. Learning Through Training and its Impact on Employee Performance: Moderating Role of Job Satisfaction Among Banking Sector Employees of Pakistan 


\title{
THE COMBINED EFFECT OF PSYCHOLOGICAL CAPITAL AND PSYCHOLOGICAL CONTRACT BREACH ON EMPLOYEES' OUTCOME
}

\author{
ZIA UL ISLAM \\ Riphah International University, Islamabad, Pakistan
}

\begin{abstract}
The study is designed to investigate the impact of psychological contract breach on different employee's outcome, namely, organizational citizenship behavior, effective commitment and Job Satisfaction with the moderation effect of Psychological Capital. Out of 190 self-administered questionnaires distributed among the faculty members of private sector universities located in the Khyber Pakhtunkhwa province of Pakistan, 128 questionnaires were considered for analysis. The results show that there is a negative relationship between Psychological Contract Breach and all employees' outcomes under study. Psychological Capital is positively related to all employees' outcome. Psychological Capital moderates only the relationship between psychological contract breach (PCB) and organizational citizenship behavior, and doesn't moderate the relationship between PCB-Affective Commitment and PCB- Job Satisfaction.
\end{abstract}

\section{INTRODUCTION}

In today's organizations, Psychological Contract Breach (PCB) has emerged as a big problem, as it makes employees feel that organization is non-supportive to them. (Zagenczyk, Gibney, Kiewitzn \& Restubog, 2009). Psychological Contract is, "individual beliefs shaped by the organization regarding terms of an exchange agreement between individuals and their organizations" (Rousseau, 1995, p.9).Breach of contract occurs, when one side has the capability to obey the contract, but doesn't (Rousseau, 1995). Morrison and Robinson (1997) defined psychological contract breach as the employee's belief of the organizational failure to fulfill its obligations (Lange, Bal, Heijden, Jong, \& Schaufeli, 2011). When psychological contract is implemented, it leads towards improved performance and Organizational Commitment (Zhao, Wayne, Glibkowski \& Bravo, 2007), because psychological contract creates emotions and attitudes that shapes and controls behavior (Wangithi \& Muceke, 2012). On the contrary, PCB has anrgative impact on the employee's attitude and behavioral outcomes, including OCB (Restubog, Bordia \& Tang, 2007;Bal, Chiaburu \& Jansen, 2010) and correlates with deviant work place behaviors (Kickul, 2001).

This study is based on Affective Event Theory (AET) (Weiss \& Cropanzano, 1996) as a guideline for understanding PCB. According to AET, organizational events stimulate affective responses in individuals working in organizations that accounts for different workplace attitudes and behaviors. PCB is also a significant workplace event that triggers affective reactions of employees as proposed by (Zhao et al., 2007). Parzefall and Coyle-Shapiro (2010) are of the view that a single event may not be sufficient; rather, the accumulation of frequent small events may develop the perceptions of breach among employees. Bal, Chiaburu and Diaz (2011) linked AET with social exchange theory (Blau, 1964) by pleading that employees and organizations have mutual obligations to each other, and when the employees perceive that their organization has not rewarded their contribution, they will react emotionally. Social exchange between employee and employer may influence the perception of contract breach and its impact on employee's behaviors (Bal et al., 2010). When employees perceive that the social exchange relation is interrupted, they will exhibit unwanted behaviors (Chao, Cheung \& Wu, 2011).

There is a plethora of research on the concept of psychological contract fulfillment or breach (Brown \& Roloff, 2011). For example, Chambel and Alcover (2011) identified relationship of PC with satisfaction and civic virtue behaviors. Jamil and Raja (2013) found a positive link between PCB's perception and burnout. Bashir and Nasir (2013) studied the relationship between PCB and union commitments among the employees of the hospitality sector of Pakistan. Raja, Johns and Ntalianis (2004) related different personality characteristics with the relational and transactional perception of PC with psychological breach. Gerber, Grote, Geiser, and Raeder (2012) tested the moderating roleof the career type on the relationship between PCB and work attitude. Bal, 
Lange, Zacher and Heijden (2013) conducted a study to show the life-span perspective of PC and related it with continuous and normative commitment. Psychological Contract Violation was found negatively linked with affective Organizational Commitment by Bao, Olson, Parayitam and Zhao (2011). They also found this relationship moderated by the job and person related variables such as job involvement, Job Satisfaction, hope, job demand and locus of control. Bal et.al (2010) tested social exchange as a moderator of PCB outcomes relationships. Chao et al. (2011)tested attribution style and power distance moderating the relationship between PCB and Counterproductive workplace behaviors (CWB).

An exhaustive list of publications on this particular concept of PCB and its correlates is available along with multiple intervening and interacting variables. Some of it has being discussed above. This study is a unique attempt to introduce Psychological Capital as a moderator between PCB and positive employee's outcomes, thus adding to the available body of knowledge on this particular topic.

Teaching in the Private sector universities of Pakistan has become a lucrative profession since the last decade. One of the reasons for this sector's attractiveness is that HEC has announced very attractive packages to university teachers (Shahzad, Bashir \&Ramay, 2008). But a growing number of private sector universities put them in a stiff competition and under constant pressure to deliver maximum in terms of education and research publications. Moreover, in the quest for competent faculty, private sector universities mostly rely on visiting faculty, thus, leaving little room for full time faculty members. The faculty often experiences broken promises by the universities because of the vibrant nature of this sector resulting in negative outcomes such as lower commitment. The objective of this study is to know whether faculty of private sector universities in Pakistan experience $\mathrm{PCB}$, and if yes, what impact does it have on their Job Satisfaction, Affective Commitment and OCB. This study will guide the management of universities to keep their promises, because if psychological contract is breached, it will lead to lower performance and attendance (Rousseau, 1995) on the part of the teachers.

\section{REVIEW OF LITERATURE}

\section{Psychological Contract Breach and Employees Outcomes}

Psychological Contract Breach is the perception of one party in an exchange relationship who feels that the promises made by the other party have not been met. Rousseau (1995) defined Psychological Contract as an exchange relationship between the employees and the organization related to an agreement developed by the organization. When employees perceive that there is a mismatch between their expectations and what the company has actually delivered, they experience PCB (Restubog, Bordia, Krebs \& Tang, 2005). PCB is mostly viewed as an under fulfillment of the psychological contract, but some researcher also emphasized on the over fulfillment of the Psychological Contract as well (Turnley, Bolino, Lester \& Bloodgood, 2003; Lambert, Edwards \& Cable, 2003).

There is a differencebetween PCB and Psychological Contract Violation (PCV). According to Henderson and O’ Leary Kelly (2012), PCB is an individual cognition about the organizational failure to fulfill its one or more obligations, while the intensity of emotional reactions to Psychological Contract Breach is known as PCV. So it is inferred from this differentiation that PCV is the outcome of PCB. Zhao et al. (2007) used PCV as a mediator between PCB and different outcomes. Psychological Contract breach is a unique concept, and not the same as unmet expectations, as proved by Zhao et al., 2007. He also found that breach predicts outcomes more strongly that unmet expectations.

A number of researchers have established negative relationship between PCB and employee's attitudes and behaviors. Psychological Contract Theory states that employees show negative responses to the failure of the organization to fulfill its obligations (Paille \& Dufour, 2013). Cantisano, Dominguez and Depolo (2008) conducted a study in which they identified and tested certain individuals and organizational level outcomes of PCB. They proved negative impact of PCB on Job Satisfaction, Organizational Commitment; performance, trust and $\mathrm{OCB}$, and a positive impact on turnover intensions and neglect in role duties. Similarly Zhao et al. (2007) found reduced employees' commitment, satisfaction, OCB and performance. Social Exchange Theory is the best framework for understanding employee's responses resulting from breach of psychological contract (Turnley et al., 2003). Some researchers have used AET to describe the process of PCB and its influence on work related outcomes (Weiss \& Cropanzano, 1996;Zhao et al., 2007).

Based on the above literature, researchers have related $\mathrm{PCB}$ with both positive and negative outcomes, but in this study PCB will be discussed in relation with three positive aspects of employee's outcomes, that are OCB, Effective commitment and Job Satisfaction.

Organ (1988) defines OCB as, "individual behavior that is discretionary, not directly or explicitly recognized by the formal reward system, and that in the aggregate promotes the effective functioning of the organization". OCB is not the formal requirement of 
one's job, such that the employees are not bound to display such behaviors (Zhao et al., 2007). The two common form of OCB are Organizational Citizenship Behavior-Individual (OCB-I) and Organizational Citizenship Behavior-Organization (OCB-O). OCB-I benefits other employees in the organization, while OCB-O benefits the organization. Most of the times, OCB is affected whenever psychological contract is met or unmet. Consistent with the Social Exchange theory, they found that OCB-O is more strongly related to PC fulfillment than OCB-I (Turnley et al., 2003). Organ (1988) identified five dimension of OCB, namely altruism, civic virtue, conscientiousness, courtesy and sportsmanship (Mohammad, Habib \& Alias, 2011). In this study we will measure all these dimensions of OCB.

An empirical study concluded a egative relationship between PCB and both OCB-I and OCB-O (Restubog, Hornsey, Bordia \& Esposo, 2008). An empirical study conducted by Chen, Tsui and Zhong (2008) emphasized on both the PCB of employees by employers and PCB of employer by employees. They found that PCB of employees is negatively related to Organizational Commitment, OCB and work performance. In the same study, Chen et al. (2008) examined and proved a weaker relationship between PCB of more traditional employees and negative outcomes, as compared to less traditional employees. Restuboget al. (2008) found that PCB negatively influences employee's trust in the organization that causes employee to dis-identify from the organization, subsequently refraining employees to involve in OCB. Aligned with Social Exchange theory, when organization breaches the contract by showing unhelpful behaviors, employees reciprocate it by abandoning to show OCB (Hornsey, 2008). Another study found a positive relationship between PC fulfillment and OCB. This study, conducted by Chen and Kao (2011), revealed that when students in a police academy perceive PC fulfillment, they showed service oriented OCB.

Affective Commitment is one of the construct of Organizational Commitment. Organizational Commitment is a bond between an individual and its organization (Camilleri \& Heijden, 2007). Meyer and Allen (1991) identified three components of Organizational Commitment; that are Affective Commitment, continuance commitment and normative commitment. This study will include only Affective Commitment, because this component of commitment is strongly related to emotional attachments (Snyder \& Cistulli, 2011; Parzefall \& Kuppelwieser, 2012). Affective Commitment is defined as, "employee's emotional attachment to, identification with, and involvement in the organization" (Meyer \& Allen,
1991). It is an emotional bond between employees and their organization (Rhoades, Eisenberger \& Armeli, 2001). According to Meyer and Allen (1991),Affective Commitment is employee's emotional attachment to the organization; antecedents to whichareWork Experiences, Personal Characteristics and Organizational Structure. They found that work experience is the main thing that leads to good feelings and personal competence. Affective Commitment is a psychological state, solely experienced by individuals and built on the cognition of a rewarding relationship (Lovblad, Hyder \& Lonnstedt, 2012). It is a psychological bond that glues an employee with its organization ( Ngo, Loi, Foley, Zheng \& Zhang, 2013).

When employees realize that their organization has breached their psychological contract, it lowers their trust in the organization, and leads to a lower commitment towards the organization as employees reciprocate in the exchange process (Guerrero, Bentein \& Lapalme, 2013). There is a negative link between the PCB and Organizational Commitment (Zhao et al., 2007). Synder and Cistulli (2011) also found a negative relationship between Psychological Contract Violation and Affective Commitment. Raja et al. (2004) found that PCB negatively affects the Affective Commitment of employees.

According to Knights and Kennedy (2005), "Job Satisfaction is an attitudinal variable that reflects how people feel about their jobs". It is an individual's positive or negative evaluation of his/ her job or job situation (Weiss \& Cropanzano, 1996). Job Satisfaction produces happy employees. (Haroon, Fakhar \& Rehman, 2012)

Job Satisfaction is widely debated and researched constructively (Falkenburg \& Schyns, 2007). There are many attitudes of employees towards their jobs, but Job Satisfaction is the most important employee's attitude (Saari \& Judge, 2004). According to Weiss and Cropanzano (1996), events that are emotionally charged have an impact on Job Satisfaction. As PCB is also an emotional event, therefore, it is inferred that it also effect Job Satisfaction. PCB is negatively related to Job Satisfaction (Zhao et al. 2007).Raja et al. (2004) found a negative relationship between PCB and Job Satisfaction. Another empirical study showed that PCB of younger employees in comparison with old aged employees is strongly related to Job Satisfaction (Bal, Lange, Jansen \& Velde, 2013). Lambert et al. (2003) found that when employees receive more inducements than promised, they show more satisfaction. On the basis of above discussion, it is hypothesized that:

Hypothesis 1. There is a negative relationship between $P C B$ and $O C B$. 
Hypothesis 2. There is a negative relationship between PCB and Affective Commitment of employees.

Hypothesis 3. There is a negative relationship between the PCB and Job Satisfaction.

\section{Psychological Capital and Employees' Outcomes}

In recent years, Psychological Capital is the focus of positive organizational behavior (POB), which endures to improve the positive aspects of employees (Abbas \& Raja, 2011).It is the derivative of POB (Avey, Luthans \& Jensen, 2009). A comprehensive definition of Psychological Capital is, "An individual's positive psychological state of development and is characterized by: (1) having confidence (self-efficacy) to take on and put in the necessary effort to succeed challenging tasks; (2) making a positive attribution (optimism) about succeeding now and in the future; (3) persevering toward goals and, when necessary, redirecting paths to goals (hope) in order to succeed and (4) when beset by problems and adversity, sustaining and bouncing back and even beyond (resilience) to attain success)" (Luthans, Avolio, Avey, \& Norman, 2007: p. 3).Psychological Capital shows the level of hope, resilience, confidence and optimism of any employee (Sridevi \& Srinivasan, 2012). Chen and Lim (2012) refer it as a psychological well-being. Psychological Capital is a core construct with four facets of hope, optimism, resilience and self-efficacy, which were measured and validated both individually and collectively (Luthans et al. 2007). They found that the four facets of Psychological Capital, all collectively give better outcomes that individual facets. Based on this result, inclusion criteria of this study with respect to Psychological Capital is to take Hope, Optimism, Resilience and Self-efficacy, combined as core components of Psychological Capital. Based on prior work, Luthans, Norman, Avolio and Avey, (2008) suggested that Psychological Capital is not a definite personality trait and can be changed with experience and training. There was a change in the Psychological Capitallevel of respondents over time in a study carried out by Peterson, Luthans, Avolio, Walumbwa, and Zhang (2011). Psychological Capital has a significant contribution resulting in a number of workplace outcomes (Luthans et al., 2008).

Many studies supports that Psychological Capital has a positive relationship with OCB. A Meta analytical study by Avey, Reichard, Luthans and Mhatre (2011) revealed that employees high on Psychological Capital show positive behaviors such as OCB and is negatively related to deviance. However, one study shows no significant relationship between Psychological Capital as a core construct and OCB across private and public sector organization (Shahnawaz \& Jafri, 2009). Norman, Avey, Nimnicht, and Pigeon (2010) found a positive link between Psychological Capital and OCB directed towards organization, and a negative association between Psychological Capital and deviance. Almost the same results were found by Avey, Wernsing, and Luthans (2008). A positive relationship between Psychological Capital and OCB both directed to individuals and organization was found in the study by Avey, Luthans, and Youssef (2010).

Many researchers proved a positive relationship between Psychological Capital and employees' commitment. For example Avey et al. (2011) found a significant relationship between Psychological Capital and Employees' commitment - a positive attitude. Etebarian Tavakoli, \& Abzari, (2012) found interesting results on Psychological CapitalOrganizational Commitment relationship. They found that Psychological Capital was significantly related only to emotional or Affective Commitment and no other forms of commitment. Luthan et al. (2011) conducted and found a positive relationship between Psychological Capital and Organizational Commitment, controlling some variables such as conscientiousness, extraversion and self-evaluation. One study by Shahnawaz and Jafri (2009) opposes that favorable relationship between Psychological Capital as a whole, of its components and commitment.

Luthan et al. (2008) found a positive relationship between Psychological Capital and satisfaction of employees working in services firms and a high-tech manufacturing companies. The similarity between leaders and subordinates' Psychological Capital level leads to perceived Job Satisfaction (Larson, Norman, Hughes, \& Avey, 2013). Luthans et al. (2007) identified a positive relationship between Psychological Capital with all its components (Self-efficacy, Hope, Optimism and Resilience) and Job Satisfaction. They also found that each component individually was not as much a good predictor of Job Satisfaction compared to all components as a whole. In a Meta analytical study conducted by Avey et al. (2011), they established a relationship between Psychological Capital and desirable and undesirable behaviors, and found that employees with high Psychological Capital are more satisfied with their jobs. If there is a similarity between leaders and followers' level of Psychological Capital, Employees' Engagement with the organization will be more, which subsequently leads to employees' Job Satisfaction (Larson et al., 2013). On the basis of above discussion, it is hypothesized that:

Hypothesis 4. There is a positive relationship between Psychological Capital and OCB. 
Hypothesis 5. There is a positive relationship between Psychological Capital and Affective Commitment

Hypothesis 6. There is a positive relationship between Psychological Capital and Job Satisfaction.

\section{The Moderating Role of Psychological Capital}

As mentioned earlier, Psychological Capital has not been used as a moderator between PCB and positive employee's outcome so far, but in the preceding section, an attempt is made to build up this relationship based on past relevant studies and logic. As discussed earlier, (See Introduction) PCB is an affective event that results in negative outcomes, and this notion is aligned with Affective Event Theory (Weiss \& Cropanzano, 1996). The accumulation of frequent small events rather than one single event may develop the perception of breach among employees (Parzefall \& Coyle-Shapiro, 2011). In the above discussion on Psychological Capital, it is clear that Psychological Capital is not a fixed trait, but is subject to change over time. So it is inferred, that the change in the level of Psychological Capital will change the magnitude of accumulated events that caused PCB. So employees high on Optimism (a component of Psychological Capital) will show lesser counter reactions, because such employees perceive negative events as temporary, situation-specific and external (Seligman, 1998) as cited by Sridivi and Srinivasan (2012). PCB is a negative and adverse situation. Resiliency is the psychological capability of a person to come back to his or her original state from adverse and negative situations (Luthans, 2002). So, it is inferred that resiliency, when combined with PCB will lessen negative employee's outcomes. Hope, as a component of Psychological Capital enables employees to choose alternative ways of achieving goals; so whenever employees experience a breach, employees high on hope may think of alternative ways as opposed to counter behaviors to combat with negative situations. Riolli, Savicki, and Richards (2012) found in a study that Psychological Capital enrich students with mental power to tackle negative situations. They concluded that Psychological Capital reduces the impact of stress on negative outcomes. Based on this, it is analogized that Psychological Capital reduces the strength of relationship between PCB (because stress is also negative phenomenon as $\mathrm{PCB}$ ) and employees outcomes.

Based on the above discussion, following hypotheses are developed:

\section{Hypothesis 7. Psychological Capital will}

moderate the relationship between $P C B$ and $O C B$

Hypothesis 8. Psychological Capital will moderate the relationship between $P C B$ and Affective Commitment.

Hypothesis 9. Psychological Capital will moderate the relationship between $P C B$ and Job Satisfaction.

FIGURE 1 Conceptual Model

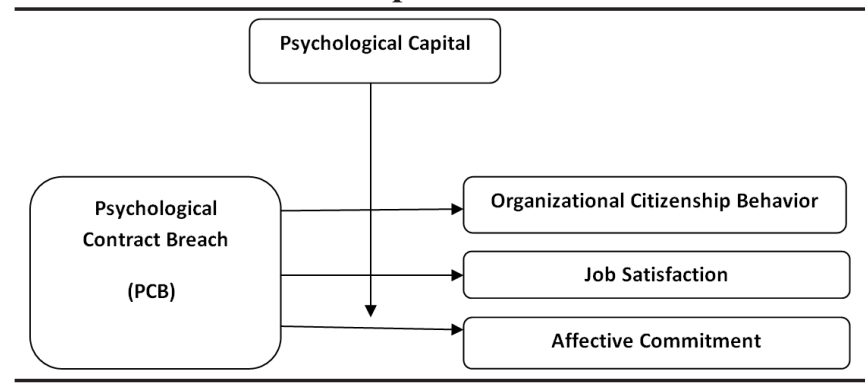

METHODOLOGY

\section{Population and Sample}

Based on convenient sampling, a total of 190 selfadministered questionnaires were distributed among the teaching faculty of private sector universities of KPK. The collection of data from private sector universities' teachers is based on the rationale, that in Pakistan, these universities are more functional in research activities and give better output. Moreover, data collection from this sector is relatively easy and convenient. Out of 190 questionnaires, 145 were received, of which only 128 were considered for analysis with a response rate of $67 \%$. While administering the questionnaires, the respondents were assured that their names will be kept secret and the data will be used only for this project.

\section{Demographic Characteristics}

The respondents had a mean age of $31(\mathrm{~s} . \mathrm{d}=5.63)$ and $79.7 \%$ were male. Mean experience of the employees with their current university was 4.4 ( $\mathrm{s} . \mathrm{d}=3.6)$. Most of the respondents $(78 \%$ ) were lecturers, and the rest were Assistant Professors. The qualification of the respondents ranged from Masters to Ph.D; 66\% respondents were Masters.

\section{Measures}

All the study variables were measured on a 5 point Likert scale from Strongly Disagree $=1$ to Strongly Agree $=5$.

Psychological Contract Breach was measured using 5-itmes scale developed by Robinson and Morrison (2000). One sample item is, "My employer has broken many of its 
promises to me, even though, I have upheld my side of the deal". The Cronbach's alpha of the scale was 0.72 .

Organizational Citizenship Behavior was measured using 20-itmes scaled developed by Podsakoff and Mac Kenzie (1989). One sample item is, "I help orient new people even though it is not required". The Cronbach's alpha of the scale was 0.88 .

Job Satisfaction was measured using 6-items version by Agho, Price and Mueller (1992). One sample item is, "I find real enjoyment in my work". To improve the Cronbach's alpha, the scale was reduced to 5-itmes after which the Cronbach's alpha of the scale was 0.74 .

Affective Commitment was measured using 8-itmes scales developed by Meyer and Allen (1997). One simple item is, "I enjoy discussing my organization with people outside of it". The Cronbach's alpha of the scale was 0.83 .

Psychological Capital was measured using a 24 items scale developed by Luthans, Youssef and Avolio (2007). One sample item of the scale is, "I always look on the bright side of things regarding my job". The Cronbach's alpha of the scale was 0.90 .

\section{Control Variables}

One way ANOVAwas performed to control for variations in dependent variable(s). The results revealed that there were differences in $\mathrm{OCB}(\mathrm{F}=3.952, \mathrm{p}<.001), \mathrm{AC}(\mathrm{F}=3.108$, $\mathrm{p}<.001)$ and JS $(\mathrm{F}=4.534, \mathrm{p}<.05)$ across age. Thus, age was controlled in the regression analysis. Similarly, there were significant differences in $\mathrm{OCB}(\mathrm{F}=2.186, \mathrm{p}<.05)$ and JS $(\mathrm{F}=2.084, \mathrm{p}<.05)$ across experience. Hence experience was also controlled in regression analysis. Significant differences were found in $\mathrm{AC}(\mathrm{F}=5.035, \mathrm{p}<.05)$ across educational levels, so, education was also controlled in regression analysis.

\section{RESULTS}

Table 1 shows the descriptive statistics and correlation among variables. All correlations are significant at $\mathrm{p}<.001$. The mean value for PCB was 2.66 (s.d. $=0.76$ ). The bivariate associations presented in the correlation matrix provide provisional support for $\mathrm{H} 1$, $\mathrm{H} 2, \mathrm{H} 3, \mathrm{H} 4, \mathrm{H} 5$ and H6. There was negative correlation between PCB and OCB ( $\mathrm{r}=-0.48, \mathrm{p}<.001), \mathrm{PCB}$ and $\mathrm{AC}(\mathrm{r}=-0.54, \mathrm{p}<.001)$ and PCB and JS $(\mathrm{r}=-0.61, \mathrm{p}<.001)$ which provisionally support first three hypothesis. The correlation between Psychological Capital and employees' outcomes was also significant and positive. The correlation between Psychological Capital and OCB $(\mathrm{r}=.78, \mathrm{p}<.001)$, Psychological Capital and AC $(\mathrm{r}=.56, \mathrm{p}<.001)$ and Psychological Capital and JS $(\mathrm{r}=.61$, $\mathrm{p}<.001)$; all these correlations provisionally support $\mathrm{H} 4$, $\mathrm{H} 5$ and $\mathrm{H} 6$ respectively.

TABLE 1

Means, Standard Deviations, Correlations and Reliabilities

\begin{tabular}{lccccccc}
\hline Variable & Mean & SD & $\mathbf{1}$ & $\mathbf{2}$ & $\mathbf{3}$ & $\mathbf{4}$ & $\mathbf{5}$ \\
\hline 1. PCB & 2.66 & 0.76 & -0.72 & & & & \\
2. OCB & 3.85 & 0.53 & $-.48^{* * *}$ & -0.88 & & & \\
3. AC & 3.56 & 0.72 & $-.54^{* * *}$ & $0.59^{* * *}$ & -0.83 & & \\
4.JS & 3.64 & 0.7 & $-.61^{* * *}$ & $0.62^{* * *}$ & $0.69^{* * *}$ & -0.74 & \\
5. Psychological Capital & 4.37 & 0.61 & $-.48^{* * *}$ & $0.78^{* * *}$ & $0.56^{* * *}$ & $0.61^{* * *}$ & -0.9 \\
\hline
\end{tabular}

$n=128$; alpha reliabilities are given in parenthesis. For male ' 0 ' and female ' 1 '; education ranges from 1 to 3, designation from 1 to 4 . For ***.correlations, $p<.001$.

\section{Regression Analyses}

Regression analyses were performed to formally test the entire hypothesis. In all regression analysis, control variables were entered in the first step. In the second step, independent variable and IWE were entered to check its individual impact on dependent variables. In the third step, interaction term (PCB x Psychological Capital) was entered to predict its combined effect on dependent variables.

TABLE 2

Results of Regression Analysis for outcomes and Moderator

\begin{tabular}{|c|c|c|c|c|c|c|c|c|c|}
\hline \multirow[b]{2}{*}{ Predictors } & \multicolumn{3}{|c|}{ OCB } & \multicolumn{3}{|c|}{$\mathbf{A C}$} & \multicolumn{3}{|c|}{ JS } \\
\hline & $\beta$ & $\mathbf{R}^{2}$ & $\Delta \mathbf{R}^{2}$ & B & $\mathbf{R}^{2}$ & $\Delta \mathbf{R}^{2}$ & $\beta$ & $\mathbf{R}^{2}$ & $\Delta \mathbf{R}^{2}$ \\
\hline $\begin{array}{l}\text { Step } 1 \\
\text { Control Variables } \\
\text { Step } 2\end{array}$ & & 0.004 & & & 0.026 & & & 0.092 & \\
\hline Main effect & & & & & & & & & \\
\hline PCB & $-0.09 *$ & 0.643 & $0.639^{*}$ & $-.363 * * *$ & 0.48 & $0.45^{* * *}$ & $-0.428 * * *$ & 0.59 & $0.50 * * *$ \\
\hline $\begin{array}{l}\text { Psychological Capital } \\
\text { Step } 3\end{array}$ & $.64 * * *$ & 0.643 & $.639 * * *$ & $.499 * * *$ & 0.48 & $0.45 * * *$ & $0.422 * * *$ & 0.59 & $0.50 * * *$ \\
\hline PCBxPsychological Capital & $.127 *$ & 0.657 & $0.014^{*}$ & $0.138^{\mathrm{ns}}$ & 0.49 & 0.009 & $0.120^{\mathrm{ns}}$ & 0.597 & 0.007 \\
\hline
\end{tabular}


$n=128$; control variables are age, experience and education. ${ }^{n s} p<.01,{ }^{*} p<.05, * * p<.01, * * * p<.001$

As shown in Table 2, a significant negative relationship was found between PCB and OCB ( $\beta=$ $-.09, \mathrm{p}<.05)$ which supported hypothesis 1 . There was a significant negative relationship between PCB and $\mathrm{AC}(\beta=-.363, p<.001)$ which supported hypothesis 2 . Similarly a significant negative relationship was proved between PCB and JS $(\beta=-.428 p<.001)$. Hypothesis 4 , 5 and 6 predicted that there is a positive relationship between Psychological Capital-OCB, Psychological Capital-AC and Psychological Capital-JS respectively, which were all supported through results of regression analysis. A significant positive relationship was found between Psychological Capital and OCB $(\beta=.64$, $\mathrm{p}<.001)$, Psychological Capital and $\mathrm{AC}(\beta=.499$, $\mathrm{p}<.001)$ and Psychological Capital and JS $(\beta=.422$, $\mathrm{p}<.001)$. The moderated regression analysis was performed to check the combined effect of PCB and Psychological Capital on employees' outcomes. The result shows that Psychological Capital moderated the relationship between PCB and OCB $(\beta=.127, \mathrm{p}<.05)$, which supported hypothesis 7 . No significant combined effect was found on Affective Commitment and Job Satisfaction as indicated by Table 2 . The interaction term and $\mathrm{AC}(\beta=.138, \mathrm{p}>.10)$ and interaction term and $\operatorname{JS}(\beta=.120, \mathrm{p}>.10)$, all these results showed no significant combined effect of PCB and Psychological Capital on Affective Commitment and Job Satisfaction which rejected $\mathrm{H} 8$ and $\mathrm{H} 9$ respectively.

\section{CONCLUSION \& DISCUSSION}

All hypotheses except two of this study were accepted. Hypothesis 1 predicted that there is a significantly negative relationship between PCB and OCB, which was supported by this study. This finding is aligned with previous studies of Restubog et al. (2007), Restubog, et al. (2008) and Chen et al. (2008). They also established and proved the same relationship. When employees perceive that their promises are not being met, they abandon exhibiting those activities that fall beyond the scope of their job. That's why PCB leads to reduce Organizational Citizenship Behaviors.

The finding of the study that PCB has a significant negative impact on Affective Commitment of employees also support the prior work of Guerrero et al. (2013), Zhao et al. (2007) and Raja et al. (2004). PCB is a negative attitude, while Affective Commitment is a positive attitude of employee, which means, both are contrary to each other. When employees experience PCB, their emotional attachment to organization reduces.

The third finding of the study also supports prior work of Lambert et al. (2003), Raja et al. (2004) and Zhao et al.( 2007).When there is PCB of employees, they show lower Job Satisfaction. Again, PCB results in harsh feelings, which negatively affect pleasant feelings one gets from his/her job.

The fourth finding was that those employees who were high in Psychological Capital, exhibited more Organizational Citizenship Behaviors. Although, OCBs are not compulsory for the employees, but those with high Psychological Capital hope for better reward in future, and they are optimistic that someday organization will reciprocate these behaviors. These findings are in accordance with previous research finding by Luthans et al. (2007), Luthan et al. (2008) and Larson et al., (2013).

The fifth findings also supported the hypothesis that Psychological Capital is positively related with Affective Commitment. This hypothesis is in line with previous studies of Luthan et al. (2011), Avey et al. (2011) and Etebarian et al. (2012). Affective Commitment is the emotional attachment of an employee with his or her organization. Emotional attachment in other words also means a long term commitment. So, employees high on Psychological Capital hope for a better future of self as well as the organization, and even if sometimes they become negatively charged with emotions, they still have the confidence and capability to cope with this situation or bounce back. So employees with greater Psychological Capital have long term commitment and emotional attachment with the organization.

The sixth finding was a positive relationship between Psychological Capital and Job Satisfaction. This result also provided support to previous research finding of Luthans et al. (2007), Luthan et al. (2008), Avey et al. (2011) and Larson et al., (2013). This finding implies that employee's high on Psychological Capital accepts and prefers challenging tasks, and are confident of their success as they are assured that if any mishap occurs, they can quickly return to their original psychological state. So, when they perform their job, they enjoy it and feel pleasure. For those employees, job becomes a means of satisfaction and inspiration.

The results also supported the seventh hypothesis of the study that Psychological Capital moderated the relationship between PCB and OCB. These finding shows that when Psychological Capital is high, it reduces the negative impact of $\mathrm{PCB}$ on organizational citizenship behaviors. When faced with negatively charged emotions, employees high on Psychological Capital will not abandon extra-role behaviors in the hope that the situation will eventually settle soon. They also look at the bright side of the picture, and ignore irresponsible behavior by the organization.

Contrary to hypothesis 8 and 9, the result showed 
no moderating effect of Psychological Capital on PCBAffective Commitment and PCB-Job Satisfaction. The most obvious reason for this finding is that when employees frequently experience breach, than after a certain level their psychological resources diminishes. Psychological Capital is not a fixed trait; rather, it keeps on changing. So, even those employees who are high on Psychological Capital, gradually lose their psychological resources, and if appropriate measures are not taken to reimburse them with these resources, they find no more pleasure and satisfaction in their job, and ultimately their emotional attachment with the organization reduces.

\section{Implications for managers}

This study has some implications for the managers, as employees' psychological contract is mostly developed through information received from the organization and interaction with its agents, so, managers should take measure which results in identifiable PC of employees. Managers should take initiative that can reveal what the employees perceive about the organization's obligations. During selection process, applicants should be tested on their Psychological Capital, and those applicants should be preferred who are high on Psychological Capital. As Psychological Capital can be developed, organizations should take measures such as training and counseling to increase the Psychological Capital of the employees.

\section{Limitations and directions for future research}

This study has several limitations. The results of the study cannot be generalized because of inconvenient sampling technique and small sample size. Future researchers should use a more rigorous sampling technique and a larger sample size. The data is not the true representative of the population, because it pertains only to Lecturers and Assistant Professors of the universities, and no response was obtained from Associate Professors and Professors. Future studies should ensure data collection from teachers of all levels in the universities. Common method bias is another limitation to this study as OCB is a behavior, and it has been self-reported in this study. Future studies should focus on supervisor reported and peer reported data as well. Most of the variables were measured on 5-Likert scale, and data on all variables was collected at the same point in time from the respondent which also led to common method bias. To overcome this limitation, future researchers should measure different variables on different Likert scale so as to break the thought flow of respondents while filling questionnaires. As this research pertains only to private sector universities' teachers, future research should replicate this research across public sector universities as well and make a comparison between public sector and private sector universities' teachers.

\section{REFERENCES}

Abbas, M., \& Raja, U. 2011.Impact of Psychological Capital Innovative Performance and Job stress. 15th International Business Research Conference (Ref No. 449). Melbourne, Australia: World Business Institute, Australia.

Agho, A. O., Price, J. L., \& Mueller, C. W. 1992. Discriminant validity of measures of job satisfaction, positive affectivity and negative affectivity. Journal of Occupational and Organizational Psychology, 65(3), 185-195.

Avey J. B., Luthans, F. \& Jensen, S. M. 2009. Psychological Capital: A Positive Resource for Combating Employee Stress and Turnover. Human Resource Management, 48(5), 677-693.

Avey, J. B., Luthans, F., \& Youssef, C. M. 2010.The additive value of positive Psychological Capital in predicting work attitudes and behaviors. Journal of Management,36(2), 430-452.

Avey, J. B., Reichard, R. J., Luthans, F., \& Mhatre K. H. 2011.Meta-Analysis of the Impact of Positive Psychological Capital on Employee Attitudes, Behaviors, and Performance. Human Resource Development Quarterly, 22(2), 127-152.

Avey, J. B., Wernsing, T. S., \& Luthans, F. 2008. Can positive employees help positive organizational change? Impact of Psychological Capital and emotions on relevant attitudes and behaviors. The Journal of Applied Behavioral Science, 44(1), 4870.

Bal, P. M., Lange, A. H., Zacher, H., \& Heijden, B. V. 2013. A lifespan perspective on psychological contracts and their relations with Organizational Commitment. European Journal Of Work and Organizational Psychology, 22(3), 279-292

Bal, P.M., Chiaburu, D. S., \& Diaz, I. 2011. Does Psychological Contract Breach Decrease Proactive Behaviors? The Moderating Effect of Emotion Regulation. Group \& Organization Management, 36(6), $722-758$

Bal, P.M., Chiaburu, D. S., \& Jansen, P. G. W. 2010. Psychological Contract Breach and Work Performance: Is social exchange a buffer or intensifier. Journal of Managerial Psychology, 25(3), 252-273

Bal, P.M., Lange, A. H. D., Jansen, P. G. W., \& Van Der Velde, M.E. G. 2013. A Longitudinal Study of AgeRelated Differences in Reactions to Psychological Contract Breach. Applied Psychology: An International Review, 62(1), 157-181. 
Bao, Y., Olson, B., Parayitam, S. \& Zhao, S. 2011. The effects of psychological contract violation on Chinese executives. The International Journal of Human Resource Management, 22(16), 33733392

Bashir, S., \& Nasir, M. 2013.Breach of psychological contract, organizational cynicism and union commitment: A study of hospitality industry in Pakistan. International Journal of Hospitality Management, 34, 61-65

Blau, P. M. 1964. Exchange and power in social life. Transaction Publishers.

Brown, L.A., \& Roloff, M.E. 2011. Extra-role Time, Burnout, and Commitment: The Power of Promises Kept. Business Communication Quarterly,74(4), 450-474

Camilleri, E., \& Heijden, B. I. V. D. 2007. Organizational Commitment, public service motivation, and performance within the public sector. Public Performance \& Management Review, 31(2), 241274.

Cantisano, G. T., Dominguez, J. M., \& Depolo, M. 2008. Psychological contract breach and outcomes: Combining meta-analysis and structural equation model. Psicothema, 20(3), 487-496.

Chambel, M. J., \&Alcover, C. M. 2011.The psychological contract of call-centre workers: Employment conditions, satisfaction and civic virtue behaviours. Economic and Industrial Democracy, 32(1), 115134

Chao, J. M. C, Cheung, F. Y. L, \& Wu, A. M. S. 2011. Psychological contract breach and counterproductive workplace behaviors: testing moderating effect of attribution style and power distance. The International Journal of Human Resource Management, 22(4), 763-777

Chen, C. V., \& Kao, R. H. 2011. Work Values and ServiceOriented Organizational Citizenship Behaviors: The Mediation of Psychological Contract and Professional Commitment: A Case of Students in Taiwan Police College. Soc Indic Res, 107, 149169.

Chen, D. J. Q., \& Lim, V. K. G. 2012. Strength in adversity: The influence of Psychological Capital on job search. Journal of Organizational Behavior, 33, 811-839.

Chen, Z.X., Tsui, A.S., \& Zhong, L. 2008. Reactions to psychological contract breach: a dual perspective. Journal of Organizational Behavior, 29, 527-548.

Etebarian, A., Tavakoli, S., \& Abzari, M. 2012.The relationship between Psychological Capital and Organizational Commitment. African Journal of Business Management, 6(14), 5057-5060.

Falkenburg, K., \& Schyns, B. 2007. Work satisfaction,
Organizational Commitment and withdrawal behaviours. Management Research News, 30(10), 708-723.

Gerber, M., Grote, G., Geiser, C., \& Raeder, S. 2012. Managing psychological contracts in the era of the "new" career. European Journal of Work and Organizational Psychology, 21(2), 195-221

Guerrero, S., Bentein, K., \& Lapalme, M. E. 2013. Idiosyncratic Deals and High Performers 'Organizational Commitment. Journal of Business Psychology, DOI: 10.1007/s10869-013-9316-7.

Haroon, M., Fakhar, Z. H. M., \& Rehman, W., 2012. The Relationship between Islamic Work Ethics and Job Satisfaction in Healthcare sector of Pakistan. International Journal of Contemporary Business Studies, 3(5), 6-12.

Henderson, K. E., \& O'Leary-Kelly, A. M. 2012. When Broken Promises Threaten One's Identity: The Impact of Psychological Contract Breach on Self-Identity Threat. Journal of Organizational Psychology, 12 (3/4), 81-98.

Hornsey, M. J. 2008. Social identity theory and selfcategorization theory: A historical review. Social and Personality Psychology Compass, 2 (1), 204222.

Jamil, A., \& Raja, U. 2013.Psychological Contract Types as Moderator in the Breach-Violation and Violation-Burnout Relationships. The Journal of Psychology, 147(5), 491-515

Kickul J. 2001. When Organizations Break Their Promises: Employee Reactions to Unfair Processes and Treatment. Journal of Business Ethics, 29, 289-307

Knights, J.A., Kennedy, B. J. 2005.Psychological Contract Violation: Impacts on Job Satisfaction and Organizational Commitment Among Australian Senior Public Servants. Applied H. R. M. Research, 10(2), 57-72.

Lambert, L. S., Edwards, J. R., \& Cable, D. M. 2003. Breach and fulfillment of the psychological contract: A comparison of traditional and expanded views. Personnel Psychology, 56(4), 895-934.

Lange, A.H., Bal, P.M., Heijden, B.V., Jong, N., \& Schaufeli, W. B. 2011. When I'm 64: Psychological contract breach, work motivation and the moderating roles of future time perspective and regulatory focus. Work and Stress, 25(4), 338-354

Larson, M. D., Norman, S. M., Hughes, L. W., \& Avey J. B. 2013. Psychological Capital: A New Lens for Understanding Employment fit and Attitude. International Journal of Leadership Studies, 8(1), 28-43.

Lovblad, M., Hyder, A.S., \& Lonnstedt, S. 2012. Affective Commitment in industrial customer-supplier 
relations: a psychological contract approach. Journal of Business \& Industrial Marketing, 27(4), 275-285.

Luthans, F. (2002). The need for and meaning of positive organizational behavior. Journal of Organizational Behavior, 23(6), 695-706.

Luthans, F., Avolio, B. J., Avey, J. B., \& Norman, S. M. 2007. Positive Psychological Capital: Measurement and relationship with performance and satisfaction. Personnel Psychology, 60, 541-572.

Luthans, F., Norman, S. M., Avolio, B. J., \& Avey, J. B. 2008.The mediating role of Psychological Capital in the supportive organizational climateemployee performance relationship. Journal of Organizational Behavior, 29, 219-238.

Luthans, F., Youssef, C. M., Avolio, B. J. 2007. Psychological Capital. New York: Oxford University Press.

Meyer, J. P., \& Allen, N. J. 1997. Commitment in the workplace: Theory, research, and application. Sage.

Meyer, J.P., \& Allen, N. J. 1991.A three component conceptualization of Organizational Commitment. Human Resource Management Review, 1(1), 6189.

Mohammad, J., Habib, F. Q., \& Alias, M. A. 2011. Job Satisfaction and Organizational Citizenship Behaviour: An Empirical Study at Higher Learning Institutions. Asian Academy of Management Journal, 16(2), 149-165.

Morrison, E. W., \& Robinson, S. L. 1997.When employees feel betrayed: A model of how psychological contract violation develops. Academy of Management Review, 22(1), 226-256.

Ngo, H. Y., Loi, R., Foley, S., Zheng, X., \& Zhang, L. 2013. Perceptions of organizational context and job attitudes: The mediating effect of organizational identification. Asia pacific journal of management, 30(1), 149-168.

Norman, S. M., Avey, J. B., Nimnicht, J. L., \& Pigeon, N. G. 2010.The interactive effects of Psychological Capital and organizational identity on employee organizational citizenship and deviance behaviors. Journal of Leadership \& Organizational Studies, doi:10.1177/1548051809353764.

Organ, D. W. (1988). Organizational citizenship behavior: The good soldier syndrome. Lexington Books/DC Heath and Com.

Paille, P. \& Dufour, M. E. 2013. Employee Responses To Psychological Contract Breach And Violation: Intentions To Leave The Job, Employer Or Profession. The Journal of Applied Business Research, 29(1), 205-216.

Parzefall, M. R., \& Kuppelwieser, V. G. 2012.
Understanding the antecedents, the outcomes and the mediating role of social capital: An employee perspective. Human relations, 65(4), 447-472.

Parzefall, M. R., \& Coyle-Shapiro, C. 2010.Making sense of psychological contract breach. Journal of Managerial Psychology, 26(1), 12-27

Peterson, S. J., Luthans, F., Avolio, B. J., Walumbwa, F. O., \& Zhang, Z. 2011.Psychological Capital and Employees Performance: A Latent Growth Modeling Approach. Personnel Psychology, 64, 427-450.

Podsakoff, P. M., \& MacKenzie, S. B. 1989. A second generation measure of organizational citizenship behavior. Unpublished manuscript, Indiana University, Bloomington.

Raja, U., Johns, G. \& Ntalianis, F. 2004.The impact of personality on psychological contracts. Academy of Management Journal, 47(3), 350-67.

Restubog, S. L. D., Bordia, P., Krebs, S. A., \& Tang, R. L. 2005.The role of leader-member exchange in the psychological contract breach-subordinates' performance relationship. Academy of Management Proceedings, No. 1, 11-16.

Restubog, S. L., Bordia, P., \& Tang, R. L. 2007. Behavioural Outcomes of Psychological Contract Breach in a Non-Western Culture: The Moderating Role of Equity Sensitivity. British Journal of Management, 18, 376-386.

Restubog, S. L., Hornsey, M. J., Bordia, P., \& Esposo, S. R. 2008. Effects of Psychological Contract Breach on Organizational Citizenship Behaviour: Insights from the Group Value Model. Journal of Management Studies 45(8), 1378-1400.

Rhoades, L., Eisenberger, R., \& Armeli, S. 2001. Affective Commitment to the Organization: The Contribution of Perceived Organizational Support. Journal of Applied Psychology, 86(5), 825-836.

Riolli, L., Savicki, V., \& Richards, J. 2012. Psychological Capital as a Buffer to Student Stress. Psychology, 13(12A), 1202-1207.

Robinson, S. L., \& Morrison, E. W. 2000. The development of psychological contract breach and violation: A longitudinal study. Journal of organizational Behavior, 21(5), 525-546.

Rousseau, D.M. 1995. The Psychological Contract: Violations and Modifications. Sage, Newburry Park.

Saari, L. M., Judge, T. A. 2004. Employee's attitude and Job Satisfaction. Human Resource Management, 43(4), 395-407.

Shahnawaz, M. G., \& Jafri, M. H. 2009. Psychological Capital as Predictors of Organizational Commitment and Organizational Citizenship Behaviour. Journal of the Indian Academy of Applied Psychology, 35, 
78-84.

Shahzad, K., Bashir, S., Ramay, M. I. 2008. Impact of HR Practices on Perceived Performance of University Teachers in Pakistan. International Review of Business Research Papers,4(2), 302-315

Snyder, J. L. \& Cistulli, M. D. 2011. The Relationship between Workplace E-Mail Privacy and Psychological Contract Violation, and Their Influence on Trust in Top Management and Affective Commitment. Communication Research Reports, 28(2), 121-129.

Sridevi, G., \& Srinivasan, P. T. 2012. Psychological Capital: A Review of Evolving Literature. Colombo Business Journal, 3(1), 25-39.

Turnley, W.H., Bolino, M. C., Lester, S. W., \& Bloodgood, J. M. 2003. The Impact of Psychological Contract Fulfillment on the Performance of In-Role and Organizational Citizenship Behaviors. Journal of
Management, 29(2), 187-206.

Wangithi, W. E., \& Muceke, N. J. 2012. Effect of Human Resource Management Practices on Psychological Contract in Organizations. International Journal of Business and Social Science, 3(19), 117-121

Weiss, H. M., \& Cropanzano R. 1996.Affective Event Theory: A theoretical discussion of the structure, causes and consequences of affective experiences at work. Research in Organizational Behavior, 18, 1-74.

Zagenczyk, T. J., Gibney, R., Kiewitz, C., \& Restubog, S. L. D. 2009.Mentors, supervisors and role models: do they reduce the effects of psychological contract breach? Human Resource Management Journal, 19(3), 237-259.

Zhao, H., Wayne, S. J. Glibkowski, B. C., \& Bravo, J. 2007. The Impact of Psychological Contract Breach on Work-Related Outcomes: A Meta Analysis. Personnel Psychology, 60, 647-680. 


\title{
EFFECT OF EMOTIONAL INTELLIGENCE AND FINANCIAL LITERACY ON INVESTMENT DECISION MAKING WITH A MEDIATING ROLE OF RISK PERCEPTION
}

\author{
SAHAR PERVEZ \\ Mohammad Ali Jinnah University, Islamabad, Pakistan
}

\begin{abstract}
This research paper examines the impact of emotional intelligence and financial literacy on investment decision with a mediating role of risk perception. The data is collected by using questionnaire, from a sample of 152 investors, from stock exchange and banks. The results support that to make adequate investment decisions, investors should be financially literate and have control on their emotions. However, risk perception of investors does not mediate this relationship.
\end{abstract}

\section{INTRODUCTION}

To be a better decision maker one should have control over his emotions. According to Hess and Bacigalupo (2011) while making worth full decisions, conflicts often arise, this can have a negative impact on some constituency, even after conflicts are resolved. As individual give more preference to the things with which they are emotionally attached (Leary, Reilly, \& Brown, 2008). Decision makers who recognize and understand their emotions will effectively manage them in the process of decision making, and will be able to solve the conflicts arising in this process (Hess, \& Bacigalupo, 2011).

Killan (2012) explains emotional intelligence as the ability to perceive and identify emotions in one self and to manage it to enhance well-being and the quality of one's professional and personal relationships. Emotional intelligence is the ability to recognize emotions and connect them with beliefs in order to understand emotions and to regulate them (Wang, \& Wang, 2012).

Earlier it was considered that IQ factor is important for the enhancement of the person's ability to better manage things in a sophisticated way. The history of research on intelligence has proved that the success of an individual in his/her personal life and career depend not only on IQ but on other several factors as well. IQ is only the function of general intelligence (Derksen, Kramer, \& katzko, 2002). According to Matthews (2012), EQ factor is more significant than IQ factor in human dealings as IQ factor will not be able to determine several aspects of intelligence. EQ is a multidimensional construct which is related to IQ but they both have dissimilar qualities (Riggio, \& Reichard, 2008). Now the focus is more on EQ.
Keeping in view the concept of these researchers we can say that emotional intelligence enhance the personality of an individual and make him/her better at managing and arranging things which lead to building up an ability for accomplishing effective decision making. This ability of emotional intelligence not only enhances the processes of the decision making but also the outcome of the decision making. In an organization, decision maker who have self-awareness can make better decisions than other (Hess \& Bacigalupo, 2011). Like in other domains emotional intelligence has significant importance in making financial and investment decisions as well.

Emotional intelligence requires self-awareness, and self-awareness has a positive relationship with literacy level. Individuals who are more educated are more aware of their emotions and have control on their emotions, which help them to act appropriately in any intense situation and also in decision making process. To get fruitful outcomes in a particular field, an individual must have appropriate knowledge of that field to get a successful result of an investment; individual should have an awareness of the appropriate investment tool to end up with determined outcomes. Bohuslava, Csikova and Antosova, (2013) explain financial literacy as the ability to use skills, experience and knowledge of an individual in order to make an appropriate decision regarding the use and management of their own finances for long life financial security for themselves.

Financial literacy affects the investment decision process. Individuals who have more knowledge and awareness of financial tools and stock market behavior are more capable to perform better than those who have low or don't have knowledge of financial tools and market activities. As Rooij, Lusardi and Alessie (2011) report that 
the individuals who are not financially literate i.e. they are not aware of the working of stock market and are not familiar with stocks and bond, they keep themselves away from the stock market or they rely on the advice of friends and family while investing in stock market. Jappelli and Padula (2013) report that most adults have less knowledge about the basic concepts of economics and finance like risk diversification, inflation and interest component, due to which there are likely to be fewer chances to earn the required return.

Financial literacy increases the return of the investment. Consequently it is unblemished that financial literacy is positively related to investment decision. The relationship of financial literacy and investment decision making is affected by the risk perception of an individual. Investors, who are risk averse, hesitate to invest in risky assets. This statement indicates that investors who have risk aversive attitude favor diversification (Wang, Keller, $\&$ Siegrist, 2011). This evidence supports the traditional prospect theory. To avoid the risk aversive behavior, one should have knowledge of financial products and practically involve in investment processes.

There are limited studies available which examine the combine effect, of emotional intelligence and financial literacy on specifically, investment decision making. While making decisions about investment either at an organizational or individual level, one who has controls over his/her emotions and have knowledge of financial market tools, would efficiently accomplish and establish entities and make better decisions than others. So, there is a need of rigorous research to examine the relationship of emotional intelligence and investment decision making.

\section{REVIEW OF LITERATURE}

\section{Relationship of emotional intelligence and investment decision making}

Intelligence is an ability of an individual to manipulate and renovate information in to new concepts. Thorndike and Stein (1937) were the first ones who suggested the existence of social intelligence which they explained as the capability of individual to understand and manage people. According to them social intelligence helps individual to identify their own and others behavior and internal situations and thus act in a suitable manner. Social intelligence is the ability to understand people (Ladd, \& Chan, 2004). Social skills that are important components of social intelligence include the following abilities, the aptitude to express oneself in social dealings, the capability to "read" and comprehend different social circumstances, familiarity of social norms, personal problem-solving skills, and collective role-playing abilities (Riggio, \& Reichard,
2011). Earlier, social intelligence who considered as an important predictor to measure intelligence of individual, but the trend is now moving towards emotional intelligence. Now emotional intelligence is considered more important predictor to measure intellect than social intelligence. Emotional skills emphasis on how emotions are taken. Both IQ and EQ are constituted of different aptitudes (Riggio \& Reichard, 2011). The foundation of the concept of emotional Intelligence is the concept of social intelligence (Yunus, \& Hassan, 2012).

Salovey and Mayer (1990) were the first who gave the concept of emotional intelligence. According to them, emotional intelligence is competency of perceiving opinions and feelings of ourselves and others and distinguishing between these feelings in order to help in run individual's sentiments and actions. Their concept of emotional intelligence had to face a lot of criticism. Later Mayer and Salovey (1993) addressed these criticism in their paper as, to connect emotions with intelligence is not competent because emotions is less controversial area and would not able to measure the entire spectrum of intelligence which is a controversial area . They contempt this criticism as perceptive what other individual feel is a mental process, the way in which they addressed emotional intelligence is sequence of mental process and this abilities is a form of intelligence. Emotional intelligence vary among individuals, different people are less or more emotionally intelligent, some are more aware of their feelings than others and such awareness tend to make them regulate their own feelings effectively as well as others. Mayer and Salovey (1995) relate their concept of emotional intelligence with personality and clinical psychology. They developed three categories of emotional intelligent were emotional orientation, emotional involvement and emotional expertise. Afterwards Goleman (1995) broke down these dimensions into further five components which are self-awareness, self-management, selfmotivation, awareness of other's emotions, and handling relationships.

Self-awareness is the aptitude to comprehend the emotions that are affecting our sentiments and subconscious in mind and let us to act in a certain way (Quinn \& Wilemon, 2009).

Self-management is an aptitude to regulator one's emotions, and precludes one's self from acting on compulsion without taking consideration of thought versus an emotional reaction (Quinn \& Wilemon, 2009).

Self-motivation is an ability to control and motive oneself to be more productive.

Awareness of others emotions is an ability to understand other people action or behavior towards 
specific situation (Barling, Slater, \& Kelloway, 2000).

Handling relationships is an ability to manage the emotions of other individuals.

Different researchers defined emotional intelligence in different time periods. People who are good at linking thoughts to their feelings are rich in emotional intelligence; they have well understanding of theirs and others emotions as well (Mayer, \& Geher, 1996). Emotional intelligence is recognizing one's own and others' emotions and help in problem solving (Schutte et al, 1998; Insead, 1999) and contains the capability to understand the components; how they change, and reason about emotions consequently (Mayer, Caruso, \& Salovey, 2000). EI comprises of three distinct modules which are assessment and appearance of emotions, regulation of emotions and use of emotional information in acting and thinking (Petrides, \& Furnham, 2000). The ability to recognize emotion is one of the important component of emotional intelligence (Picard, Vyzas, \& Healey, 2001), and it is also helpful in predicting the social success (Der Zee, Thijs, \& Schakel, 2002). It is a determinant of real life consequences (Saklofske, Austin, \& Minski. 2003) and success (Alon \& Higgins, 2004). Emotional intelligence have four branches, perceiving emotions, using emotions to facilitate thought, understanding emotions, and managing emotions (Yan-hong, Runtian, \& Wang. 2009) and also identifies the relationship between feelings, thoughts and behavior (Ahangar, \& Rooshan, 2010). The concept of emotional intelligence comprises psychology and management of multiple features like emotional perception and understanding of emotions (Kangyin, \& Yujie, 2011) and improves the decision making process (Scott-Ladd \& Chan, 2004). Emotional intelligence is important in making rewarding outcome in decision making process. Those who are emotionally intelligent and have control on their emotions could enhance the ability to accomplish their work and understand the consequences of factors that affects the outcomes. According to Sevdalis, Petrides and Harvey(2007)decision-makers anticipate their emotions before making a decision they experience them when they receive the consequence of their decisions, and they recollection them from memory when they consider preceding decisions (good or poor). Emotional intelligence increases the confidence of individual which lead to positive outcomes (Gardner \& Stough, 2001). As in other domains, emotional intelligence is also a good representative of investment decision making and it considered as a significant tool in refining the effectiveness of individual in managing their interface with stakeholders (Quinn \& Wilemon, 2009). From the above evidences we can conclude that investors who are more emotionally intelligent have more probability of successful outcome of their investment decisions than those who are less emotionally intelligent.

\section{Hypothesis 1. Emotional Intelligence is positively related to Investment Decision Making.}

\section{Relationship between financial literacy and investment decision}

In our daily life, money has become an essential part, consciously or unconsciously. To be capable to earn money, save it, invest it and to familiarize oneself with financial products in market these days, each person should have financial knowledge (Zvarikova \& Majerova, 2013). Financial literacy is to have knowledge, confidence and skill to make effective financial decisions (Altman, 2012). There is a positive link between literacy and education level. The general education is strongly associated with financial literacy (Duca, \& Kumar, 2014). Educated people are able to understand the dynamics of financial market. With the development of financial markets, the need for financial literacy has become substantial (Marcolin \& Abraham, 2006). Individuals' financial knowledge and decision to participate in financial markets is greatly influenced by social interaction with colleagues, friends and family members. There is a greater effect of word-of-mouth communication because information tends to switch easily between geographically close beings (Bönte \& Filipiak, 2012).

There are several consequences of poor and good literacy of financial products. Rooij, Lusardi and Alessie (2007) found that individuals who have low literacy level are more likely to depend on their friends and family for financial advice, and less likely to participate in stock market. According to Lee, Yun and Haley (2012), investors with low financial knowledge were likely to give more consideration to advertised mutual fund as compare to those investors with low financial knowledge. The individuals who have poor financial literacy are probable to lack confidence when translating credit terms, and demonstrate confusion over financial concepts. They also hesitate to engage in activities which could help them to improve their awareness of the financial market (Gathergood, 2013). The income level leading to better educational training and work place activities affect the level of financial literacy of an individual (Al-Tamimi \& Kalli, 2009). Usually households have less literacy level; many of the households do not even know the basic difference of stocks and bonds, the relationship of price and interest rates of bond and uncomplicated concepts of diversification (Rooij, Lusardi, \& Alessie, 2007). They 
rely on their savings for investment; savings help them to smooth their consumption and to do productive investment (Karlan, Ratan, \& Zinman, 2014).

The decision of investment is a difficult one with serious opposing selection of risk. Once an illiquid investment is made, the success of such investment is highly dependent on managers (Fried, \& Hisrich, 1994). Financial literacy is essential for planning and decision making. One of the reasons of the peoples' failure of planning is because they are financially less literate and inexperienced. Literacy level of investor influences planning processes and this will lead to increase the wealth of the holder (lusardi \& Mitchell, 2007; Jappelli $\&$ Padula, 2013). One of the factors which influence the effect of investment decision is financial literacy (Rooij, Lusardi, \& Alessie, 2007; Al-Tamimi \& Kalli, 2009; Rooij \& Lusardi, 2010). Financial literacy level of individual is influenced by the level of income and education. Individuals who have high income, holds high educational degrees and those who work in the area of finance and investment are expected to have higher financial literacy level than others (Al-Tamimi \& Kalli, 2009). Financial literacy is typically related to financial education and financial outcome (Huston , 2010) and it can be improved only if individuals are determined to make risky choices that can be corrected by involvement in the decision-making process, and it can also be improved with a providence of better quality of information to decision makers (Altman, 2012).The responses of investor regarding investment decision vary with increase and decrease in the prices of stock (Sturm, 2003). From all above evidences it can be conclude that financial literacy have a positive impact on investment decision making.

\section{Hypothesis 2. Financial Literacy is positively related to Investment Decision Making.}

\section{Mediating role of Risk Perception between Financial Literacy and Investment Decision}

People use different ways in addressing the work related decisions or personal decisions that contains uncertainty and risk. These differences among individuals are frequently described as risk perception or risk attitude. To get desired outcome, investor should have an understanding and knowledge of risk associated with investment. It is necessary that investor understand the risks of investing in securities (Dvorak \& Hanley, 2012). Risk aversion is representative of the utility of money; people are risk averse for higher gain and for lower loss and risk seekers who focused on lower gain and higher loss (Warneryd, 1996). Loss-aversion attitude of investor is associated with a probability of participation in investment. Higher lossaversion lessens the likelihood of direct stockholding by significantly more than the possibility of keeping mutual funds (Dimmock \& Kouwenberg, 2010). Time period plays an important role is risk perception attitude of investor. Investors are seen to be more risk averse in creating portfolio decision on the basis of 1 year data than on the basis of 10 year data (Anderson, \& Settle, 1996).

Bay, Catasu and Johed (2014) explained literacy as the aptitude to read and write; the skill to use language efficiently further they said that the financial literacy is not only the ability to read, write and understand the language of accounting and finance, instead financial literacy need practice because characteristics that formulate the financial literacy is vary with place and time. The psychology of an investor is associated with individual's age and income level, knowledge and way to assume the perception of risk (Walia \& Kiran, 2012). Investors who are financially literate are more risk takers; they invest in risky securities, and those who are not aware with financial products are risk averse and they are less likely to invest in risky securities. The sophisticated level of information provided to investor will encourage him to tolerate more risk (Kaufmann \& Weber, 2013). Perceive investment risk is a predictor of financial literacy (Sachse, Jungermann, \& Belting, 2012). Financial literacy of an investor has positive relationship with risk perception of investor.

Risk plays a dominant role in decision making (Forlani \& Mullins, 2000). Like in other domain the risk perception attitude of investor also play an important role in decisions related to investment. Risk perception has a significant impact on investment decision. Study suggested that the risk perception attitude of investor is affected by the pricing of stocks in stock market (Grable, Lytton, \& O'Neill, 2004). News reveals in stock market regarding the prices of stocks and bonds will affect the investor's investment decision which was reflects the risk perception attitude of individual.

From the above evidences it is concluded that financial literacy has positive impact on risk perception attitude of individual. People who are financially literate are more exposed to the risk; they are risk takers and individuals who are not financially literate are usually risk averse, they hesitate to invest in risky assets. Further study suggested that the decision making process of investor reflect its risk perception attitude and investment decision making is greatly influenced by financial literacy. According to Bönte and Filipiak (2010) investors risk attitude has significant impact on investment decision making which lead to influence the information seeking activities and in turn increase the awareness of individual about financial instruments. 
According to our observation risk perception plays a mediating role between financial literacy and investment decision.

Hypothesis 3. Risk Perception plays a mediating role between Financial Literacy and Investment Decision.

\section{Mediating role of risk perception between emotional intelligence and investment decision}

To get desired outcome, investor should have an understanding and knowledge of risk associated with investment. It is necessary that the investor understands the risks of investing in securities (Dvorak, \& Hanley, 2012). Selection of securities is associated with perception of risk attitude of investor. The degree of risk associated with investment is because of selection (Lintner, 2014).

Risk perception attitude of investor is strongly linked with his personality type. Some individual are risk taker and others are risk averse; both of these attitude depend on the nature of individual. It is assumed that people who are able to manage their emotions are risk takers, as emotional intelligence (EI) involves management of emotions (Arora et al, 2010) and people who have less control over their emotions and feelings are introvert and considered risk averse. Emotional intelligence is arrangement of emotions (Bar-On, Tranel, Denburg, \& Bechara, 2003). Risk perception attitude of individual contain emotional aspect. Risk and uncertainty is subjectively perceived and it involves psychological and emotional factors (Virlics, 2013).

Investor evaluates the risk and returns of all the available investment alternatives and then makes the investment decision accordingly (Andersson \& Gong, 2010). Decision will be more affected by the individual's intolerance of uncertainty or risk (Iyer, McBride, \& Reckers 2012). Investment decision is greatly affected by the behavior of investor regarding risk taken. Risky decision-making is a process of incorporating the desirability of different outcomes (Shiv, Loewenstein, \& Bechara, 2005). So from the above evidences, we could conclude that emotional intelligent individual are more exposed to risk taken behavior and investment decision making is also affected by the risk perception, so risk perception plays an important role between emotional intelligence and investment decision making

Hypothesis 4. Risk Perception plays a Mediating role between Emotional Intelligence and Investment Decision.
FIGURE 1

Theoretical framework

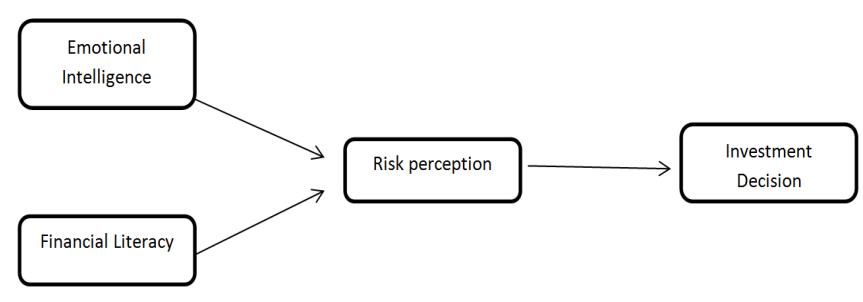

\section{RESEARCH METHODOLOGY}

\section{Sampling}

The sample was consisting of investors who had invested in different stock exchange in Pakistan and abroad. Total of 225 questionnaires were distributed in Islamabad stock exchange and in different banks and in offices. Out of 225 questionnaires 173 were received from which 152 usable; hence the response rate was $67.5 \%$.

The respondents consisted of $82.9 \%$ (126) male and $17.1 \%$ (26) female. The mean age of respondents was between 18-25. Education levels ranged from high school to Ph.D. from which with $0.7 \%$ of the respondents was having a matriculation degree, $3.9 \%$ were intermediate, $27.6 \%$ Bachelors, 50\% Masters, $16.4 \%$ MS and $1.3 \%$ were Ph.D holders. $51 \%$ of investors had experience from 1-5 years in investment, and other $49 \%$ had experience of more than 5 years in investment.

\section{Measurement of Variables}

All item scales of the variables were adopted from prior studies where they had been tested for reliability and validity. A 5 point Likert scale having a range from strongly disagrees to strongly agree was used.

The 14 scale questionnaire to measure the emotional intelligence was adopted from Wong and Law Emotional Intelligence Scale (WLEIS) (Wong \& Law, 2002) having a reliability of 0.776

A 14 items Financial literacy questionnaire was measured using a scale adopted from Ekambaram et al (2003) having a reliability of 0.809

The risk perception attitudes of the investors was measured by 14 items questionnaire using a point biserial correlation adapted from Weber and Milliman (1997) with a reliability of 0.754

Investor behavior was measured using State Street's approach. After excluding an item, reliability reached 0.736 


\section{RESULTS}

TABLE 1

Correlation analysis

\begin{tabular}{lcccccc}
\hline Variable & Mean & SD & $\mathbf{1}$ & $\mathbf{2}$ & $\mathbf{3}$ & $\mathbf{4}$ \\
\hline 1. Emotional Intelligence & 3.5606 & .57718 & 1 & & & \\
2. Financial Literacy & 3.1302 & .65461 & $.282^{* *}$ & 1 & & \\
3. Risk Perception & 3.3036 & .56040 & $.457^{* *}$ & $.604^{* *}$ & 1 & \\
4.Investment Decision & 3.3515 & .55933 & $.452^{* *}$ & $.504^{* *}$ & $.581^{* *}$ & 1 \\
\hline
\end{tabular}

$* * \mathrm{P}<0.001,{ }^{*} \mathrm{p}<0.05$

Correlation analyses show a significant literacy are positively and significantly correlated relationship between the independent variables to risk perception $(.457 * *, .604 * *, * * \mathrm{p}<0.001)$. (emotional intelligence and financial literacy) and Correlation Analysis also shows that investor mediation variable (risk perception). The table behavior is positively and significantly correlated specifies that emotional intelligence and financial to risk perception $(.581 * *, * * p<0.001)$.

TABLE 2

Regression Analysis

\begin{tabular}{|c|c|c|c|c|c|c|}
\hline \multirow[b]{2}{*}{ Predictor } & \multicolumn{3}{|c|}{ Risk Perception } & \multicolumn{3}{|c|}{ Investment Decision } \\
\hline & $\beta$ & $\mathbf{R}^{2}$ & $\Delta \mathbf{R}^{2}$ & $\beta$ & $\mathbf{R}^{2}$ & $\Delta \mathbf{R}^{2}$ \\
\hline \multicolumn{7}{|l|}{ Step 1} \\
\hline Control variable & .006 & & & .031 & & \\
\hline \multicolumn{7}{|l|}{ Step 2} \\
\hline Emotional intelligence & 274 & & & .290 & & \\
\hline Financial literacy & .482 & .476 & .470 & .395 & .402 & .371 \\
\hline \multicolumn{7}{|l|}{ Mediation } \\
\hline \multicolumn{7}{|l|}{ Step 1} \\
\hline Control variable & & & & .031 & & \\
\hline \multicolumn{7}{|l|}{ Step 2} \\
\hline Risk perception & & & & .580 & .367 & .336 \\
\hline
\end{tabular}

$N=152$, Control Variables: Age, Qualification and Gender, ${ }^{* *} p<0.001,{ }^{*} p<0.05$

TABLE 3

Mediation Regression Analysis

Investment decision

\begin{tabular}{lccc}
\multicolumn{1}{r}{ Predictor } & $\boldsymbol{\beta}$ & $\mathbf{R}^{2}$ & $\Delta \mathbf{R}^{2}$ \\
\hline Step 1 & & .031
\end{tabular}

Control Variables

Step 2

Mediation

$.580 \quad .367$

.336

Step 3

Emotional Intelligence $\quad .206$

\begin{tabular}{llll} 
Financial literacy & .246 & .452 & .085 \\
\hline$N=152, \quad$ Control Variables: & Age, & Qualification and
\end{tabular} Gender, ${ }^{* *} p<0.001,{ }^{*} p<0.05$

The regression and mediation regression analysis was used to examine the mediating role of risk perception behavior of investor between emotional intelligence and investment decision making, and also between financial literacy and investment decision making. The results show that after controlling the control variables and mediation, there still exists a significant relationship between emotional intelligence and investment decision ( $\beta=0.206, p=0.002$ ), and subsequently in the case of financial literacy, after controlling control variables and mediation, there still exist a significant relationship between financial literacy and investment decision $(\beta$ $=0.246, \mathrm{p}=0.001)$. This shows that the relationship of dependent and independent variables don't need any mediating variable.

\section{CONCLUSION \& DISCUSSION}

The purpose of our research article was to find the significant impact of investor's emotional intelligence and financial literacy on investment decision making with a mediating role of risk perception behavior of 
investors. For this purpose we developed hypothesis on the basis of previous literature and test those hypothesis by using different measurement tools.

Generalizing our results, two of our hypothesis; $\mathrm{H}_{1}$ and $\mathrm{H}_{2}$ have been accepted and two of our hypothesis; $\mathrm{H}_{3}$ and $\mathrm{H}_{4}$ has been rejected. The direct link between emotional intelligence and investment decision making and the direct link between financial literacy and investment decision making has been accepted. However, when we studied these two relationships under risk perception, the result was totally opposite to our expectations which lead to rejection of our hypothesis.

Studies show a significant relationship between emotional intelligence and investment decision making of an investor. Investors who are emotionally intelligent are good decision makers. Like previous studies, our results also show a significant relationship between investors' emotional intelligence and investment decision making.

Literature also suggested that those investors who have knowledge of financial products and stock market behavior can make decisions by considering the entire factor that could affect their decision as per their awareness. We found the same significant and positive relationship between investors' financial literacy and investment decision making.

However, when we examined the association of emotional intelligence and financial literacy with investment decision making of investor under the risk perception attitude of investor in the same setting, we found an insignificant relationship between them. Risk perception attitude of investor did not play a significant mediated role between the relationship of emotional intelligence and financial literacy with investment decision making. One of the reasons of the rejection of this hypothesis is could be that the risk perception behavior of investor is an inherent characteristic of an individual that does not get affected by the dynamics like emotional intelligence and financial literacy. Individual either has a risk aversion attitude or risk taking attitude, both of these attitudes is engrossed from parents and surroundings and proceeds up to the entire life of an individual. However the aspects emotional intelligence and financial literacy could only increase or decrease the intensity of this behavior, but could not totally change the attitude of investor i.e. from risk aversion behavior to risk taking behavior. If a person has a risk aversion behavior, he would invest in less risky securities, despite of his substantial knowledge about the dynamics of stock markets.

\section{Limitations}

As the study was conducted for the academic purpose, the sample size chosen for the study was quite small. However, considering the significance of this study the sample size should have been much larger.

\section{Future Extension of the Study}

The research focused on financial literacy, emotional intelligence, perceived risk attitudes as factors determining investor's investment decision making. However, the study identified some other areas which need to be explored in further clarifying the investors' decision making.

The zones are suggested for further research, would investors' trust regarding investment in stock market and its impact on investment decision making and the role of gender in this process.

\section{REFERENCES}

Andersson, M., \& Gong, P. 2010. Risk preferences, risk perceptions and timber harvest decisions-An empirical study of nonindustrial private forest owners in northern Sweden. Forest policy and economics, 12(5), 330-339.

Altman, M. 2012. Implications of behavioural economics for financial literacy and public policy. The Journal of Socio-Economics, 41(5), 677-690.

Alon, I., \& Higgins, J. M. 2005. Global leadership success through emotional and cultural intelligences. Business Horizons, 48(6), 501-512.

Ahangar, R. G., \& Rooshan, A. A. 2010. Emotional intelligence as determinant/predictor of work performance among executives. In Financial Theory and Engineering (ICFTE), 2010 International Conference on (pp. 147-150). IEEE.

Al-Tamimi, H. A. H. 2009. Financial literacy and investment decisions of UAE investors. Journal of Risk Finance, The, 10(5), 500-516.

Anderson, B. F., \& Settle, J. W. 1996. The influence of portfolio characteristics and investment period on investment choice. Journal of Economic Psychology, 17(3), 343-358.

Arora, S., Ashrafian, H., Davis, R., Athanasiou, T., Darzi, A., \& Sevdalis, N. 2010. Emotional intelligence in medicine: a systematic review through the context of the ACGME competencies. Medical education, 44(8), 749-764.

Bönte, W., \& Filipiak, U. 2012. Financial literacy, information flows, and caste affiliation: Empirical evidence from India. Journal of Banking \& Finance, 36(12), 3399-3414.

Bay, C., Catasús, B., \& Johed, G. 2012. Situating financial literacy. Critical Perspectives on Accounting.

Bar On, R., Tranel, D., Denburg, N. L., \& Bechara, A. 
(2003). Exploring the neurological substrate of emotional and social intelligence. Brain, 126(8), 1790-1800.

Barling, J., Slater, F., \& Kelloway, E. K. 2000. Transformational leadership and emotional intelligence: an exploratory study. Leadership \& Organization Development Journal, 21(3), 157161.

Disney, R., \& Gathergood, J. 2013. Financial literacy and consumer credit portfolios. Journal of Banking \& Finance, 37(7), 2246-2254.

Duca, J. V., \& Kumar, A. 2014. Financial literacy and mortgage equity withdrawals. Journal of Urban Economics, 80, 62-75.

Dvorak, T., \& Hanley, H. 2010. Financial literacy and the design of retirement plans. The Journal of Socio-Economics, 39(6), 645-652.

Dimmock, S. G., \& Kouwenberg, R. 2010. Lossaversion and household portfolio choice. Journal of Empirical Finance, 17(3), 441-459.

Derksen, J., Kramer, I., \& Katzko, M. 2002. Does a selfreport measure for emotional intelligence assess something different than general intelligence?. Personality and Individual Differences, 32(1), 3748.

Forlani, D., \& Mullins, J. W. 2000. Perceived risks and choices in entrepreneurs' new venture decisions. Journal of Business Venturing, 15(4), 305-322.

Gardner, L., \& Stough, C. 2002. Examining the relationship between leadership and emotional intelligence in senior level managers. Leadership \& Organization Development Journal, 23(2), 6878 .

Grable, J., Lytton, R., \& O'Neill, B. O. 2004. Projection Bias and Financial Risk Tolerance. Journal of Behavioral Finance, 5(3), 142-147.

Goleman, D. P. 1995. Emotional intelligence: Why it can matter more than IQ for character, health and lifelong achievement.

Huston, S. J. 2010. Measuring financial literacy. Journal of Consumer Affairs, 44(2), 296-316.

HjYunus, N., \& Hassan, C. N. 2012, May. The importance of emotional intelligence and soft skills in the workplace. In Innovation Management and Technology Research (ICIMTR), 2012 International Conference on (pp. 12-16). IEEE.

Hess, J. D., \& Bacigalupo, A. C. 2011. Enhancing decisions and decision-making processes through the application of emotional intelligence skills. Management Decision, 49(5), 710-721.

Jappelli, T., \& Padula, M. 2013. Investment in financial literacy and saving decisions. Journal of Banking \& Finance, 37(8), 2779-2792.

Jappelli, T., \& Padula, M. 2013. Investment in financial literacy and saving decisions. Journal of Banking \& Finance, 37(8), 2779-2792.

Karlan, D., Ratan, A., \& Zinman, J. 2013. Savings by and for the Poor: A Research Review and Agenda. Review of Income and Wealth.

Kaufmann, C., \& Weber, M. 2013. Sometimes less is more-The influence of information aggregation on investment decisions. Journal of Economic Behavior \& Organization, 95, 20-33.

Killian, K. D. 2012. Development and Validation of the Emotional Self Awareness Questionnaire: A Measure of Emotional Intelligence. Journal of marital and family therapy, 38(3), 502-514.

Kangyin, L., Yanguo, B., \& Yujie, W. 2011, August. Study on the Relationship between Emotional Intelligence and Employee Performance. In Management and Service Science (MASS), 2011 International Conference on (pp. 1-4). IEEE.

Iyer, G., McBride, D., \& Reckers, P. 2012. The effect of a decision aid on risk aversion in capital investment decisions. Advances in Accounting, 28(1), 64-74.

Leary, M. M., Reilly, M. D., \& Brown, F. W. 2009. A study of personality preferences and emotional intelligence. Leadership \& Organization Development Journal, 30(5), 421-434.

Lusardi, A., \& Mitchell, O. S. 2007. Baby boomer retirement security: The roles of planning, financial literacy, and housing wealth. Journal of monetary Economics, 54(1), 205-224.

Lintner, J. 1965. The valuation of risk assets and the selection of risky investments in stock portfolios and capital budgets. The review of economics and statistics, 13-37.

Lee, T. D., Yun, T. W., \& Haley, E. 2012. The Interplay between Advertising Disclosures and Financial Knowledge in Mutual Fund Investment Decisions. Journal of Consumer Affairs, 46(2), 260-287.

Lusardi, A., \& van Rooij, M. 2010. Financial literacy: Evidence and implications for consumer education. Netspar panel paper, 16.

Matthews, G., Zeidner, M., \& Roberts, R. D. (2012). Emotional intelligence: A promise unfulfilled? Japanese Psychological Research, 54(2), 105127.

Mayer, J. D., \& Salovey, P. 1993. The intelligence of emotional intelligence. Intelligence, 17(4), 433442.

Mayer, J. D., Caruso, D. R., \& Salovey, P. 1999. Emotional intelligence meets traditional standards for an intelligence. Intelligence, 27(4), 267-298.

Mayer, J. D., \& Salovey, P. 1995. Emotional intelligence and the construction and regulation of feelings. Applied and preventive psychology, 4(3), 197-208. Mayer, J. D., \& Geher, G. (1996). Emotional intelligence 
and the identification of emotion. Intelligence, 22(2), 89-113.

Marcolin, S., \& Abraham, A. 2006. Financial literacy research: Current literature and future opportunities.

Petrides, K. V., \& Furnham, A. 2000. On the dimensional structure of emotional intelligence. Personality and individual differences, 29(2), 313-320.

Picard, R. W., Vyzas, E., \& Healey, J. 2001. Toward machine emotional intelligence: Analysis of affective physiological state. Pattern Analysis and Machine Intelligence, IEEE Transactions on, 23(10), 1175-1191.

Sachse, K., Jungermann, H., \& Belting, J. M. 2012. Investment risk-The perspective of individual investors. Journal of Economic Psychology, 33(3), 437-447.

Quinn, J. F., \& Wilemon, D. 2009, August. Emotional intelligence as a facilitator of project leader effectiveness. In Management of Engineering \& Technology, 2009. PICMET 2009. Portland International Conference on (pp. 1267-1275). IEEE.

Riggio, R. E., \& Reichard, R. J. 2008. The emotional and social intelligences of effective leadership: An emotional and social skill approach. Journal of Managerial Psychology, 23(2), 169-185.

Sevdalis, N., Petrides, K. V., \& Harvey, N. 2007. Trait emotional intelligence and decision-related emotions. Personality and Individual Differences, 42(7), 1347-1358.

Schutte, N. S., Malouff, J. M., Hall, L. E., Haggerty, D. J., Cooper, J. T., Golden, C. J., \& Dornheim, L. (1998). Development and validation of a measure of emotional intelligence. ;8 Personality and individual differences, 25(2), 167-177

Saklofske, D. H., Austin, E. J., \& Minski, P. S. 2003. Factor structure and validity of a trait emotional intelligence measure. Personality and Individual Differences, 34(4), 707-721.

Salovey, P., \& Mayer, J. D. 1990. Emotional intelligence. Imagination, cognition and personality, 9(3), 185-211.

Scott Ladd, B., \& Chan, C. C. 2004. Emotional intelligence and participation in decision making: strategies for promoting organizational learning and change. Strategic Change, 13(2), 95-105.
Scott Ladd, B., \& Chan, C. C. 2004. Emotional intelligence and participation in decision making: strategies for promoting organizational learning and change. Strategic Change, 13(2), 95-105.

Shiv, B., Loewenstein, G., \& Bechara, A. 2005. The dark side of emotion in decision-making: When individuals with decreased emotional reactions make more advantageous decisions. Cognitive Brain Research, 23(1), 85-92.

Thorndike, R. L., \& Stein, S. 1937. An evaluation of the attempts to measure social intelligence. Psychological Bulletin, 34(5), 275.

Virlics, A. 2013. Investment Decision Making and Risk. Procedia Economics and Finance, 6, 169-177.

Van Rooij, M., Lusardi, A., \& Alessie, R. 2011. Financial literacy and stock market participation. Journal of Financial Economics, 101(2), 449-472.

Van Rooij, M., Lusardi, A., \& Alessie, R. 2007. Financial literacy and stock market participation (No. w13565). National Bureau of Economic Research.

Wang, C., \& Wang, X. 2010, July. Differences on emotional intelligence in negotiation: A crosscultural investigation. In Advanced Management Science (ICAMS), 2010 IEEE International Conference on (Vol. 3, pp. 404-408). IEEE.

Wang, M., Keller, C., \& Siegrist, M. 2011. The less you know, the more you are afraid of - a survey on risk perceptions of investment products. Journal of Behavioral Finance, 12(1), 9-19.

Walia, N., \& Kiran, R. 2012. Understanding the Risk Anatomy of Experienced Mutual Fund Investors. Journal of Behavioral Finance, 13, 119-125.

Wong, C. S., \& Law, K. S. 2002. The effects of leader and follower emotional intelligence onperformance and attitude: An exploratory study. Leadership Quarterly, 13, 243-274.

Wärneryd, K. E. 1996. Risk attitudes and risky behavior. Journal of Economic Psychology, 17(6), 749-770.

Weber, E. U., \& Milliman, R. A. (1997). Perceived risk attitudes: Relating risk perception to risky choice. Management Science, 43(2), 123-144.

Yao, Y., Wang, R. T., \& Wang, K. 2009. The influence of emotional intelligence on job performance: Moderating effects of leadership. The Institute of Electrical and Electronics Engineers.

Zvaríková, K., \& Majerová, J. 2014. Financial Literacy in the Slovak Republic. Procedia-Social and Behavioral Sciences, 110, 1106-1115. 


\title{
FACTORS AFFECTING CONSUMERS' ATTITUDE TOWARDS MOBILE MARKETING IN PAKISTAN
}

\author{
ZERNIGAH IRSHAD KIANI \\ Mohammad Ali Jinnah University, Islamabad, Pakistan
}

\begin{abstract}
The rapid change in technology and mobile phones has created new channels for marketing. Mobile marketing is an emerging marketing trend that has gained attention, and is becoming a popular direct marketing tool for marketers across the world. The Present research investigates factors affecting consumers' attitude towards mobile marketing and explores the moderating role of permission based mobile marketing. The data was gathered by means of an adapted questionnaire from 123 respondents from the twin cities of Pakistan, Islamabad and Rawalpindi. Correlation and regression analysis were used to find out the relationship between the dependent variable of attitude towards mobile marketing and independent variables of perceived informativeness, entertainment, irritation and source credibility, and a moderating affect of permission-based mobile marketing was analyzed. The study findings indicate that consumers generally have positive attitude towards mobile marketing. Entertainment was found to be the most significant factor affecting consumers' attitude followed by source credibility whereas permission-based mobile marketing did not moderate the relationship between irritation and attitude towards mobile marketing. Some of the managerial implications are that mobile marketing messages should be designed keeping in mind consumers' preferences for the information content, entertainment as well as the source credibility. Timely and relevant information should be provided to generate more favorable attitudes. Moreover, consumers' privacy concerns should be valued by companies practicing mobile marketing so that consumers show their willingness to provide companies with their mobile numbers and demographical data so that companies can send advertising messages with consumers' prior permission.
\end{abstract}

\section{INTRODUCTION}

Mobile marketing has become the latest marketing trend and has gained popularity as a direct marketing tool across the world. Globally, the advertising industry's interest in using mobile phones as a medium for marketing communication is on its rise (Bauer, Barnes, Reichardt, \& Neumann, 2005), and mobile devices are supposed to be influential channels for marketing communication (Nysveen, Pedersen, Thorbjornsen, \& Berthon, 2005). Advertisers are using this tool in their marketing campaigns (Hurwitz, 2009) because of its high penetration rate and low costs associated with it (Leppaniemi \& Karjaluoto, 2008; Komulainen, Mainela, Tahtinen \& Ulkuniemi, 2007), and help create relationships between customers and marketers thus making it a two-way means of communication.

With the advent of mobile marketing the horizons of marketing have also expanded and now marketers can connect with their customers' any place and anytime, thereby making the connectivity easy and efficient (Scharl, Dickinger, \& Murphy, 2005). Many of the successful brands worldwide have integrated this channel for the advertising of their goods and services (Merisavo et al., 2007). Once mobile advertising succeeds in building personal relationships with its customers, it promises increase in sales of different products and services (Leppaniemi \& Karjaluoto, 2005), and businesses consider it as a valuable tool for creating brand awareness and image (Okazaki, 2005).

Globally, the adoption of mobile phones has been tremendous (Stump, Gong, \& Li, 2008) and mobile phones have become an essential part of our day to day lives (Bosnjak, Metzger, \& Graf, 2010). According to the statistics, Pakistan is the seventh largest country in terms of mobile phone users with total number of subscriptions crossing the figure of 108 million in the year 2011, and more than $65 \%$ of the population is having a mobile phone (Telecom Indicators, 2011). This channel provides real opportunities for businesses to acquire new customers and to communicate with the current ones (Blanco, Blasco \& Azorin, 2010) 
thereby establishing its importance as a marketing communication tool.

Research conducted in various parts of the world usually show that consumers hold negative attitude towards mobile marketing (Drossos, Giaglis, Lekakos, Kokkinaki, \& Stavraki, 2007; Tsang, Ho, \& Liang, 2004; Rettie \& Brum, 2001), and a weak acceptance of mobile phone marketing has been observed (Roach, 2009). Although mobile phones have been increasingly used for marketing communication, a lot is to be explored about this channel and consumers' perceptions towards this medium in order to remove possible negative effects. Little experience is possessed by the businesses for the usage of mobile marketing tool (Dickinger, Haghirian, Murphy, \& Scharl, 2004), and consumers have not yet realized its importance as an advertising channel (Phau \& Teah, 2009).

Similarly more features are to be identified that create positive and negative attitude towards mobile advertising (Saadeghvaziri \& Hosseini, 2011). Therefore, this study tends to investigate consumers' attitude towards mobile marketing in Pakistan and the underlying factors that can enhance consumers' perceptions towards this medium of marketing. In a country like Pakistan, where the usage of mobile phones is sky high and observed to be increasing tremendously, marketers should pay emphasis as to what factors contribute towards the effectiveness of mobile marketing campaigns and its acceptance by consumers, because in the present time, the potential of this tool for marketing communication is observed to be underutilized in Pakistan. Many of the past studies have focused only on young consumers' perceptions of mobile marketing while ignoring the other half. As the use of mobile phones is same across all age groups, therefore, this study tends to explore consumers' attitude across all age groups and their relevant perceptions regarding this channel of marketing communication, specifically, in terms of factors such as informativeness, entertainment, source credibility and irritation that are linked with mobile marketing messages.

\section{REVIEW OF LITERATURE}

\section{Mobile Marketing}

Mobile marketing makes use of mobile devices such as mobile phones and personal digital assistants for the transmission of advertising messages (Lee, Hsieh, \& Huang, 2011), where SMS messages are sent by marketers to their customers and general public (Boadi, Boateng, Hinson, \& Opoku, 2007). With the emergence of new technologies, mobile phones have become attractive for consumers and has gained huge acceptance (Pajnik \& Tusek, 2002) and throughout the developed world, the use of mobile phones has been tremendous among teenagers and young adults (Axelsson, 2010). Therefore, advertisers have uncovered the importance of mobile marketing medium for the initiation of communication between customers and company, thereby resulting into superior customer relationship management (Sinisalo, Salo, Leppaniemi, \& Karjaluoto, 2005). By making use of mobile technology, companies have reached their customers in an efficient manner which had not been possible with the use of traditional media as mobile marketing is an innovative and effective way of communicating with customers (Sinisalo, Salo, Karjaluoto, \& Leppaniemi, 2006).

Mobile phone is a very personal device and consumers have it with them all the time thereby making its use anywhere and anytime. Hence it is easy to transmit marketing information by means of messaging (Okazaki, 2005), and with the use of SMS/ MMS companies can build emotional relationship with their customers, and can become a part of their daily lives, thereby strengthening their loyalty to the brand (Nsyveen, Pedersen, Thorbjornsen, \& Berthon, 2005).

Short messaging service (SMS) is one of the most successful mobile services in present times and is largely used for the purpose of communication and interaction (Nysveen et al., 2005). Similarly, SMS channel provides companies with a communication platform which is an excellent mean of transmitting information about new products and services, thereby allowing the company to grow and expand (Kleijnen, Lievens, Ruyter, \& Wetzels, 2009). According to Radder, Pietersen, Wang, and Han (2010), mobile marketing will remain a leading direct marketing tool because of lower costs associated with it and because of the novelty of the medium, therefore, to increase its acceptance, incentives should be provided to the early adopters as consumers only accept advertisements which benefit them and are of their interest.

\section{Factors Affecting Consumers' Attitude towards Mobile Marketing}

\section{Informativeness}

Informativeness refers to the effectiveness of advertising programs in providing consumers with necessary information that helps them in decision making (Lee-Wingate \& Xie, 2010). Advertising is a primary source of information for consumers (Wang, 2007), and as perceived utility and informativeness are the main determinants of mobile marketing, therefore, latest information should be provided to consumers in 
order to tie them more closely to the firm (Merisavo et al., 2007). Similarly, the information service quality of advertisements should be improved so as to build consumers' loyalty towards mobile information services (Kondo, Hirata, \& Akter, 2010).

The diffusion of mobile phones and its usage as a marketing medium is growing rapidly, therefore, it is important that the advertising messages should be kept simple and relevant, containing content that consumers desire for in order to achieve the desired outcome (Jenkins, 2006). According to Coursaris, Sung, and Swierenga (2010), while designing mobile advertisements, both utilitarian and hedonic values should be incorporated into the advertising messages. Utilitarian value means that advertisements should make consumers learn something new about the advertised brand or product and hedonic value in terms of mobile ads being humorous so as to gain consumers' attention. Bamoriya and Singh (2011) observed that consumers who are information seekers tend to have more favorable attitude towards mobile advertisments as compared to those who are not, therefore, informative and entertaining advertisements should be designed to increase consumers' acceptance, as advertising informativeness generates positive consumers' attitude (Saadeghvaziri \& Seyedjavadain, 2011). Therefore, it is suggested that:

\section{Hypothesis 1. The perceived informativeness of mobile marketing messages positively affects consumers' attitude towards mobile marketing.}

\section{Entertainment}

One of an essential factors for mobile advertising is entertainment. So, short and humorous messages should be designed in order to catch consumers' attention instantaneously (Haghirian, Madlberger, \& Tanuskova, 2005). Entertainment enhances the advertising value and generates favorable attitudes as it is observed to have a strong positive effect on the value of advertisement (Xu, Oh, \& Teo, 2009). Consumers consider advertising messages more valuable if they are perceived as entertaining and fun containing and hence place high importance on this aspect of advertising ( $\mathrm{Oh}$ $\& \mathrm{Xu}, 2003)$.

Al-alak and Alnawas (2010) observed that consumers who perceived SMS advertising messages entertaining showed more willingness to participate in mobile marketing, and a positive association was observed between entertainment and consumers' purchase intention. Therefore, humor appeal should be made an integral part of advertisements in order to make them as entertaining as possible (Bamoriya \& Singh, 2011) as it is the most significant factor affecting consumers' attitude towards mobile advertising (Tsang et al., 2004). Hence, it is hypothesized that:

\section{Hypothesis 2. The higher the entertainment factor of mobile marketing messages, more positive attitude consumers have towards mobile marketing.}

\section{Source Credibility}

Source credibility refers to the skills and ability of the communicator conveying the messages and the extent to which the communicator is trusted by the recipient of that communication (Buda \& Zhang, 2000). Similarly, it refers to the expertness and knowledge of the message provider and the message provider's reliability, honesty and trustworthiness for building and increasing consumers' trust (Wu \& Wang, 2011). According to Muzaffar and Kamran (2011) credibility refers to the trustworthiness and efficiency of the source, hence if the source is perceived as credible by consumers, they will be having a positive response towards the advertisement. Therefore, source credibility is observed to have a significant impact on attitude towards the ad and the purchase intention (Clow, Fames, Kranenburg, \& Berry, 2006).

Mobile media advertisements are considered to be more credible as compared to internet advertisements (Jordaan, Ehlers, \& Grove, 2011); hence, by focusing upon strong and positive media presence through advertising, marketers can gain consumers' trust as it is the main factor affecting consumers' participation in mobile marketing (Jayawardhena, Kuckertz, Karjaluoto, \& Kautonen, 2009). Consumers allow advertisers to use their personal information, and appear to trust and accept mobile advertisements only if the company is well-known to them (Kautonen, Karjaluoto, Jayawardhena, \& Kuckertz, 2007). Therefore, it is hypothesized that:

\section{Hypothesis 3. Higher the perceived credibility of mobile marketing messages, more positive attitude consumers have towards mobile marketing.}

\section{Irritation}

SMS channel provides marketers with immense opportunities of transmitting marketing information to the targeted customers, but at the same time makes a company vulnerable to many threats one of which is causing irritation and turning away of potential 
customers (Westell \& Wessing, 2003). Likewise, as mobile phones offer personalization and greater possibility of reaching customers, marketers have been excited for the use of this medium but it has been observed that young consumers relate this medium with irritation, intrusion and mistrust (Grant \& O'Donohoe, 2007).

The perceived irritation of mobile marketing messages negatively influences advertising value $(\mathrm{Oh}$ $\& \mathrm{Xu}, 2003)$, and it has been observed that unsolicited ads create annoyance and consumers are less likely to purchase products on the basis of advertisements that are sent on their mobile phones (McCasland, 2005). Similarly, a greater frequency of exposure to advertisement messages can result into negative attitude towards ads (Saadeghvaziri \& Seyedjavadain, 2011). According to Wang, Oh, and Wang (2009), perceived ad intrusiveness in mobile advertising is observed to be causing irritation and ad avoidance, and it can be reduced by providing relevant and informative content to consumers. Similarly, advertisements are perceived as less intrusive and do not cause irritation if they are promoting products of consumers' interest (Wehmeyer, 2007). Hence it is suggested that:

\section{Hypothesis 4. The perceived irritation of mobile marketing messages negatively influences consumers' attitude towards mobile marketing.}

\section{Permission-based Mobile Marketing}

Permission based mobile marketing is defined as a marketing strategy where SMS advertisements are sent only to the consumers who have granted permission and have shown interest in receiving promotional information on their mobile phones (Waldt, Rebello, \& Brown, 2009). Permission-based mobile marketing will become a vital direct marketing tool in near future as it allows targeting of potential customers on the basis of their present location and disclosed interests, thereby increasing the response rate (Reyck \& Degraeve, 2003).

One of the most common mistakes in conducting $\mathrm{m}$-marketing campaigns is sending marketing messages to consumers without their permission (Salo, Sinisalo, \& Karjaluoto, 2008) because it has been observed that permission based mobile advertising creates positive attitude whereas sending advertising messages without permission generates negative attitude (Tsang et al., 2004). Therefore, permission-based mobile marketing should be adopted in order to reduce customers' irritation because if the messages are sent with customers' consent, there are more chances that the messages would be read and absorbed (Haghirian, Madlberger \& Inoue, 2008). Similarly consumers are more willing to participate in m-marketing activities if they have granted permission to the advertisers. So, in order to make mobile marketing an effective tool, consumers' prior permission should be obtained (Standing, Benson, \& Karjaluoto, 2005).

By providing relevant, requested and interactive content to consumers, mobile marketing can become a successful and lucrative industry but it is important to respect consumers' privacy (Kavassalis et al., 2003) because even if the advertisements are informative and relevant, consumers do not like to be bombarded with advertising messages or receiving advertisements at inappropriate time and place (Zhang, Guerrero, Wheatley, \& Lee, 2010). Moreover, company's reputation may also get damaged by means of sending SMS advertisements without prior permission (Muzaffar \& Kamran, 2011). Therefore, in order to turn consumers' attitude positive towards mobile advertising, messages should be sent with their prior permission (Mir, 2011). Therefore, it is stated that:

\section{Hypothesis 5. Permission-based mobile marketing moderates the relationship between irritation and consumers' attitude towards mobile marketing.}

\section{Attitude towards Mobile Marketing}

Consumers' attitude towards advertisements affects their attitude towards the brand (Tan \& Chia, 2007). According to Wang (2007), effective mobile marketing requires a deep understanding of customers' preferences, i.e., what the customers are really looking for in mobile marketing and how they perceive mobile promotions and offerings. Despite the potential of mobile marketing, reluctance has been observed by customers for its adoption and certain challenges are being faced by mobile advertisers (Wilken \& Sinclair, 2009). Consumers hold negative attitudes towards SMS advertisements especially when they are unsolicited, therefore, in order to avoid negative attitude, marketers should not ask for information which the consumers are not willing to provide (Bamba \& Barnes, 2007). Similarly in another study conducted on college students, it was observed that in general, consumers' attitude towards mobile promotions was not positive (Wang \& Acar, 2006) and they perceive SMS as a less effective channel for marketing communication as compared to traditional media. However, as the use of SMS is highest among younger population, young consumers' are more likely to accept offers sent via SMS (Danaher \& Rossiter, 
2011).

Keshtgary and Khajehpour (2011) observed that Iranian consumers do not hold negative attitudes towards mobile marketing but taking prior permission may generate more favorable attitude. Moreover, traditional mobile advertising messages that comprise of impersonalized marketing messages are usually treated as junk messages (Chen, Hsieh, Cheng, \& Lin, 2009). So, in order to increase the acceptance of mobile marketing and to enhance its usage among customers, personalized messages should be delivered as they offer additional value for the customers (Gurau \& Ranchhod, 2009).

The value of location based mobile advertising significantly drops if it is pushed at consumers therefore, care should be taken regarding consumers' privacy concerns and timely and relevant information should be provided (Unni \& Harmon, 2007). Moreover, the degree of risk acceptance and consumers' personal attachment to their mobile phones also determine the acceptance of mobile marketing whereby providing incentives can increase consumers' acceptance of advertising messages (Gao, Sultan \& Rohm, 2010). Similarly consumers' attitude towards mobile marketing is also predicted on the basis of its perceived usefulness (Hosseini, Ghazizadeh, Noroozi, Goharpad, \& Mobarekeh, 2011).

It has been advised that marketers should formulate specific marketing plans in order to improve customers' attitude and their acceptance of m-commerce (Pavlou $\&$ Lie, 2006). Managers believe that by means of using appropriate marketing techniques, the acceptance of mobile marketing can be increased among consumers in a short time span and as younger consumers are early adopters of mobile advertising therefore, for marketers, the younger segment of the society is an attractive one (Okazaki \& Taylor, 2008).

On the basis of the reviewed literature following theoretical model has been developed that shows the links between the independent variables and the dependent variable.

FIGURE 1 Theoretical Model

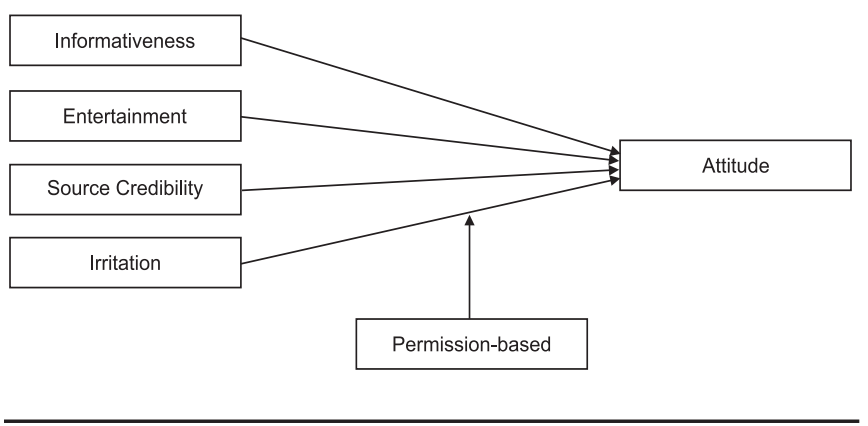

\section{METHODOLOGY}

\section{Sample Size}

Convenience sampling technique has been used for data collection and the data was collected from twin cities of Pakistan, Islamabad and Rawalpindi, by means of personal delivery of questionnaire. The individuals targeted for the collection of data for this research were users of mobile phones and consisted of undergraduate and graduate students of various universities and general consumers who make use of mobile phones. A total of 150 questionnaires were distributed however, only 126 of them were returned so the response rate remained only 82 percent. The respondents included 85 males and 38 females. 70.7 percent of them were between 18 to 30 years of age with the mean respondent age $M=27.63$, whereas 45.5 percent of the respondents were students, which indicates that the respondents' were primarily young and well educated.

\section{Instrumentation}

The instrument used for data collection was a structured, closed ended questionnaire adapted from the study of Tsang et al. (2004) and Kautonen et al. (2007) that studied five dimensions of mobile marketing messages i.e. informativeness, entertainment, source credibility, irritation and permission-based. The questionnaire consisted of two major parts. The first part collected the respondents' demographic data, such as age, gender, education and occupation. The second part asked about the respondents' general attitude towards mobile marketing as measured by five major attributes: informativeness, entertainment, irritation, source credibility and permission based marketing. The questionnaire consisted of 12 items in aggregate. Attitude consisted of one item, informativeness consisted of two items, entertainment consisted of two items, irritation consisted of two items, source credibility consisted of two items and permission-based consisted of three items. Two scales have been used by this research for gathering data from respondents. A five point Likert scale with options ranging from $5=$ strongly agree, $4=$ agree, $3=$ neutral, $2=$ disagree to $1=$ strongly disagree, was used to measure respondents' responses towards the dimensions of mobile marketing whereas nominal scale was used for the collection of the demographical data of respondents.

Cronbach alpha values for individual variables of informativeness was (.762), entertainment (.901), irritation (.796), source credibility (.606) and permission based (.668). The value for the entire questionnaire was .737 . As the value of Cronbach 
alpha for most of the variables and the entire questionnaire was above 0.70 , hence, it ensures the reliability of the collected data and its suitability for further analysis.

\section{RESULTS}

For the purpose of data analysis, statistical package for social sciences (SPSS) version 14 was used. Statistical tests were applied to check the reliability of the data and correlation analysis and regression analysis were conducted in order to see the impact of independent variables over the dependent variable and the effect of moderation.

The correlation analysis, as shown in Table 1 below, depicts that all variables are significantly related to the attitude towards mobile marketing. Informativeness, entertainment and source credibility are positively correlated with the attitude towards mobile marketing whereas irritation is found to be negatively correlated. These results are in accordance with the findings of previous researches.

TABLE 1

\begin{tabular}{lccccc}
\hline & Attitude & Informativeness & Entertainment & Irritation & Source Credibility \\
\hline Attitude & 1 & & & & \\
Informativeness & $.538^{* *}$ & 1 & & & \\
Entertainment & $.689 * *$ & $.608^{* *}$ & 1 & & \\
Irritation & $-.372 * *$ & $-.284^{* *}$ & $-.390 * *$ & 1 & 1 \\
Source & $.641 * *$ & $.458^{* *}$ & $.495^{* *}$ & $-.297 * *$ & 1 \\
Credibility & & & &
\end{tabular}

Entertainment has got the highest correlation value of (.689). Hence a strong positive significant association is observed between entertainment and attitude towards mobile marketing which shows that the entertainment element of mobile advertising greatly affects consumers' attitude towards mobile marketing. Pleasing and entertaining advertisements catch consumers' interest and attention thereby increasing the impact of advertised product or service.

Source credibility turns out to be the second most influential factor affecting consumers' attitude towards mobile marketing. A high significant correlation value of (.641) indicates that consumers only accept and trust the information coming from a trustworthy source. Therefore, source credibility plays an important role in generating positive consumers' attitude towards mobile marketing. Higher the credibility of mobile advertisements, more positive attitude consumers would have towards them.

A significant correlation value of (.538) is observed between informativeness and attitude towards mobile marketing, which shows that both the variables have a strong positive association with each other. Informativeness plays an important role in generating positive consumers' attitude. Therefore, up to date, timely and accurate information should be provided and the messages should be made as valuable as possible so that they may benefit consumers'.

Other constructs are positively associated with consumers' attitude towards mobile marketing but correlation value of (-.372) indicates that irritation is negatively associated with consumers' attitude towards mobile marketing. Though the relationship is not very strong but a significant value of correlation depicts that consumers do get irritated by mobile advertisements, as they are observed to be intrusive in nature and therefore result in negative consumers' attitude. Repeatedly sending same advertisements, containing same content frustrates the consumers and generates negative attitudes.

Multiple regression analysis was conducted to see the combined effect of all independent variables over the dependent variable of attitude towards mobile marketing (See Table 2). The R-square value of (.615) indicates that the independent variables namely informativeness, entertainment, irritation and source credibility cause $61.5 \%$ variation in the dependent variable of attitude towards mobile marketing, whereas $38.5 \%$ of the variation is explained by other variables that are not studied in this model. A significance value of .000 shows the fitness of the model.

Table 2 shows the t-values and significance values of the independent variables. The first variable, i.e. informativeness has a significance value of (.205) and a corresponding t-value of (1.274). This shows a nonsignificant relationship between informativeness and consumers' attitude towards mobile marketing which means that informativeness does not have any impact on attitude towards mobile marketing. These results are in accordance with the findings of Blanco et al. (2010) and Muzaffar and Kamran (2011).

The second variable of entertainment has a 
significance value of (.000) and a t-value of (5.606) which is above the acceptable value of 1.96 . Hence the results show that entertainment significantly impacts consumers' attitude towards mobile marketing. Likewise, a significance value of (.000) and t-value (5.286) shows that source credibility also significantly impacts consumers' attitude towards mobile marketing.

The last variable i.e. irritation shows a significance value of (.286) and a t-value of (-1.071). These insignificant values depict that irritation does not impact consumers' attitude towards mobile marketing.

TABLE 2

Regression Statistics

\begin{tabular}{lccc}
\hline \multicolumn{1}{c}{ Variable } & Beta & t-value & p-value \\
\hline Informativeness & .094 & 1.274 & .205 \\
Entertainment & .438 & 5.606 & .000 \\
Irritation & -.067 & -1.071 & .286 \\
Source Credibility & .361 & 5.286 & .000 \\
\hline R-square & .615 & & \\
Adjusted R-square & .602 & & \\
\hline
\end{tabular}

In order to see whether permission-based mobile marketing moderates the relationship between independent variable of irritation and dependent variable of attitude towards mobile marketing, a moderated regression analysis was carried on. Table 3 shows the results of moderated regression analysis.

TABLE 3

\section{Regression Statistics}

\begin{tabular}{cccc}
\hline Variable & Beta & t-value & p-value \\
\hline Interaction term & .285 & 1.151 & .252 \\
\hline
\end{tabular}

The table above shows a significance value of .252 and a t-value of 1.151 . As the t-value is below the acceptable value of 1.96 so, these insignificant results show that permission-based mobile marketing does not moderate the relationship between irritation and attitude towards mobile marketing.

\section{DISCUSSION}

On the basis of the above analysis, $\mathrm{H}_{1}$ is rejected and hence it is concluded that the perceived informativeness of mobile marketing messages does not result into positive attitude towards mobile marketing. The study findings are contradictory with the findings of researches conducted in other parts of the world. The main reason for such results is that in Pakistan the mobile advertisements are not designed by keeping in view the interests of the recipients. No attention is paid to the individual interests. So, same kind of messages are designed for everyone including youth segment as well as for the middle age and older group of people which reduces the effectiveness of mobile advertising messages, and hence does not create any value for the recipients. Moreover, consumers believe that mobile advertisements do not provide timely information or the information that is required by them, which further worsens their attitude.

Entertainment significantly and positively impacts attitude towards mobile marketing. Therefore, $\mathrm{H}_{2}$ is accepted. The findings of this study are in accordance with the findings of (Tsang et al., 2004: Haghirian et al., 2005). Pleasing and entertaining advertisements should be sent in order to attract consumers' attention towards the advertised product or service. The incorporation of games and other fun elements in advertisements create value for the recipients and increase the acceptance of mobile marketing, especially when the target segment of a mobile marketing campaign consists of younger population, entertainment should be made an essential part of advertising messages to increase the response rate from their campaign as young consumers' are more receptive to entertaining content.

On the basis of the study findings, $\mathrm{H}_{3}$ is also accepted. The results depict a positive relationship between source credibility and consumers attitude towards mobile marketing. So, it can be concluded that higher perceived source credibility results into more favorable attitude towards mobile marketing. These findings are congruent with the studies of (Muzaffar \& Kamran, 2011; Tsang et al., 2004; Haghirian et al., 2005) who came up with the same results. The credibility of the source providing information is very important as consumers only accept and trust information coming for a trustworthy source. Advertisers should build higher source credibility in order to increase the acceptance of their advertisements and to build a positive image of their company or brand in consumers' mind as it strengthens the link between company and its consumers. Furthermore, if consumers perceive information to be truthful and coming from a trustworthy source, they may share it with their family and friends which eventually enlarges and broadens the influence of mobile marketing campaign by the incorporation of viral effects.

Irritation has no significant impact on consumers attitude towards mobile marketing, therefore, $\mathrm{H}_{4}$ is rejected as the results show that perceived irritation of mobile marketing messages does not result into negative attitude. These findings are also in contradiction with many of the western studies which came up with the results that irritation results into negative consumers' attitude. Such difference in the study findings can be 
supported on the basis of the cultural differences. The tolerance level among Pakistanis consumers is observed to be quite high, hence they do not get much bothered by such advertising messages. Likewise, consumers show reluctance towards complaining against such activities of advertisers which further encourages advertisers to continue practicing mobile marketing without taking prior permission. Moreover, as the sample studied for the purpose of this research mostly consisted of young population and the interaction of youth with technological devices, like mobile phones is observed to be quite different and its usage is relatively higher, so they do not get irritated by unwanted SMS advertisements (Muzaffar and Kamran, 2011).

The insignificant results for the moderation affect of permission-based mobile marketing between irritation and consumers' attitude towards mobile marketing leads to the rejection of $\mathrm{H}_{5}$. Although many of the previous researches such as Tsang et al. (2004), Dickinger et al. (2004) and Bamba and Barnes (2007) stated that sending mobile advertisements without consumers consent results into irritation and resentment among message recipients, and acquiring prior permission leads to favorable attitude. The present study findings negate them.

Consumers are not willing to grant permission to advertisers so that they may indulge in the process of permission-based mobile marketing and hence for this reason advertisers continue sending unsolicited mobile advertising messages to consumers without their consent. A major reason for not granting permission is that in our culture, consumers resist sharing their personal information like demographical profile or mobile numbers with companies as it can be used for illegal purposes as a country like Pakistan is vulnerable to terrorist activities and people do not consider it safe to impart their personal information to any company. Hence, advertisers unethically track consumers' data without their permission and use it for mobile marketing purposes.

\section{Implication for Marketers}

Marketers can make use of the study findings to devise mobile marketing campaigns that build positive consumers' attitudes and reduce negative effects. Similarly, the findings may also help advertisers emphasize on dimensions of mobile marketing messages that have not been paid much attention lately, but are likely of receiving recipients' attention as this medium has got the potential of creating value for companies by means of reducing costs. Likewise, by carefully designing advertising messages, advertisers can increase the influence of their campaigns and can generate a response rate much higher as compared to the traditional mediums used for advertising products and services. Moreover, for making consumers a part of mobile marketing campaigns, incentives should be provided to consumers so that they may take part in promoting the campaign effects by sharing it with their family and friends, as it will further increase the source credibility.

Companies should indulge themselves in activities that build positive image of the company in consumers' minds. They should enforce that they have concern for their consumers' privacy rights and hence, take measure for the protection of consumers' rights. By doing this they may gain their consumers trust and eventually consumers would grant permission to the companies willing to practice permission-based mobile marketing.

\section{Limitations}

Some of the limitations identified during the course of this research are that due to the shortage of time the data was collected from a limited number of people. A larger sample size could have generated even better results. Likewise, the data was collected only from the twin cities, Islamabad and Rawalpindi, which limits the generalizability of results across Pakistan. Future studies can be conducted by gathering data from various cities across Pakistan and by taking a larger sample size. This would assist in confirming the findings of this study and would also help to explore the topic in more detail.

\section{CONCLUSION}

For the promotion of mobile marketing tool and its acceptance among consumers it is important for marketers to firstly understand consumers' attitude towards this communication medium because only when advertisers have thoroughly looked into consumers' attitudes and perceptions, they would be able to formulate effective mobile marketing campaigns for the promotion of their products and services. Mobile marketing messages should be providing relevant and timely information to the message recipients in order to create value for them as message relevance is an important element for the success of this marketing tool along with the other factors.

\section{REFERENCES}

Al-alak, B.A.M. \& Alnawas, I.A.M. 2010. Mobile Marketing: Examining the Impact of Trust, Privacy Concern and Consumers' Attitudes on Intention to Purchase. International Journal of Business and Management, 5(3), 28-41.

Axelsson, A. 2010. Perpetual and Personal: Swedish 
Young Adults and Their Use of Mobile Phones.

New Media Society, 12(1), 35-54.

Bauer, H.H., Barnes, S.J., Reichardt, T. \& Neumann, M.M. 2005. Driving Consumers Acceptance of Mobile Marketing: A Theoretical Framework and Empirical Study. Journal of Electronic Commerce Research, 6(2), 181-192.

Bamoriya, H. \& Singh, R. 2011. Attitude towards Advertising and Information Seeking Behavior - A Structural Equation Modeling Approach. European Journal of Business and Management, 3(3), 4554.

Bamba, F. \& Barnes, S.J. 2007. SMS Advertising, Permission and the Consumer: A Study. Business Process Management Journal, 13(6), 815-829.

Bamoriya, H. \& Singh, R. 2011. Information Seeking and Attitude towards Advertising - A Cross-sectional Empirical Study. BIZ and BYTES- A Quarterly Published Journal of Business and Information Management, 3, 1-21.

Blanco, C. F., Blasco, M.G. \& Azorin, I.I. 2010. Entertainment and Informativeness as Precursory Factors of Successful MobileAdvertising Messages. Communications of the IBIMA, 2010(1020), article ID 130147, 1-11.

Boadi, R.A., Boateng, R., Hinson, R. \& Opoku, R.A. 2007. Preliminary Insights into M- C o $\mathrm{m} \mathrm{m}$ e r c e Adoption in Ghana. Information Development, 23(4), 253-265.

Bosnjak, M., Metzger, G. \& Graf, L. 2010. Understanding the Willingness to Participate in Mobile Surveys: Exploring the Role of Utilitarian, Affective, Hedonic, Social, Self-Expressive, and TrustRelated Factors. Social Science Computer Review, 28(3), 350-370.

Buda, R. \& Zhang, Y. 2000. Consumer Product Evaluation: The Interactive Effect of Message Framing, Presentation Order, and Source Credibility. Journal of Product and Brand Management, 9(4), 229-242.

Chen, P., Hsieh, H., Cheng, J.Z. \& Lin, Y. 2009. Broadband Mobile Advertisement: What are the Right Ingredient and Attributes for Mobile Subscribers. Proceedings of PICMET.

Clow, K.E., Fames, K.E., Kranenburg, K.E. \& Berry, C.T. 2006. The Relationship of The Visual Element Of An Advertisement To Service Quality Expectations And Source Credibility. Journal of Services Marketing, 20(6), 404-411.

Coursaris, C.K., Sung, J. \& Swierenga, S.J. 2010. Effects of Message Characteristics, Age, and Gender on Perceptions of Mobile Advertising - An Empirical Investigation among College Students. Ninth International Conference on Mobile Business/
Ninth Global Mobility Roundtable.

Danaher, P.J. \& Rossiter, J.R. 2011. Comparing Perceptions of Marketing Communication Channels. European Journal of Marketing, 45(1/2), 6-42.

Dickinger, A., Haghirian, P., Murphy, J. \& Scharl, A. 2004. An Investigation and Conceptual Model of SMS Marketing. Proceedings of the 37th Hawaii International Conference on System Sciences.

Drossos, D., Giaglis, G.M., Lekakos, G., Kokkinaki, F. \& Stavraki, M.G. 2007. Determinants of Effective SMS Advertising: An Experimental Study. Journal of Interactive Advertising, 7(2), 16-27.

Gao, T., Sultan, F. \& Rohm, A.F. 2010. Factors Influencing Chinese Youth Consumers' Acceptance of Mobile Marketing. Journal of Consumer Marketing, 27(7), 574-583.

Gurau, C. \& Ranchhod, A. 2009. Consumer Privacy Issues in Mobile Commerce: A Comparative Study of British, French and Romanian Consumers. Journal of Consumer Marketing, 26(7), 496-507.

Grant, I. \& O’Donohoe, S. 2007. Why Young Consumers Are Not Open To Mobile Marketing Communications. International Journal of Advertising, 26 (2), 223-246.

Haghirian, P., Maldlberger, M. \& Tanuskova, A. 2005. Increasing Advertising Value of Mobile MarketingAn Empirical Study of Antecedents. Proceedings of the 38th Hawaii International Conference on System Sciences.

Haghirian, P., Madlberger, M. \& Inoue, A. 2008. Mobile Advertising in Different Stages of Development: A Cross-Country Comparison of Consumer Attitudes. Proceedings of the 41st Hawaii International Conference on System Sciences.

Hurwitz, J.B. 2009. The Effect of Mobile Advertising Presentation Parameters on Brand Memory. Proceedings of the Human Factors and Ergonomics Society Annual Meeting.

Hosseini, M.H., Ghazizadeh, M., Noroozi, A., Goharpad, M. \& Mobarekeh, A.H.N. 2011. Marketing Without Wires: Survey of Factors Affecting Mobile Advertising Effectiveness in Iran. 2010 International Conference on Business and Economic Research.

Jayawardhena, C., Kuckertz, A., Karjaluoto, H. \& Kautonen, T. 2009. Antecedents to permission based mobile marketing: an initial examination. European Journal of Marketing, 43(3/4), 473-499. Jenkins, F. 2006. Mobile Marketing. Young Consumers, Quarter 1, 60-63.

Jordaan, Y. Ehlers, L. \& Grove, J.M. 2011. Advertising Credibility across Media Channels: Perceptions of Generation Y Consumers. Communicare, 30(1), 1-20. 
Kavassalis, P., Spyropoulou, N., Drossos, D., Mitrokostas, E., Gikas, G. \& Hatzistamatiou, A. (2003). Mobile Permission Marketing: Framing the Market Inquiry. International Journal of Electronic Commerce, 8(1), 55-79.

Kautonen, T., Karjaluoto, H., Jayawardhena, C. \& Kuckertz, A. 2007. Permission-Based Mobile Marketing and Sources of Trust in Selected European Markets. Journal of Systems and Information Technology, 9(2), 104-123.

Keshtgary, M. \& Khajehpour, S. 2011. Exploring and Analysis of Factors Affecting MobileAdvertising Adoption - An Empirical Investigation among Iranian Users. Canadian Journal on Computing in Mathematics, Natural Sciences, Engineering and Medicine, 2(6), 144-151.

Kleijnen, M., Lievens, A., Ruyter, K.D. \& Wetzels, M. 2009. Knowledge Creation Through Mobile Social Networks and Its Impact on Intentions to Use Innovative Mobile Services. Journal of Service Research, 12(1), 15-35.

Komulainen, H., Mainela, T., Tahtinen, J. \& Ulkuniemi, P. 2007. Retailers' Different Value Perceptions of Mobile Advertising Service. International Journal of Service Industry Management, 18(4), 368-393.

Kondo, F.N., Hirata, J. \& Akter, S. 2010. The Impact of Mobile Amusement Information on Use Behavior, Satisfaction, and Loyalty. Ninth International Conference on Mobile Business/ Ninth Global Mobility Roundtable.

Lee, C., Hsieh, M. \& Huang, H. 2011. The Influence of Mobile Self-Efficacy on Attitude towards Mobile Advertising. Advances in Information Sciences and Service Sciences, 3(3), 100-108.

Lee-Wingate, S.N. \& Xie, Y. 2010. Consumer Perceptions of Product-Claim versus Help-Seeking Direct-toConsumer Advertising. International Journal of Pharmaceutical and Healthcare Marketing, 4(3), 232-246.

Leppaniemi, M. \& Karjaluoto, H. 2005. Factors Influencing Consumers' Willingness to Accept Mobile Advertising: A Conceptual Model. Int. J Mobile Communications, 3(3), 197-213.

Leppaniemi, M. \& Karjaluoto, H. 2008. Exploring the Effects of Gender, Age, Income and Employment Status on Consumer Response to Mobile Advertising Campaigns. Journal of Systems and Information Technology, 10(3), 251-265.

McCasland, M. 2005. Mobile Marketing to Millennials. Young Consumers, Quarter 2, 8-13.

Merisavo, M., Kajalo, S., Karjaluoto, H., Virtanen, V., Salmenkivi, S., Raulas, M. \& Leppaniemi, M. 2007. An Empirical Study of the Drivers of Consumer Acceptance of Mobile Advertising. Journal of
Interactive Advertising, 7(2), 41-50.

Mir, I. (2011). Consumer Attitude towards M-Advertising Acceptance: A Cross-Sectional Study. Journal of Internet Banking and Commerce, 16(1), 1-22.

Muzaffar, F. \& Kamran, S. 2011. SMS Advertising: Youth Attitude towards Perceived Informativeness, Irritation and Credibility. Interdisciplinary Journal of Contemporary Research in Business, 3(1), 230245.

Nysveen, H., Pedersen, P.E. \& Thorbjornsen, H. 2005. Intentions to Use Mobile Services: Antecedents and Cross-Service Comparisons. Journal of the Academy of Marketing Science, 33(3), 330-346.

Nysveen, H., Pedersen, P.E., Thorbjornsen, H. \& Berthon, P. 2005. Mobilizing the Brand: The Effects of Mobile Services on Brand Relationships and Main Channel Use. Journal of Service Research, 7(3), 257-276.

Oh, L. \& Xu, H. 2003. Effects of Multimedia on Mobile Consumer Behavior: An Empirical Study of Location-Aware Advertising. Twenty-Fourth International Conference on Information Systems.

Okazaki, S. \& Taylor, C.R. 2008. What is SMS Advertising and Why do Multinationals Adopt It? Answers from an Empirical Study in European Markets. Journal of Business Research, 61(1), 4-12.

Okazaki, S. 2005. Mobile Advertising Adoption by Multinationals: Senior Executives' Initial Responses. Internet Research, 15(2), 160-180.

Okazaki, S. (2005). New Perspectives on M-Commerce Research. Journal of Electronic Commerce Research, 6(3), 160-164.

Pajnik, M. \& Tusek, P.L. 2002. Observing Discourses of Advertising: Mobitel's Interpellation of Potential Consumers. Journal of Communication Inquiry, 26(3), 277-299.

Pavlou, P.A. \& Lie, T. 2006. What Drives Mobile Commerce? A Model of Mobile Commerce Adoption. Twenty Seventh International Conference on Information Systems.

Phau, I. \& Teah, M. 2009. Young Consumers' Motives for Using SMS and Perceptions towards SMS Advertising. Direct Marketing: An International Journal, 3(2), 97-108.

Radder, L., Pietersen, J., Wang, H. \& Han, X. 2010. Antecedents of South African High School Pupils' Acceptance of Universities' SMS Advertising. International Business and Economics Research Journal, 9(4), 29-40.

Rettie, R. \& Brum, M. 2001. M-Commerce: The Role of SMS Text Messages. COTIM-2001 Proceedings: From E-Commerce to M-Commerce. 
Reyck, B.D. \& Degraeve, Z. 2003. Broadcast Scheduling for Mobile Advertising. Operations Research, 51(4), 509-517.

Roach, G. 2009. Consumer Perceptions of Mobile Phone Marketing: A Direct Marketing Innovation. Direct Marketing: An International Journal, 3(2), 124138.

Saadeghvaziri, F. \& Hosseini, H.K. 2011. Mobile Advertising: An Investigation of Factors Creating Positive Attitude in Iranian Customers. African Journal of Business Management, 5(2), 394-404.

Saadeghvaziri, F. \& Seyedjavadain, S. 2011. Attitude toward Advertising: Mobile Advertising Vs Advertising-in-General. European Journal of Economics, Finance and Administrative Sciences, Issue 28, 104-114.

Salo, F., Sinisalo, F. \& Karjaluoto, H. 2008. Intentionally Developed Business Network for Mobile Marketing: A Case Study from Finland. Journal of Business and Industrial Marketing, 23(7), 497506.

Scharl, A., Dickinger, A. \& Murphy, J. 2005. Diffusion and Success Factors of Mobile Marketing. Electronic Commerce Research and Applications, 4, 159-173.

Sinisalo, J., Salo, J., Leppaniemi, M. \& Karjaluoto, H. 2005. Initiation Stage of Mobile Customer Relationship Management. The E-Business Review, 5, 205-209.

Sinisalo, J., Salo, J., Karjaluoto, H. \& Leppaniemi, M. 2006. Managing Customer Relationships through Mobile Medium- Underlying Issues and Opportunities. Proceedings of the 39th Hawaii International Conference on System Sciences.

Standing, C., Benson, S. \& Karjaluoto, H. 2005. Consumer Perspectives on Mobile Advertising and Marketing. ANZMAC Conference: Electronic Marketing.

Stump, R.L., Gong, W. \& Li, Z. 2008. Exploring the Digital Divide in Mobile-Phone Adoption Levels across Countries: Do Population Socioeconomic Traits Operate in the Same Manner as their Individual-Level Demographic Counterparts? Journal of Macromarketing, 28(4), 397-412.

Tan, S. J. \& Chia, L. 2007. Are We Measuring The Same Attitude? Understanding Media Effects on Attitude towards Advertising. Marketing Theory, 7(4), 353377.

Telecom Indicators. 2011. Pakistan Telecommunication Authority. Available online at: http://www.pta.
gov.pk/index.php?Itemid $=599, \quad$ accessed on Nov.16.2011.

Tsang, M.M., Ho, S. \& Liang, T. 2004. Consumer Attitudes toward Mobile Advertising: An Empirical Study. International Journal of Electronic Commerce, 8(3), 65-78.

Unni, R. \& Harmon, R. 2007. Perceived Effectiveness of Push Vs. Pull Mobile Location-Based Advertising. Journal of Interactive Advertising, 7(2), 28-40.

Waldt, D.L.R.V.D., Rebello, T.M. \& Brown, W.J. (2009). Attitudes of Young Consumers towards SMS Advertising, African Journal of Business Management, 3(9), 444-452.

Wang, T., Oh, L. \& Wang, K. 2009. Antecedents and Consequences of Mobile Advertising Intrusiveness. The 9th International Conference on Electronic Business.

Wang, A. \& Acar, S.A. 2006. Information Search and Mobile Promotions. International Journal of Mobile Marketing, 1(2), 80-87.

Wang, A. 2007. Branding Over Mobile and Internet Advertising: The Cross-Media Effect. International Journal of Mobile Marketing, 2(1), 34-42.

Wang, A. 2007. How Consumers Perceive Free Offers: Implications for Mobile Marketing. International Journal of Mobile Marketing, 2(2), 35-41.

Westell, S. \& Wessing, T. 2003. Lawful Data Processing for Email and SMS Marketing. Business Information Review, 20(3), 144-148.

Wehmeyer, K. 2007. Mobile Ad Intrusiveness - The Effects of Message Type and Situation. 20th Bled e-Conference e-Mergence: Merging and Emerging Technologies, Processes, and Institutions.

Wilken, R. \& Sinclair, J. 2009. 'Waiting for the Kiss of Life': Mobile Media and Advertising. Convergence: The International Journal of Research into New Media Technologies, 15(4), 427-445.

Wu, P.C.S. \& Wang, Y. 2011. The Influences of Electronic Word-Of-Mouth Message Appeal and Message Source Credibility on Brand Attitude. Asia Pacific Journal of Marketing and Logistics, 23(4), 448472.

Xu, H., Oh, L. \& Teo, H. 2009. Perceived Effectiveness of Text vs. Multimedia Location- Based Advertising Messaging. Int. J. Mobile Communications, 7(2), 154-177.

Zhang, H., Guerrero, C., Wheatley, D. \& Lee, Y.S. 2010. Privacy Issues and User A t t it u d e s towards Targeted Advertising: A Focus Group Study. Proceedings of the Human Factors and Ergonomics Society 54th Annual Meeting. 


\title{
IMPACT OF PERSONALITY ON ABSENTEEISM MODERATING ROLE OF ETHICAL ORIENTATION
}

\author{
MAHROASH MUNIR \\ Mirpur University of Science \& Technology, Mirpur, Azad Kashmir
}

\begin{abstract}
This study examined the impact of big five personality traits on absenteeism with moderating role of ethical orientation. Data was collected from 150 university faculty members across Pakistan using a questionnaire. Results indicate that big five personality traits to a large extent account for absenteeism while ethical orientation plays an important role as a moderator. Implications and future research directions are also discussed.
\end{abstract}

\section{INTRODUCTION}

Organizational Behavior and Human Resource researchers have studied absence from work and extensive research literature exits regarding it (Johns, 2003). Conventionally, absenteeism research has been focused on the 'lack of presence' characteristic of the behavior (Patton \& Johns, 2012). Previously tolerated behaviors of employees regarding absence in workplace is now unacceptable (Taylor, Cunningham, Newsome, \& Scholarios, 2010) because organizations which are experiencing high absenteeism bearing expensive cost.

Various studies focused on a broader range of determinants of absenteeism such as psychosocial work factors (Niedhammer, Chastang, Taieb, Vermeylen \& Thirion, 2012; Rugulies et al., 2007), Work characteristics (Griep, Rotenberg, Chor, Toivanen, \& Landsbergis, 2010), work-family role conflict (Lidwall, Marklund, \& Vos, 2009), and Job demand and resources (Schaufeli, Bakker, \& Rhenen, 2009). Among all these, job demands and resources work as analysts to forecast absence interval and rate in term of amount of absence and frequency (Bakker, Demerouti, Boer, \& Schaufeli, 2003). In addition, satisfactory psychosocial work environment strongly and independently effect sickness absence (Hansen et al., 2009). Latest work practices and faster technological innovations are altering the nature of jobs (Roelen, Koopmans, Bultmann, Groothoff \& Klink, 2009) resulting in increased rate of absenteeism. For avoiding sickness absence, variables like conflict, overload and improvement of role offer slight descriptive influence (Mastekaasa, 2000).

Besides these factors, specific personality traits of the employees may be correlated with absenteeism. The history of personality is a deep-rooted as the field of psychology. By mid-eighties, researchers started to unite manageable numbers of personality traits and models. Big Five Model of personality (Digman, 1990) was greatly accountable for the rebirth of research. Researchers in both psychology and organization behavior unified that the Big Five Model is a widely accepted framework of personality consisting of neuroticism, conscientiousness, extraversion, agreeableness, openness to experience (Digman, 1990), which allow to study meaningful relationships between personality traits and work behaviors.

In addition to information about personal and workplace attributes, personality act as an important descriptive factor for absenteeism (Stormer \& Fahr, 2013). The main personality variables (the Big 5 personality traits) effect was approximately as much as that of job attributes in employees with psychopathology, and even more than that of job features in physically fit employees as employees with high neuroticism, low extraversion, low agreeableness, low conscientiousness and low openness to experience will leads towards absenteeism (Vlasveld et al., 2013). In contrast, both neuroticism and related psychopathology were discovered to link with employee absence (Krispijn \& Bijl, 2000). Constancy of absenteeism eventually across varying environments may be because of its lasting, personality oriented determinants (Froggatt, 1970a, 1970b).

Inadequate former studies relied on the extent of the problem such as lost-time percentage and average number of spells per employee instead periods of long term sickness (Wright, 1997). Previously absenteeism was mostly assessed at team level instead of individual level (Consiglio, Borgogni, Alessandri \& Schaufeli, 2013). Limited work have been done to foresee absenteeism as a result of different personality traits, more specifically in 
Pakistan in term of long-term absence at both individual and team level. If variables of individual differences can be recognized to forecast absenteeism, then it may be probable to apply measures of these traits to select job candidates and in this manner absenteeism rate can be decreased (Ones, Viswesvaran \& Schmidt, 2003).

Ethical orientation also plays an important role to increase advantageous attitudes regarding employment (Valentine, Greller \& Richtermeyer, 2006). Ones et al. (2003) proposed that role of moderator should also be inspected in future between personality and absenteeism rather thansimply focusing on their bivariaterelationships. The significant aspect of this study is also to explore the moderating role of ethical orientation between personality-absenteeism relationships. In Pakistan minimum literature is available for ethical impact on the relationship of personality and absenteeism. Changing of context from developed countries to underdeveloped countries is the novelty for this study.

The findings of this paper will have important implications in educational industry to select professionals, more specifically teachers at university level, with such personality domains which forecasted low rate of absenteeism. For this purpose the personalitybased integrity tests can be used in personnel staffing decisions to assess relevant traits for predicting volunteer absenteeism. One of the advantages of this study is to help education sector to choose teachers with such personality traits that will reduce absenteeism in their workplaces and in this manner the main purpose of knowledge generation of this education industry can be attained. It also aims to advance literature in both theoretical and empirical manner by clarifying the moderating role of ethical orientation on personalityabsenteeism relationship.

\section{REVIEW OF LITERATURE}

\section{Relationship between Personality and Absenteeism}

The Big Five dimensions of personality such as neuroticism, extraversion, openness to experience, agreeableness and consciousness have received more attention than any other personality structure (Salgado \& Tauriz, 2014). The overall results showed in all studies of clinical symptoms of various disorders were associated with high neuroticism, weak conscientiousness, agreeableness, and low extraversion (Malouff, Thorsteinsson, \& Schutte, 2005).

Extraversion is related to the effort of the Status, conscientiousness was associated to success and the agreeableness was linked to efforts communion (Halbesleben \& Bowler, 2007; Hirschfeld, Lawson, \& Mossholder, 2004; Parks \& Guay, 2009). Autonomy and self-determination are linked to the openness to experience (Mount, Barrick, Scullen, \& Rounds, 2005). It was also shown that aspects of the Big Five were predictors of job related performance (Dudley, Orvis, Liebicki, \& Cortina, 2006).

Personality traits may affect the perception of their environment and attitudes about their great satisfaction and employee engagement work. These great attitudes are manifested in withdrawal behaviors that demonstrate a lack of willingness to be fully present in the workplace (Koslowsky, 2009).

\section{Relationship between Extraversion and Absenteeism}

The first factor is that the high activity extraversion, assertiveness and a tendency to social behavior (Furnham, Dissoy, Sloan, \& Chamorro-Premuzic, 2007; Erdheim, Wang, \& Zickar, 2006). Because of sociability, extroverts tend to have the trust of others (Zimmerman, 2008). They can affect their environment and are more motivated to achieve awards (Panaccio \& Vandenberghe, 2012). Studies show that the statues extroverts get more work in the long term and seek more success (George, Helson, \& John, 2011).

Lau, Au and Ho (2003) suggested that low job satisfaction related with absence from work. Extroverts achieve higher promotions, salaries, and greater job satisfaction (Sanders, 2008). For this reason, extroverts are more likely to become socialized into their organization and would be less likely to quit (Maertz \& Campion, 2004).

\section{Relationship between Agreeableness and Absenteeism}

The second factor is the agreeableness that is related to characteristics such as altruism, care and emotional support. People raised in agreeableness are more polite, adaptable, nice, cooperative, compassionate and patient (Erdheim et al., 2006). Staff with agreeable trait can help build trustworthy relations and contribute to team cohesion (Zimmerman, 2008). Their behavior is warm, liberal and supportive (Migliore, 2011). Agreeable employees admit changes more easily (Williamson, Pemberton, \& Lounsbury, 2008) and can contribute towards more capable employment (Zimmerman, 2008). However, such employees, while doing a good team player, often do not have enough experience to be successful in the world of work (Sanders, 2008). High agreeableness shows resilience with others; while low agreeableness relate to compete with others, and be willing to participate (Migliore, 2011).

Aspects of compliance and trust kindness is likely to cause employees to feel high agreeableness to identify contractual obligations to remain in the organization 
(Maertz \& Griffeth, 2004). People high in agreeableness are more flexible and conform expectations and rules and cannot be found hurt at work can also be seen as a reflection of the expectations and flexibility. Because of conflicts or job dissatisfaction, low agreeableness workers may have their own agenda at workplace, which can lead towards increased absenteeism (Vlasveld, 2013). Among healthy employees, low agreeableness were only associated with absenteeism (Malouff et al., 2005).

\section{Relationship between Conscientiousness and Absenteeism}

Conscientious individuals are more likely to perform the duties well. Execution of success in a role is likely to result in positive mood, increased selfesteem and appreciation of the partners to follow, and, therefore, facilitation (Wayne, Musisca, \& Fleeson, 2004). Conscientiousness is considered one of the most consistent predictors of personality and performance (Meyer, Dalal, \& Bonaccio, 2009; Barrick \& Mount, 2005)

Consciousness is composed of six smaller parts. The first aspect refers to the skill level of a person in dealing with the world. The second aspect, the command refers to the level of a single organization and control. The third component, duty, refers to the tendency of an individual to be reliable and trustworthy. The fourth aspect of the effort to achieve, focuses on the number of people who work hard to achieve their goals. The fifth aspect, selfdiscipline, it refers to a person's ability to perform tasks in the face of obstacles, such as boredom and distractions. The sixth aspect, the deliberation focuses on the amount of people who think before they act (Ekehammar \& Akrami, 2007). Research has shown that the six aspects of consciousness are differential predictive for other features. For example, a negative relationship exist between consciousness and fluid intelligence (Moutafi, Furnham, \& Paltiel, 2005; Moutafi, Furnham, \& Crump, 2006).

Low conscientiousness and absenteeism shows that workers with a great responsibility, planning and persistence have less absenteeism among low-skilled workers (Vlasveld, 2013). Therefore, Conscientiousness expected job absences (Lounsbury, Steel, Loveland, \& Gibson, 2004).

\section{Relationship between Neuroticism and Absenteeism}

The fourth factor is the neurosis that is associated with stress, irritability, and increased levels of anxiety (Sanders, 2008). The highly neurotic people are anxious, depressed, angry, emotional and insecure (Erdheim et al., 2006). They see the negative side of things and more can be considered neutral events as problematic; therefore tend to live less well - being and satisfaction and stress (Panaccio \& Vandenberghe, 2012). High scores on this factor showed reactive emotional behaviors associated with negative emotions such as anger or low morale; while low scores reflect the tranquility and the ability to manage stress (Migliore, 2011). In addition, neuroticism was directly related to transactional contracts, breach of contract perceived and experienced violation (Raja, Johns, \& Ntalianis, 2004).

A negative relationship exists between neuroticism and satisfaction (Judge, Higgins, Thoresen, \& Barrick, 1999) and between neuroticism and performance (Barrick \& Mount, 1991) in a wide variety of jobs. High level of anxiety, an important aspect of neurosis is negatively related to performance in complex tasks. Job satisfaction was negatively related to the number of sick leave days (Roelen, Koopmans, Notenbomer \& Groothoff, 2008). Cote (2005) hypothesize that people who have negative emotions (i.e., sadness and anger), are less likely to receive social support from colleagues and more likely to have interpersonal conflicts, which increases the levels of stress and increased their intention to leave. Happy employees are healthier and have a longer life expectancy.

Connolly and Myers (2003) also argue that job dissatisfaction has been associated with symptoms such as anxiety, depression and poor physical and psychological health, which have conjoined consequences for the absenteeism and commitment. Neuroticism has been shown to be associated with somatic symptoms medically unjustified, which may also lead towards absenteeism (Cuijpers et al., 2010). High neuroticism has confirmed work outcomes as absenteeism (Michon et al., 2013). In addition, neurotic people tend to be too many compromises that brings them take their work very seriously, for example, the work, even leisure time, but not necessary. While most of the company would lead to the absence of mental or physical illness (Vearing \& Mak, 2007). Neurotic people feel a lot of pressure in their work that the absence may be considered as coping strategy.

\section{Relationship between Openness to Experience and Absenteeism}

The last factor is the openness to experience, cope with change, innovation, new experiences and learning (Williamson et al., 2008). People with a greater openness to experience are creative, civil, curious, novel, open and intelligent mind (Erdheim et al., 2006). High scores on this factor showed great mental curiosity with creative thinking, while low scores indicate intent limited and cautious approach (Migliore, 2011). 
People high in openness are more in line with the expectations and standards and are more flexible, and cannot be reported illness at work can also be considered to meet the expectations and the flexibility of thought. According to the workers may also reflect openness have their own agenda, perhaps due to conflicts or job dissatisfaction, which can lead to high level of absenteeism (Vlasveld et al., 2013) .

Hardy, Woods and Walls (2003) found that job satisfaction is related to the number of days of absence, and the frequency of absences. Low openness to experience were associated with absenteeism among physically fit employees. As stated by Malouff et al. (2005), lower openness reflects classic, rigid and not open to new experiences. Direct effects on turnover suggest that individuals who are high in openness to experience can participate in spontaneous exit (Zimmerman, 2008).

In order to test this phenomena in Pakistani scenario of education sector, the current study has the following hypothesis:

\section{Hypothesis 1. There is a negative relationship between extraversion and absenteeism. \\ Hypothesis 2. There is a negative relationship between agreeableness and absenteeism. Hypothesis 3. There is a negative relationship between conscientiousness and absenteeism.} Hypothesis 4. There is a positive relationship between neuroticism and absenteeism.

Hypothesis 5. There is a negative relationship between openness to experience and absenteeism.

\section{Ethical Orientation as a Moderator between Personality and Absenteeism}

The ethical orientation is the set of beliefs that guide a person to distinguish right from wrong, good from evil, moral from immoral, aiding in the selection of an appropriate mode of behavior. Duchon and Drake (2009) define morality as the ability to make a judgment about the right and wrong organizational behavior, to adopt measures in accordance with the law. However, unethical behavior could be a consequence of the selfperception of a company; a consequence of how you define it.

Over the past two decades, a number of research studies have examined the ethical orientation of students, officials and other employees of different organizations and professions (Collins, 2000; Loe, Ferrel, \& Mansfield, 2000). There is an ethical problem arises when a decision made on one or more alternative that are inconsistent with ethical standards, or codes (Hunt \& Hansen, 2007). When an immoral action received, high idealists were more likely to lie as compared to low idealists (Allmon, Page, \& Roberts, 2000). To help develop an understanding of global ethics, it is necessary to inform people around the world and existing ethical perspectives to identify the determinants of ethical guidelines (Karande, Rao, \& Singhapakdi, 2002). Ethical orientation for employees can also influence interpretations and attitudes of organizational procedures and practices (Alder, Schminke, Noel, \& Kuenzi, 2008). From the ethical leaders have the potential to affect a wide range of individual results, organizational and social, it is more specifically important to understand the factors that influence the perception of the Executive Ethical Leadership (Jordan, Brown, Trevino, \& Finkelstein, 2013).

Values-based congruence is positively related to job satisfaction and organizational commitment and negatively associated with intention to quit (KristofBrown, Zimmerman, \& Johnson, 2005). Kinnicki, Mckee-Ryan, Shriesheim, \& Carson (2002) found that job satisfaction is positively related to the commitment, motivation and life satisfaction and negatively related to work and non-work stress, intention to leave, absenteeism and the actual rotation. Prottas (2008) suggests that employees and organizational performance can be affected by workers' perceptions of their managers to act in a reliable and ethical treatment of employees. Workers may need to impose physical or mental pain to another person as a way to help this person, another person, a working group, organization or society in general (Molinsky \& Margolis, 2005).

Selection and development of managers who have work ethic is important that the ethical misconduct can be costly and damaging to the reputation of managers and organizations. The instruments for measuring the Big Five are often used in selection (Kalshoven, Den Hartog, \& De Hoogh, 2011). Ethical Leadership and its development and promotion at all levels of management are high for many organizations, as it is expected that this type of leaders to have positive effects (Brown, Trevin, \& Harrison, 2005). Until now, research on the effects of ethics and related files of leadership behavior shows predominantly positive relationships with a variety of attitudes and behaviors of followers, such as commitment, satisfaction with the leader, trust the effectiveness of alleged leader and organizational citizenship behaviors (Brown et al., 2005; De Hoogh \& Den Hartog, 2008; Den Hartog \& De Hoogh, 2009; Mayer, Kuenzi, Greenbaum, Bardes, \& Salvador, 2009; Piccolo, Greenbaum, Den Hartog, \& Folger, 2010). Research shows that personal characteristics affect the influence of the leader (Anderson, Spataro, \& Flynn, 2008). The theory does not predict individual differences play a role in ethical issues (Brown \& Trevin, 2006). 
The previous literature has proposed various individual differences that are related to ethical leadership, including moral development, concern for people, reliability and accountability (Brown et al., 2005; Brown \& Trevin, 2006; De Hoogh \& Den Hartog, 2008). Integrity always correlate with agreeableness, conscientiousness, and emotional stability (Marcus, Hoft, \& Riediger, 2006; Ones, Viswesvaran, \& Dilchert, 2005). These three features are important for leaders to be perceived as ethical (Brown \& Trevin, 2006). Although three of the five main traits (agreeableness, conscientiousness, and emotional stability) are important to the history of ethical leadership (Brown \& Trevin, 2006; De Hoogh \& Den Hartog, 2009).

\section{Ethical Orientation as a Moderator between Extraversion and Absenteeism}

Extraversion wasnotapredictorofunethical behavior. Highly socially responsible leaders are recognized as more ethical. Furthermore, Mayer et al. (2009) found that moral identity is associated with ethical leadership. The agreeableness and justice refers to the element that reflects the simplicity of being honest, sincere and honest in dealings with others behaving fairly (Costa, McCrae, \& Dye, 1991). Zhao and Siebert (2006) include the people depicting the agreeableness trait are those who are co-operative and prefer positive interpersonal relationships. Highly agreeableness person is bounded to fear. The fear of being punished for not following the law, policy or procedure, is a decent honest trustworthy person. Thus, it employees high on this score ignore in being engaged in unethical behaviors.

\section{Ethical Orientation as a Moderator between Agreeableness and Absenteeism}

Agreeableness has strong relationship with job satisfaction and the lack of agreeableness is related to deviant behavior such as antisocial behavior in nonprofessional settings (Mount, Ilies, \& Johnson, 2006). Low agreeableness shows low score on issues such as modesty, respect, cooperation and trust (Malouff et al., 2005). People who depict agreeableness traits are those who have a fear of being punished for not complying with laws and it makes a person honest, decent and trustworthy (Zhao \& Siebert, 2006). Agreeableness and fairness reflects honesty, sincerity, and truthfulness in dealing with others which implies behaving fairly (Costa, McCrae, \& Dye, 1991). Walumbwa and Schaubroeck (2009) found that there is a positive relationship exist between agreeableness and ethical leadership.

\section{Ethical Orientation as a Moderator between}

\section{Conscientiousness and Absenteeism}

Highly conscientious people tend to think before they act and strictly fulfill their legal obligations and responsibilities (Costa and McCrae, 1992). The responsible, reliable and voluntary elements of consciousness make people to perform right thing, not only for themselves but also for others. It is expected that high consciousness leaders behave in a consistent manner and treat subordinates consistently (Mayer, Nishii, Schneider, \& Goldstein 2007). Executives with high conscientiousness are less likely to show favoritism among employees. In this way, they follow the rules and work without problems.

The literature has ever reported a positive relationship between consciousness and ethics through both academic and professional scenario. Williams et al. (2010) also found that high conscientiousness is negatively related with self-reported cheating. Work related ethic was positively correlated with success, linked to the centrality of the person in the hard work to produce desirable results (Mudrack, 1992). This pattern of results suggests that the high conscientiousness includes proactive components and, therefore, provides evidence of the ethical dimension of the discriminant validity of work (Miller, Woehr, \& Hudspeth, 2002).

With regard to the moral/ethical aspects, Christopher, Zabel, \& Jones (2008) found that the sense of duty and competition would provide morality or ethics. Having the ability to face the world allow one to live honestly. Willingness to complete may indicate a strong ethics of respondents (Cokley et al., 2007). Walumbwa and Schaubroeck (2009) found a positive relationship between conscientiousness and ethical leadership.

Ethical Orientation as a Moderator between Neuroticism and Absenteeism

Neurotic people tend to be less reliable and more prone to high levels of stress, motivation of unethical behavior can give more in their desire to avoid the failure of success (Barrick, Mount, \& Li, 2013). High levels of neuroticism surveillance with high levels of perceived stress led to an increase in the perception of bullying in the workplace of employees (Mathisen, Einarsen, \& Mykletun, 2011). Deviation and the interpersonal work has a strong relationship with high levels of neuroticism (Berry, Ones, \& Sackett, 2007). Xu, Yu, and Shi (2011) found high levels of neuroticism and a negative relationship to ethical leadership.

Neurotic leaders are less likely to communicate honestly and openly about their expectations for their subordinates (Kalshoven et al., 2011). Brown and Trevin (2006) suggest a negative relationship between neurosis and ethical leadership and, they also expect less perception of ethical behavior with neurotic individuals. 
Ethical Orientation as a Moderator between Openness to Experience and Absenteeism

Kalshoven et al. (2011) have suggested that openness to experience was not related to ethical behavior. Added individualization is characterized by fairness and ensure that individuals are protected against damage. This value is significantly associated with openness to experience. Moral behavior varies according to five main bases: damage (minimum damage to others), justice (maximizing fairness for all), in group loyalty (the importance of team work), authority (respect for the rule and the hierarchy) and purity (avoid unpleasant entities). These five aspects of morality, in turn, are connected to form two major factors of moral order individualizationtotal score on the harm and fairness and binding-the total score for authority, loyalty to the group, and purity (Graham et al ., 2009). Lewis and Bates (2011) predicts a negative association between openness and binding and a positive link between openness and individualization.

Based upon the past studies, the following study has concluded that ethical orientation can act as a moderator which can influence the relationship between personality traits and absenteeism. Hence, the current study has incorporated following hypothesis:

\section{Hypothesis 6. Ethical orientation moderates the relationship between extraversion and absenteeism. \\ Hypothesis 7. Ethical orientation moderates the relationship between agreeableness and absenteeism. \\ Hypothesis 8. Ethical orientation moderates the relationship between conscientiousness and absenteeism. \\ Hypothesis 9. Ethical orientation moderates the relationship between neuroticism and absenteeism. Hypothesis 10. Ethical orientation moderates the relationship between openness to experience and absenteeism.}

\section{METHODOLOGY}

\section{Sample and Procedure}

The sample comprised of employees working in wellestablished private and public sector universities located in Pakistan. A total of four universities, including Iqra University, Allama Iqbal Open University, International Islamic University and Quaid-e-Azam University, were selected. Research access was possible by using personal contacts. Questionnaires were distributed to teachers working in above mention universities. From 300 questionnaires, 170 were returned and only 150 were completed to use in the study from which 60 responses were returned from Iqra University, 25 from Allama Iqbal Open University, 30 from Quaid-e-Azam University and 35 from International Islamic University. 82 percent respondents were males. Overall response rate was 50 percent. Education levels ranged from bachelor to receiving a Ph.D., with 10 percent of the respondents having bachelor certificate and the remaining 90 percent having Masters, MS or PhD degrees.

\section{Measures}

All measures were obtained from a "self-report" questionnaire. To measure the independent variable that is personality traits, scale adopted by Rammstedt, and John (2007) having reliability of .735 has been used. The scale is a short version of Big Five Inventory. For instance, items included as "Is outgoing, sociable" for extraversion, "Does a thorough job" for conscientiousness, "Gets nervous easily" for neuroticism, "Is generally trusting" for agreeableness and "Has an active imagination" for openness to experience. To measure the dependent variable that is absenteeism, the questionnaire adopted by Katou and Budhwar (2006). Respondents were asked to specify there level of agreement or disagreement with statements as "Remaining absent from the job will be the first option if something important comes up". Coefficient alpha for this scale was .716. For mediator that is ethical orientation, scale of Ethics Position Questionnaire (EPO) of Forsvth (1980) were used with reliability score as .756 having items such as "Influential", "Principled", and "trustworthy". Each scale included in the questionnaire measures the responses on seven-point Likert scale where 1 represent strong disagreement and 7 represent strong agreement with the items excluding personality traits with five-point Likert scale. To make it easy for analysis all scales converted on five-point Likert scale where 1 represents "strongly disagree" and 5 represents "strongly agree". Questionnaire is in English language as university teachers are able to understand it so there is no need to translate into native language.

\section{Control variables}

Age, gender, qualifications and experience were used as control variables because they have impact on personality, absenteeism and orientation of ethics. To check the actual relationship these variables serves as control variables.

\section{RESULTS}

Table 1 presents descriptive statistics and correlations among the variables such as personality traits, absenteeism 
and ethical orientation. The mean for absenteeism was 2.91 and ethical orientation was 3.93, extraversion was 2.98 , conscientiousness was 2.97 , neuroticism was 2.88 , agreeableness was 3.07 , and openness to experience was 3.72. The correlation between absenteeism and extraversion, conscientiousness, neuroticism and agreeableness was $-.167^{*},-.166^{*},-.098^{*},-.193^{*}$ and $-.237 * *(* * \mathrm{P}<.01, * \mathrm{P}<.05)$ respectively.

TABLE 1

Means, Standard Deviations, Correlations, and Reliabilities

\begin{tabular}{lcccccc}
\hline Variable & Mean & SD & $\mathbf{1}$ & $\mathbf{2}$ & $\mathbf{3}$ & $\mathbf{4}$ \\
\hline 1. Absenteeism & 2.91 & 1.13 & & & & \\
2. Ethical Orientation & 3.93 & .40 & $-.265^{* *}$ & & & \\
3. Extraversion & 2.98 & .90 & $-.167^{*}$ & $.041^{*}$ & & \\
4. Conscientiousness & 2.97 & .77 & $-.166^{*}$ & $.105^{*}$ & $.461^{* *}$ & \\
5. Neuroticism & 2.88 & .77 & $-.098^{*}$ & $.143^{*}$ & $.429^{* *}$ & $.382^{* *}$ \\
6. Agreeableness & 3.07 & .79 & $-.193^{*}$ & $.045^{*}$ & $.443^{* *}$ & $.560^{* *}$ \\
7. Openness to Experience & 3.72 & .98 & $-.237^{* *}$ & $.314^{* *}$ & $.404^{* *}$ & $.497^{* *}$ \\
\hline
\end{tabular}

*. Correlation is significant at the 0.05 level (2-tailed).

**. Correlation is significant at the 0.01 level (2-tailed).

\section{Regression Analyses}

Hierarchical regression analyses is performed to test the hypotheses. In the first step age, gender, qualification, and experience were entered as control variables in regressions. The hypotheses predict that extraversion, conscientiousness, agreeableness, and openness will be negatively related to absenteeism and neuroticism will be positively linked with absenteeism. To test these predictions, we regressed absenteeism on the Big Five traits (see Table 2). Conscientiousness and neuroticism were positively related with absenteeism. However, extraversion, agreeableness, and openness were negatively related with absenteeism. Thus hypothesis $\mathrm{H}_{1}, \mathrm{H}_{2}, \mathrm{H}_{4}$ and $\mathrm{H}_{5}$ accepted and $\mathrm{H}_{3}$ rejected.

TABLE 2

Hierarchical Regression analysis for Personality traits, absenteeism and ethical orientation

\begin{tabular}{cccc}
\hline Predictor & \multicolumn{3}{c}{ Absenteeism } \\
& $\boldsymbol{\beta}$ & $\mathbf{R}^{2}$ & $\Delta \mathbf{R}^{2}$ \\
\hline
\end{tabular}

Step 1

Control Variables .145

Step 2

\begin{tabular}{llll} 
Extraversion & $-.024 *$ & & \\
Conscientiousness & $.010^{*}$ & & \\
Neuroticism & $.034^{*}$ & & \\
Agreeableness & $-.049 *$ & & \\
Openness to experience & $-.146 *$ & .180 & .036 \\
\hline$* * P<0.01, * * P<0.05 ; n=150$ &
\end{tabular}

\section{Ethical Orientation as a Moderator}

Moderated regression analysis was used to examine the interactive effects of ethical orientation and personality traits on absenteeism. Controlling for extent of ethical orientation, this test examined that the specific personality traits react more strongly in terms of absenteeism. First, control variables were entered into the model. In the second step, we entered personality traits along with ethical orientation to predict absenteeism. Then, in the last step, the interaction terms between ethical ownership and personality were entered.

The results, presented in Table 3 , shows that interaction terms for extraversion, conscientiousness, and openness have a negative and neuroticism and agreeableness have a positive and insignificant impact on absenteeism.

TABLE 3

Moderator Regression analysis for Ethical Orientation

\begin{tabular}{cccc}
\hline Predictor & \multicolumn{3}{c}{ Absenteeism } \\
& $\boldsymbol{\beta}$ & $\mathbf{R}^{2}$ & $\Delta \mathbf{R}^{2}$ \\
\hline
\end{tabular}

Step 1

Control Variables $\quad .145$

Step 2

$-.048$

Conscientiousness

.015

Neuroticism

.000

Agreeableness

Openness to experience

$-.051$

Ethical Orientation

$-.217$

.220

.075

Step 3

Extraversion X Ethical

Orientation

$-.105$

.224

.004

Conscientiousness X

$-.330$

.229

.009

Ethical Orientation 


\begin{tabular}{lccc}
$\begin{array}{l}\text { Neuroticism X Ethical } \\
\text { Orientation }\end{array}$ & .015 & .221 & .001 \\
$\begin{array}{l}\text { Agreeableness X Ethi- } \\
\text { cal Orientation }\end{array}$ & .109 & .223 & .003 \\
$\begin{array}{l}\text { Openness to experience } \\
\text { X Ethical Orientation }\end{array}$ & -.361 & .225 & .005 \\
\hline$* * * P<0.01, * * P<0.05 ; n=150$ & &
\end{tabular}

\section{DISCUSSION}

Objective of the study was to explore the relationship between personality traits and absenteeism by analyzing moderating role of ethical orientation. Results of the study indicates that four hypotheses are accepted having a negative relationship between extraversion, agreeableness, openness to experience and absenteeism and a positive relation between neuroticism and absenteeism. Raja, Johns, \& Ntalianis, (2004) stated that a negative relationship exist between relational contracts and neuroticism and a positive relationship between relational contracts and extraversion. So neurotic employees lead towards more absence as compared to extraverted employees. Happy extravert, agreeable and non-neurotic employees perform well in their job-setting and experience higher job satisfaction in collectivistic Asian society (Templer, 2012) and if employees are more satisfied with their jobs, then absenteeism will be reduces. So it confirms hypothesis as there is a negative relationship exist between agreeableness, extraversion and absenteeism and a positive relationship between neuroticism and absenteeism. Employees with low openness to experience were more associated with absenteeism (Malouff et al., 2005), thus confirming the results regarding openness to experience. In short, these results support the prior findings and literatures.

Whereas a positive relationship exist between conscientiousness and absenteeism instead of negative relationship. As Lounsbury, Steel, Loveland, and Gibson, (2004) confirms that conscientiousness expected absenteeism due to a great responsibility, planning and persistence. So a positive relationship can exist between conscientiousness and absenteeism.

More worrisome, the data did not support hypotheses 6 to 10 concerning the role of moderator i.e., ethical orientation on the relationship of personality big five inventory and absenteeism. In Pakistani context, employees are less concerning about job ethics. They only follow ethics when they are bound in their jobs and observed by superior authority. So in this scenario ethics are unable to strengthen or weaker their relationships between specific personality types and absenteeism. Pakistan is a highest score country on power distance (Aycan et al., 2000), one of the culture dimension of Hofstede (1980). Heine, Lehman, Markus, and Kitayama
(1999) assumed that people try to find positive selfregard which may harm interest and violate rights of others. An extensive positive personal characteristics found with those who self-regard or who have a strong superiority sense (Taylor \& Brown, 1988). Higher levels of self-regard were more stereotypically masculine i.e., assertive, tough, and focused on material success (Bond, Kwan, \& Li, 2000). So superiority in terms of power distance may be a reason due to which people in Pakistani context emphasize low in terms of ethical orientation.

Another reason is that individuals are biased when they have to evaluate themselves. No one declare him or her as less innovative or hard worker. Moreover, they don't admit that they are least concerning about their work. So responses also affect nature of study as stated by Aycan et al. (2000) that Pakistan is an underresearched country.

One limitation of this study is the small sample size. Whereas sample size of 150 reduced power of statistical analyses and limited generalizability. Secondly, data is gathered using questionnaire only, mixed methods validate results more specifically. Thirdly, data is collected by different teachers at university and college level about their performance, and individuals can be biased as no one declare him/her as a bad performer. Fourthly, it is industry specific as only focused on education industry and lastly, this is not a longitudinal research.

Policy makers in education sector can use this study to improve employee's performance by providing decentralized structures and give employees a sense of psychological ownership with organization. As in case of centralized structures autonomy is concentrated at top management levels and in this case employee's performance can be affected due to lack of psychological ownership.

The findings of this paper will have important implications in educational industry to select professionals using personality-based integrity tests in personnel staffing decisions to assess personality traits that leads towards volunteer absenteeism.

In the future, researchers will consider multiple sources of information when making assessments of personality big five traits and absenteeism. Along with personality traits other variables such as workload, stress, and autonomy can be used to check impact on absenteeism. This relationship can be validated in future using moderator i.e, ethical orientation in other context to confirm results of this study.

\section{REFERENCES}

Alder, G. S., Schminke, M., Noel, T. W., \& Kuenzi, M. 
2008. Employee reactions to internet monitoring: the moderating role of ethical orientation. Journal of Business Ethics, 80(3), 481-498.

Allmon, D. E., Page, D., \& Rpberts, R. 2000. Determinants of perceptions of cheating: Ethical orientation, personality and demographics. Journal of Business Ethics，23(4), 411-422.

Anderson, C., Spataro, S. E., \& Flynn, F. J. 2008. Personality and organizational culture as determinants of influence. Journal of Applied Psychology, 93(3), 702.

Aycan, Z., Kanungo, R., Mendonca, M., Yu, K., Deller, J., Stahl, G., \& Kurshid, A. 2000. Impact of culture on human resource management practices: A 10country comparison. Applied Psychology, 49(1), 192-221.

Bakker, A. B., Demerouti, E., de Boer, E. D.,\& Schaufeli, W. B. 2003. Job demands and job resources as predictors of absence duration and frequency. Journal of Vocational Behavior, 62, 341-356.

Barrick, R. M., \& Mount, M. K. 1991. The Big Five personality dimensions and job performance: A meta-analysis. Personnel Psychology, 44, 1-26.

Barrick, M. R., \& Mount, M. K. 2005. Yes, personality matters: Moving on to more important matters. Human Performance, 18, 359-372.

Barrick, M. R., Mount, M. K., \& Li, N. 2013.The theory of purposeful work behavior: The role of personality, higher-order goals, and job characteristics. Academy of Management Review, 38(1), 132-153.

Berry, C. M., Ones, D. S., \& Sackett, P. R. 2007. Interpersonal deviance, organizational deviance, and their common correlates: a review and metaanalysis. Journal of Applied Psychology, 92(2), 410.

Bond, M. H., Kwan, V. S., \& Li, C. 2000. Decomposing a sense of superiority: The differential social impact of self-regard and regard for others. Journal of Research in Personality, 34(4), 537-553.

Brown, M. E., Treviño, L. K., \& Harrison, D. A. 2005. Ethical leadership: A social learning perspective for construct development and testing. Organizational Behavior and Human Decision Processes, 97(2), 117-134.

Brown, M. E., \& Treviño, L. K. 2006. Ethical leadership: A review and future directions. The Leadership Quarterly, 17(6), 595-616.

Christopher, A. N., Zabel, K. L., \& Jones, J. R. 2008. Conscientiousness and Work Ethic Ideology. Journal of Individual Differences, 29(4), 189-198.

Cokley, K., Komarraju, M., Pickett, R., Shen, F., Patel, N., Belur, V., \& Rosales, R. 2007. Ethnic differences in endorsement of the Protestant work ethic: The role of ethnic identity and perceptions of social class. The Journal of social psychology, 147(1), 75-89.

Collins, D. 2000. The quest to improve the human condition: The first 1500 articles published in Journal of Business Ethics. Journal of Business ethics, 26(1), 1-73.

Connolly, K., \& Myers, E. 2003. Wellness and mattering: the role of holistic factors in job satisfaction. Journal of Employment Counseling, 40(4), 287 295.

Consiglio, C., Borgogni, L., Alessandri, G., \& Schaufeli, W. B. 2013. Does self-efficacy matter for burnout and sickness absenteeism? The mediating role of demands and resources at the individual and team levels. Work \& Stress, 27(1),22-42.

Costa Jr, P. T., McCrae, R. R., \& Dye, D. A. 1991. Facet scales for agreeableness and conscientiousness: a revision of the NEO personality inventory. Personality and Individual Differences, 12(9), 887898.

Costa Jr, P. T., \& McCrae, R. R. 1992. Four ways five factors are basic. Personality and individual differences, 13(6), 653-665.

Cote, S. 2005. A social interaction model of the effects of emotion regulation on work strain. Academy of Management Review, 30(3), 509-530.

Cuijpers, P., Smit, F., Penninx, B. W., de Graaf, R., ten Have, M., \& Beekman, A. T. 2010. Economic costs of neuroticism: a population-based study. Archives of General Psychiatry, 67(10), 1086-1093.

De Hoogh, A. H., \& Den Hartog, D. N. 2008. Ethical and despotic leadership, relationships with leader's social responsibility, top management team effectiveness and subordinates' optimism: A multimethod study. The Leadership Quarterly, 19(3), 297-311.

Den Hartog, D. N., \& DeHoogh, A. H. 2009. Empowering behavior and leader fairness and integrity: Studying perceptions of ethical leader behavior from a levelsof-analysis perspective. European Journal of Work and Organizational Psychology, 18(2), 199-230.

Digman, J. M. (1990). Personality structure: Emergence of the five-factor model. Annual Review of Psychology, 41, 417-440.

Duchon, D., \& Drake, B., 2009. Organizational Narcissism and Virtuous Behavior. Journal of Business Ethics, 85, 301-308.

Dudley, N. M., Orvis, K. A., Lebiecki, J. E., \& Cortina, J. M. 2006. A meta-analytic investigation of conscientiousness in the prediction of job performance: examining the intercorrelations and the incremental validity of narrow traits. Journal of Applied Psychology, 91(1), 40. 
Ekehammar, B., \& Akrami, N. 2007. Personality and prejudice: From big five personality factors to facets. Journal of Personality, 75, 899-725.

Erdheim, J., Wang, M., \& Zickar, M. J. 2006. Linking the Big Five Personality constructs to organizational commitment. Personality and Individual Differences, 41, 959-970.

Froggatt, P. 1970a. Short-term absence from industry I Literature, definitions, data and the effect of age and length of service. British Journal of Industrial Medicine, 27, 199-210.

Froggatt, P. 1970b. Short-term absence from industry II Temporal variation and inter-association with other recorded factor. British Journal of Industrial Medicine, 27, 211-224.

Furnham, A., Dissou, G., Sloan, P., \& ChamorroPremuzic, T. 2007. Personality and intelligence in business people: A study of two personality and two intelligence measures. Journal of Business and Psychology, 22(1), 99-109.

George, L. G., Helson, R., \& John, O. P. 2011. The "CEO" of women's work lives: How Big Five Conscientiousness, Extraversion, and Openness predict 50 years of work experiences in a changing socio-cultural context. Journal of Personality and Social Psychology, 101(4), 812.

Graham, J., Haidt, J., \& Nosek, B. A. 2009. Liberals and conservatives rely on different sets of moral foundations. Journal of Personality and Social Psychology, 96, 1029-1046.

Griep, R. H., Rotenberg, L., Chor, D., Toivanen, S., \& Landsbergis, P. 2010. Beyond simple approaches to studying the association between work characteristics and absenteeism: Combining the DCS and ERI models. Work \& Stress, 24(2), 179195.

Halbesleben, J. R. B., \& Bowler, W. M. 2007. Emotional exhaustion and job performance: The mediating role of motivation. Journal of Applied Psychology, 92, 93-106.

Hansen, T. M., Wieclaw, J., Agerbo, E., Nielson, N. W., Rosenkilde, M., \& Bonde, J. P. 2009. Sickness absence and workplace levels of satisfaction with psychological work conditions at public service work places. American Journal of Industrial Medicine, 52, 153-161.

Hardy, G. E., Woods, D., \& Wall, T. D. 2003. The impact of psychological distress on absence from work. Journal of Applied Psychology, 88(2), 306.

Heine, S. J., Lehman, D. R., Markus, H. R., \& Kitayama, S. 1999. Is there a universal need for positive selfregard?. Psychological review, 106(4), 766.

Hirschfeld, R. R., Lawson, L., \& Mossholder, K. W. 2004. Moderators of the relationship between cognitive ability and performance: General versus context-specific achievement motivation. Journal of Applied Social Psychology, 34, 2389-2409.

Hofstede, G. 1980. Culture's consequences: International differences in work-related values, Beverly Hills, CA: Sage.

Hunt, S.D., \& Hansen, J.M. 2007. Understanding ethical diversity in organizations. Organizational Dynamics, 36, 202-216.

Johns, G. 2003. How methodological diversity has improved our understanding of absenteeism from work. Human Resource Management Review, 13 (2), 157-184.

Jordan, J., Brown, M. E., Trevino, L. K., \& Finkelstein, S. 2013. Someone to Look Up To ExecutiveFollower Ethical Reasoning and Perceptions of Ethical Leadership. Journal of Management, 39(3), 660-683.

Judge, T. A., Higgins, C. A., Thoresen, J. C., \& Barrick R. M. 1999. The Big Five personality traits, general mental ability, and career success across the life span. Personnel Psychology, 52, 621-652.

Kalshoven, K., Den Hartog, D. N., \& De Hoogh, A. H. 2011. Ethical leader behavior and big five factors of personality. Journal of Business Ethics, 100(2), 349-366.

Karande, K., Rao, C. P., \& Singhapakdi, A. 2002. Moral philosophies of marketing managers: A comparison of American, Australian, and Malaysian cultures. European Journal of Marketing, 36(7/8), 768-791.

Kinicki, A. J., McKee-Ryan, F. M., Schriesheim, C. A., \& Carson, K. P. 2002. Assessing the construct validity of the job descriptive index: a review and meta-analysis. Journal of Applied Psychology, 87(1), 14.

Koslowsky, M. 2009. A multi-level model of withdrawal: Integrating and synthesizing theory and findings. Human Resource Management Review, 19(4), 283-303.

Krispijn, S. L. \& Bijl, R. V. 2000. Mental disorders and employee sickness absence: the NEMESIS study. Social psychiatry and psychiatric epidemiology, 35(2), 71-77.

Kristof-Brown, A. L., Zimmerman, R. D., \& Johnson, E. C. 2005. Consequences of Individuals' Fit at Work: A Meta-Analysis of Person-Job, PersonOrganization,Person-Group, andPerson-Supervisor Fit. Personnel psychology, 58(2), 281-342.

Laitinen-Krispijn, S., \& Bijl, R. V. 2000. Mental disorders and employee sickness absence: the NEMESIS study. Social Psychiatry and Psychiatric epidemiology, 35(2), 71-77.

Lau, V.C., Au, W.T., \& Ho, J.M. 2003. A qualitative and quantitative review of antecedents of 
counterproductive behavior in organizations. Journal of Business and Psychology, 18(1), 73-93.

Lewis, G. J., \& Bates, T. C. 2011. From left to right: How the personality system allows basic traits to influence politics via characteristic moral adaptations. British Journal of Psychology, 102(3), 546-558.

Lidwall, U., Marklund, S., \& Voss, M. 2009. Workfamily interference and long- term sickness absence: a longitudinal cohort study. European Journal of Public Health, 20(6), 676-681.

Loe, T. W., L. Ferrel \& P. Mansfield 2000. A Review of Empirical Studies Assessing Ethical

Decision making in Business, Journal of Business Ethics, 25(3), 185-204.

Lounsbury, J. W., Steel, R. P., Loveland, J. M., \& Gibson, L. W. 2004. An investigation of personality traits in relation to adolescent school absenteeism. Journal of Youth and Adolescence, 33(5), 457-466.

Maertz CP, Griffeth RW. 2004. Eight motivational forces and voluntary turnover: A theoretical synthesis with implications for research. Journal of Management, 30, 667-683.

Maertz CP, Campion MA. 2004. Profiles in quitting: Integrating process and content turnover theory. Academy of Management Journal, 47, 566-582.

Malouff, J. M., Thorsteinsson, E. B., \& Schutte, N. S. 2005. The relationship between thefive-factormodel of personality and symptoms of clinical disorders: A meta-analysis. Journal of Psychopathology and Behavioral Assessment, 27(2), 101-114.

Marcus, B., Hoft, S., \& Riediger, M. 2006. Integrity tests and the five-factor model of personality: A review and empirical test of two alternative positions. International Journal of Selection and Assessment, 14(2), 113-130.

Mastekaasa, A. 2000. Parenthood, gender and sickness absence. Social Science \& Medicine, 50, 18271842.

Mathisen, G. E., Einarsen, S., \& Mykletun, R. 2011. The relationship between supervisor personality, supervisors' perceived stress and workplace bullying. Journal of business ethics, 99(4), 637651.

Mayer, D., Nishii, L., Schneider, B., \& Goldstein, H. 2007. The precursors and products of justice climates: Group leader antecedents and employee attitudinal consequences. Personnel Psychology, 60(4), 929-963.

Mayer, D. M., Kuenzi, M., Greenbaum, R., Bardes, M., \& Salvador, R. B. 2009. How low does ethical leadership flow? Test of a trickle-down model. Organizational Behavior and Human Decision Processes, 108(1), 1-13.
Meyer, R. D., Dalal, R. S., \& Bonaccio, S. 2009. A metaanalytic investigation into the moderating effects of situational strength on the conscientiousness performance relationship. JournalofOrganizational Behavior, 30(8), 1077-1102.

Michon, H. W. C., Ten Have, M., Kroon, H., Van Weeghel, J., De Graaf, R., \& Schene, A. H. 2013. Mental disorders and personality traits as determinants of impaired work functioning. Psychological medicine, 38(11), 1627.

Migliore, L. A. 2011. Relation between big five personality traits and Hofstede's cultural dimensions: Samples from the USA and India. Cross Cultural Management: An International Journal, 18(1), 38-54.

Miller, M. J., Woehr, D. J., \& Hudspeth, N. 2002. The meaning and measurement of work ethic: Construction and initial validation of a multidimensional inventory. Journal of Vocational Behavior, 60(3), 451-489.

Molinsky, A., \& Margolis, J., 2005. Necessary evils and interpersonal sensitivity in organizations. Academy of Management Review, 30, 245-268.

Mount, M. K., Barrick, M. R., Scullen, S. M., \& Rounds, J. 2005. Higher-order dimensions of the Big Five personality traits and the Big Six vocational interest types. Personnel Psychology, 58, 447-478.

Mount, M., Ilies, R., \& Johnson, E. 2006. Relationship of personality traits and counterproductive work behaviors: The mediating effects of job satisfaction. Personnel Psychology, 59(3), 591-622.

Moutafi, J., Furnham, A., \& Paltiel, L. 2005. Can personality and demographic factors predict intelligence? Personality and Individual Differences, 38, 1021-1033.

Moutafi, J., Furnham, A., \& Crump, J. 2006. What facets of openness and conscientiousness predict fluid intelligence score? Learning and Individual Differences, 16, 31-42.

Mudrack, P. E. 1992. 'Work' or 'leisure'? The Protestant work ethic and participation in an employee fitness program. Journal of Organizational Behavior, 13(1), 81-88.

Munch-Hansen, T., Wieclaw, J., Agerbo, E., WestergaardNielsen, N., Rosenkilde, M., \& Bonde, J. P. 2009. Sickness absence and workplace levels of satisfaction with psychosocial work conditions at public service workplaces. American Journal of Industrial Medicine, 52(2), 153-161.

Niedhammer, I., Chastang, J. F., Sultan-Taieb, H., Vermeylen, G., \& Parent-Thirion, A. 2012. Psychosocial work factors and sickness absence in 31 countries in Europe. The European Journal of Public Health, 23(4), 622-629. 
Ones, D. S. 2005. Personality at work: Raising awareness and correcting misconceptions. Human Performance, 18(4), 389-404.

Ones, D. S. Viswesvaran, C., \& Schmidt, F. L. 2003. Personality and absenteeism: A meta-analysis of integrity test. European Journal of Personality, 17, S19-S38.

Panaccio, A., \& Vandenberghe, C. 2012. Fivefactor model of personality and organizational commitment: The mediating role of positive and negative affective states. Journal of Vocational Behavior, 80(3), 647-658.

Parks, L., \& Guay, R. P. 2009. Personality, values, and motivation. Personality and Individual Differences, 47, 675-684.

Patton, E., \& Johns, G. 2012. Context and the social representation of absenteeism: Absence in the popular press and in academic research. Human Relations, 65(2), 217-240.

Piccolo, R. F., Greenbaum, R., Hartog, D. N. D., \& Folger, R. 2010. The relationship between ethical leadership and core job characteristics. Journal of Organizational Behavior, 31(2-3), 259-278.

Prottas, D. J. 2008. Perceived behavioral integrity: Relationships with employee attitudes, well-being, and absenteeism. Journal of Business Ethics, 81(2), 313-322.

Raja, U., Johns, G., \& Ntalianis, F. 2004. The impact of personality on psychological contracts. Academy of Management Journal, 47(3), 350-367.

Roelen, C. A. M., Koopmans, P. C., Bultmann, U., Groothoff, J. W., \& van der Klink, J. J. L. 2009. Psychological work conditions and registered sickness absence: a 3-year prospective cohort study among office employees. International Archieves of Occupational and Environment Health, 82, 1107-1113.

Roelen, C. A. M., Koopmans, P. C., Notenbomer, A., \& Groothoff, J. W. 2008. Job satisfaction and sickness absence: a questionnaire survey. Occupational Medicine, 58(8), 567-571.

Rugulies, R., Christensen, k. B., Borritz, M., Villadsen, E., Bultmann, U., \& Kristensen, T. S. 2007. The contribution of the psychosocial work environment to sickness absence in human service workers: Results of a 3-year follow-up study. Work \& Stress, 21(4), 293-311.

Salgado, J. F., \& Tauriz, G. 2014. The Five-Factor Model, forced-choice personality inventories and performance: A comprehensive meta-analysis of academic and occupational validity studies. European Journal of Work and Organizational Psychology, 1-28.
Sanders, B. A. 2008. Using personality traits to predict police officer performance. Policing: $A n$ International Journal of Police Strategies \& Management, 31(1), 129-147.

Schaufeli, W. B., Bakker, A. B., \& Van Rhenen, W. 2009. How changes in job demands and resources predict burnout, work engagement, and sickness absenteeism. Journal of Organizational Behavior, 30, 893-917.

Stormer, S., \& Fahr, R. 2013. Individual determinants of work attendance: evidence on the role of personality. Applied Economics, 45, 2863-2875.

Taylor, P., Cunningham, I., Newsome, K., \& Scholarios, D. 2010. The political economy of work and employment 'Too scared to go sick'-reformulating the research agenda on sickness absence. Industrial Relations Journal, 41(4), 270-288.

Taylor, S. E., \& Brown, J. D. 1988. Illusion and wellbeing: A social psychological perceptive on mental health. Psychological Bulletin, 103, 193-210.

Templer, K. J. 2012. Five-Factor Model of Personality and Job Satisfaction: The Importance of Agreeableness in a Tight and Collectivistic Asian Society. Applied Psychology, 61(1), 114-129.

Valentine, S., Greller, M. M., \& Richtermeyer, S. B. 2006. Employee job response as a function of ethical context and perceived organization support. Journal of Business Research, 59, 582-588.

Vearing, A., \& Mak, A. S. 2007. Big five personality and effort-reward imbalance factors in employees' depressive symptoms. Personality and Individual Differences, 43(7), 1744- 1755.

Vlasveld, M. C., van der Feltz-Cornelis, C. M., Anema, J. R., van Mechelen, W., Beekman, A. T., van Marwijk, H. W., \& Penninx, B. W. (2013). The associations between personality characteristics and absenteeism: A cross-sectional study in workers with and without depressive and anxiety disorders. Journal of Occupational Rehabilitation, 23(3), 309-317.

Walumbwa, F. O., \& Schaubroeck, J. 2009. Leader personality traits and employee voice behavior: mediating roles of ethical leadership and work group psychological safety. Journal of Applied Psychology, 94(5), 1275.

Wayne, J. H., Musisca, N., \& Fleeson, W. 2004. Considering the role of personality in the workfamily experience: Relationships of the big five to work-family conflict and facilitation. Journal of vocational behavior, 64(1), 108-130.

Williamson, J. M., Pemberton, A. E., \& Lounsbury, J. W. 2008. Personality traits of individuals in different specialties of librarianship. Journal of Documentation, 64(2), 273-286. 
Wright, M. E. 1997. Long-term sickness absence in an NHS teaching hospital. Occupational Medicine, 47(7), 401-406.

Xu, X., Yu, F., \& Shi, J. 2011. Ethical Leadership and Leaders' Personalities. Social Behavior \& Personality: An International Journal, 39(3), 361-368.

Zhao, H., \& Seibert, S. E. 2006. The big five personality dimensions and entrepreneurial status: a metaanalytical review. Journal of Applied Psychology, 91(2), 259.

Zimmerman, R. D. 2008. Understanding the impact of personality traits on individuals' turnover decisions: A meta-analytic path model. Personnel Psychology, 61, 309-348. 


\title{
PROCEDURAL JUSTICE, ENVY AND ORGANIZATIONAL CITIZENSHIP BEHAVIOR: A STUDY OF HEALTH PROFESSIONALS IN PAKISTAN
}

\author{
AYESHA NOOR \\ SAJID BASHIR \\ Mohammad Ali Jinnah University, Islamabad, Pakistan
}

\begin{abstract}
This study examines the impact of procedural justice on two dimensions of Organizational Citizenship Behavior (OCB) viz. Organizational Citizenship Behavior Individual (OCBI) and Organizational Citizenship Behavior Organization (OCBO) with mediating role of workplace envy among health professionals in Pakistan. The data was collected from 110 health professionals through questionnaires. Results indicate that though procedural justice is significantly associated with both dimensions of organizational citizenship behavior, the mediation of workplace envy is not established in case of relationship between procedural justice and OCBI. Implications that can help hospitals of Pakistan in augmenting the OCB are also discussed.
\end{abstract}

\section{INTRODUCTION}

A plethora of research during past few decades focused organizational citizenship behavior (OCB) (Cohen \& Kol, 2004), since it helps organization to enhance effectiveness, productivity, efficiency, profitability and customer satisfaction (Podsakoff. N, Whiting \& Podsakoff. P, 2009). OCB encourages an employee to work harder and contribute towards organizational performance (Somech \& Zahavy, 2004; Dimitriades, 2007). Studies also focused those factors which negatively affect employee OCB, and one of the recent additions in those factors is workplace envy which has the tendency to reduce extra-role helping behaviors among employees (Kim \& Radosevich, 2007).

Envy is the unpleasant and painful emotion illustrated by resentment, hostility and feelings of inferiority that originate by knowing that another person or group of person enjoyed the desired attribute (Smith \& Kim, 2007), and this feeling lowers organizational outcomes including profitability (Goel \& Thakor, 2005) and OCB (Hui, Law \& Chen, 1999).

While procedural justice as perceived by the individuals in the organizations results in OCB (Masterson, Lewis, Goldman, \& Taylor, 2000), the absence of it, along with other factors, will create the feelings of envy (Murphy, Wayne, Liden \& Erdogan, 2003). The Affective Events Theory by Weiss and Cropanzano (1996) provides sufficient theoretical underpinning to argue that in case procedural justice is not prevailing in the organizations, it will generate envy among employees which ultimately will reduce the OCB. However, this specific relationship has not been analyzed in extant literature.

This study will attempt to fill this literature gap by focusing specifically on the health professionals in Pakistan. Earlier studies suggest that though OCB has been extensively researched, yet little is known about its specific implications in health care sector (Farh, Zhong \& Organ, 2004). Moreover, studies also suggest that OCB shows a discrepancy among various cultures (Euwema, Wendt \& Emmerik, 2007), and the study of OCB in the Asian context will liberate the number of differences in the concepts as compared to European countries because of the cultural differences (Mohammad, Habib \& Zakaria, 2010). So, an added offshoot of this study is examination of the phenomenon in an Asian context.

\section{REVIEW OF LITERATURE}

\section{Procedural Justice and Organizational Citizenship Behavior}

When the authority takes decisions on the grounds of fair procedures, it is known as procedural justice (Lind \& Tyler, 1988). Procedural justice is considered to be the first step toward elevating the lawfulness in the environment (Sunshine \& Tyler, 2003). For showing dedication towards the acceptance of law, procedural justification is a mandate (Hough, Jackson, Bradford, Myhill \& Quinton, 2010). If the authority makes an impression of the fairness in procedural justice, it will 
help them to have enduring relationship with their employees because the employees will construct an opinion that the organization will always act justifiably (O’Hear, 2008).

Employees develop a positive perception about procedural justice if they find that higher authorities are making decisions accurately, and exhibiting fairness in their procedures (Bottoms \& Tankebe, 2012). If the policies exhibit justice, there will be enhancement in the quality of the relationships, which will ultimately reduce conflicts and augment the satisfaction level (Griffith, Harvey \& Lusch, 2006). Procedural justice is linked with intrinsic motivation level of an employee that will envisage the task performance of that employee in the organization (Zapata- Phelan, Colquitt, Scott \& Livingston, 2009). The mindset of the employees can also be modified if they are assured of the procedural justice in the organization. Greater the awareness of procedural justice, better are the behavioral outcomes (Workman, 2009). William and Anderson (1991) formed the two categories of OCB; first, that is beneficial for other individuals because of supporting, cooperating and helping behavior that is exhibited by the employee during work, was termed as OCBI, and second, behavior that benefits the organization because of the participation in implications for organizational development, was termed as OCBO. Organizational justice is related with the dimensions of OCB, i.e., OCBI and OCBO (Aryee \& Chay, 2001). An employee's OCBI is beneficial for the coworkers while OCBO is beneficial for the supervisors (LePine, Erez \& Johnson, 2002).

Pare and Tremblay (2007) found out through their studies that when employees sense that organization is executing their procedures justly, they become psychologically connected to the organization that blooms out the OCB in their actions. The focus on procedural justice is due to its impact on the OCB; it is not only to say that the organization is implying justice, it should be guaranteed to the employees that organization is functioning on the basis of fairness, as making employees conscious about procedural justice enhance their OCB (Blader \& Tyler, 2009). Fairness of procedures enhances their OCB (De Cremer \& Knippenberg, 2002).

\section{Hypothesis 1. Procedural justice has a significant and a positive relationship with the OCBI. Hypothesis 2. Procedural justice has a significant and a positive relationship with the OCBO.}

\section{Procedural Justice and Workplace Envy}

If organizations take care of the execution of the legitimacy in the procedures, then employees will feel that they are being considered important by the organization, otherwise they will judge organization as an entity that have no concern for its employees (Posthuma, Maertz, \& Dworkin, 2007). When the employees perceive injustice in the procedures of the organization, their trust level decreases which elicit negative events (Bal, deLange, Ybema, Jansen \& van derVelde, 2011), and workplace envy is one of the negative event. Hence we can argue that procedural injustice can cause envy.

\section{Hypothesis 3. Procedural justice has a significant and a negative relationship with workplace envy.}

\section{Workplace Envy and Organizational Citizenship Behavior}

Envy is characterized as a negative emotion (Stein, 1997), and it varies across cultures (Beckman, Formby, Smith \& Zheng, 2002). Envy is the evaluation of outcomes resulted by comparison (Herreiner \& Puppe, 2009). People have a tendency to be envious by referring to the others' benefits (Shamay-Tsoory et al., 2009). The social comparisons result in the negative behaviors such as envy (Takahashi et al., 2009). Envy will lead to the behaviors that are against the law (Gino \& Pierce, 2010). Envy is also generated on the good luck of other people (ShamayTsoory, Tibi-Elhanany \& Aharon-Peretz, 2007).

People are humane to others who are in their judgment, at lower level, and envious to the people who are at a higher level comparatively (Fehr, Ernst \& Schmidt, 1999). Envy is such a behavior that occurs frequently and repeatedly (Ven, Zeelenberg \& Pieters, 2011b). Individual, at first, forms a group who share common interests, and in the next step envy arises if the individual perceive that the other members of the group are performing well as compared to themselves (Goel \& Thakor, 2005). Envy has no aptness with individual well-being (Silver \& Sabini, 1978). The person who is envious become irritated and discouraged which are self-damaging behaviors, and is not able to alter or make the situation better (Ven, Zeelenberg \& Pieters, 2011a). Envy can be minimized if each individual focus on their own benefits (Hartline \& Yan, 2011).

By applying the attribution theory in the perspective of envy, it can be seen that the person who is experiencing the emotion of envy become dissatisfied by identifying the benefits enjoyed by the other person that he was hoping to have, thus will create inferiority complex and lower self-esteem (Salovey, 1991). Hence, when the employees are faced with organizational injustice, they will develop an emotion of hatred and anger (Skarlicki \& Folger, 1997) leading to envy that will result in employee dissatisfaction, turnover, aroused feeling of 
revenge, decreased OCB (Dogan \& Vecchio,2001).

Hypothesis 4. Workplace envy has a significant and a negative relationship with the OCBI.

Hypothesis 5. Workplace envy has a significant and a negative relationship with the OCBO.

\section{Mediating Role of Workplace Envy}

The emotion of envy is indexed with injustice (Ferguson, 2002). Injustice is the perception of the employee when they are not experiencing equality (Ambrose, Seabright \& Schminke, 2002). A number of authors studied the relationship between procedural injustices and envy (Cohen-Charash \& Byrne, 2008). The employee negative behavior arises when they are unjustly treated by the organization (O'Leary-Kelly, Grin \& Glew, 1996). Employee's belief of injustice is associated with his/her violent behavior (Greenberg \& Barling, 1999).

Envy leads to violent and rude behaviors (Khan, Peretti \& Quratulain, 2009). The social exchange theory by Gouldner (1960) depicts that employees confer their efforts and assistance to the organization with anticipation that the organization will grant them the equivalent level of privileges, and if this exchange is perceived as procedurally illegitimate then this standard in the minds of the employee will be debilitated. When the employees see that the organization is treating them unfairly and unjustly in the execution of procedures, distribution and interaction, it will bring employees to the point where they would want to take revenge from the organization by deliberating and executing the negative outcomes (Skarlicki \& Folger, 1997) and declining the level of OCB (Lavelle, Rupp, \& Brockner, 2007).

Hypothesis 6. Workplace envy mediates the relationship between procedural justice and $O C B I$.

Hypothesis 7. Workplace envy mediates the relationship between procedural justice and $O C B O$.

\section{METHODOLOGY}

\section{Measuring Instrument}

A 32-items questionnaire was used. Procedural Justice was measured using six items, a scale developed by Niehoff and Moorman (1993). Workplace Envy was measured through a five items scale adopted from Vecchio (2000), while Organizational Citizenship Behavior was measured using fourteen items scale developed by Williams and Anderson (1991). A five point Likert scale was used to measure respondent's possible responses ranging from $1=$ strongly disagree to $5=$ strongly agree. The reliability test was done that showed cronbach's alpha value of .800 for Procedural justice scale, 0.78 for workplace envy scale and 0.81 for organizational citizenship behavior scale, which showed the questionnaire used is reliable.

\section{Sample Characteristics}

Results were collected from medical doctors. Among these doctors $30 \%$ were employed for less than 1 year, $10 \%$ were employed from 1 year to 2 years, $10.9 \%$ were employed from 2 years to 3 years and $49.1 \%$ were employed for more than 3 years. $30.9 \%$ of employees were holding MBBS degree, $21.8 \%$ of employees were holding the BDS degree and $47.3 \%$ had other specialization degrees. Among respondents, $69.1 \%$ were married and $30.9 \%$ were unmarried. Majority of respondents $60.9 \%$ were males and females represented $39.1 \%$.

TABLE 1

Correlation Analysis

\begin{tabular}{|c|c|c|c|c|c|c|c|c|c|}
\hline & 1 & 2 & 3 & 4 & 5 & 6 & 7 & 8 & 9 \\
\hline 1.Employed & 1 & & & & & & & & \\
\hline 2.Qualification & 0.006 & 1 & & & & & & & \\
\hline 3. Status & $-.876^{* *}$ & 0.236 & 1 & & & & & & \\
\hline 4. Gender & $-.775^{* *}$ & 0.299 & $.835^{*}$ & 1 & & & & & \\
\hline 5. Age & $.709 * *$ & -0.266 & $-.660^{*}$ & $-.584 *$ & 1 & & & & \\
\hline 6. Procedural justice & $.461^{*}$ & $-.330 * *$ & $-.332 *$ & $-.573 *$ & $.565^{*}$ & 1 & & & \\
\hline 7.Workplace Envy & $.466^{*}$ & $.596^{*}$ & $-.340^{*}$ & $-.247 *$ & $.333^{*}$ & $-.226^{*}$ & 1 & & \\
\hline 8. Organizational citizenship behavior Individual & $.497^{*}$ & $.189^{*}$ & $-.301 *$ & $-.345^{* *}$ & 0.169 & $.229^{*}$ & $-.530^{*}$ & 1 & \\
\hline 9. Organizational citizenship behavior organization & $.682 *$ & $-.495^{*}$ & $-.614 * *$ & $-.618^{*}$ & $.812 * *$ & $.777 * *$ & $-.322 *$ & 0.151 & 1 \\
\hline
\end{tabular}


The above table is showing the correlation values between the independent, mediating and dependent variables. The correlation values between OCBI and procedural justice is .229*, showing Procedural Justice to have a positive relationship with OCBI . Workplace envy has the value of $-.530^{*}$ with OCBI which shows that workplace envy is negatively associated with OCBI. The correlation values between OCBO and procedural justice is $777 * *$ which depicts that procedural justice has positive association with the OCBO and the value of OCBO with workplace envy is $-.322 *$ showing that Workplace Envy is negatively associated with OCBO. The correlation value between workplace envy and procedural justice is $-.226^{*}$ which shows that procedural justice is negatively associated with workplace envy.

TABLE 2

Regression Analysis

\begin{tabular}{cccccccccc}
\hline \multicolumn{4}{l}{ WE (Workplace Envy) } & \multicolumn{3}{c}{ OCBI } & \multicolumn{3}{c}{ OCBO } \\
$\boldsymbol{\beta}$ & $\mathbf{R}^{2}$ & $\Delta \mathbf{R}^{2}$ & $\boldsymbol{\beta}$ & $\mathbf{R}^{2}$ & $\Delta \mathbf{R}^{2}$ & $\boldsymbol{\beta}$ & $\mathbf{R}^{2}$ & $\Delta \mathbf{R}^{2}$ \\
\hline
\end{tabular}

MEDIATION

Main effect:

Procedural justice

Step 1

Control Variables

.787

.388

.870

Step 2

PJ

$$
-.216^{* *} \quad .806 \quad .019^{* *} \quad .174^{*}
$$

$.049^{*}$

$.394 * * *$

.932

$.063^{* * *}$

\section{MEDIATION: WE}

\section{Step 1}

Control Variables

Step 2

WE

Step 3

PJ ${ }^{*} \leq \leq .05, \quad * * p \leq .01, * * * p \leq .001$

The regression analyses show that procedural justice has the beta value of $-.216^{* *}$ at $p \leq 0.01$ with workplace envy, explaining that procedural justice has the significant negative relationship with the workplace envy. The beta value between procedural justice and OCBI is .174* at $\mathrm{p} \leq 0.05$ showing that procedural justice has the significant positive relationship with OCBI. The beta value between procedural justice and OCBO is .394*** illustrating that procedural justice has the significant positive relationship with OCBO. The beta values of OCBI and OCBO with workplace envy are $-.879 * * *$ and $-.230 * * *$ depicted that workplace envy has the significant negative relationship with the OCBI and OCBO. The mediation result shows that workplace envy mediates between the relationship of PJ and OCBO but does not mediate between the relationship of procedural justice and OCBI. So according to the results of hypotheses $\mathrm{H}_{1}, \mathrm{H}_{2}, \mathrm{H}_{3}, \mathrm{H}_{4}, \mathrm{H}_{5}$ and $\mathrm{H}_{7}$ are accepted whereas $\mathrm{H}_{6}$ is rejected.

\section{CONCLUSION \& DISCUSSION}

The main objective of this study was to analyze what role procedural justice plays in determining OCB, and whether workplace envy mediates the relationship among the health professionals. The results show that procedural justice is positively linked with the OCBI and OCBO meaning that fairness in the procedures boosts OCB. The result also depicts that when justice is prevailing in the organization, envy will decrease and if procedural justice is not present then it arises the negative feeling, i.e. envy, which will lead to the negative outcomes. Procedural injustice refers to the unfairness in the procedures making the employee negative towards the organization and it will create envy in them. When employees see that the higher authority is treating them unjustly, then the employees will go pessimistic about the organization that will enhance envy at workplace.

The results reveal that workplace envy will mediate 
the relationship between the procedural justice and OCBO. So it shows that procedural justice helps in reducing the workplace envy that results in the increase of organizational citizenship behavior(Organizational). The research conducted by Moorman, Blakely and Niehoff (1998) shows that OCB is affected by the procedural justice because justice in procedures foster the support of the organization for their employees and also when relationships are maintained on the basis of justice, then that fair collaboration will direct the employee OCB (Cropanzano, Rupp, Mohler \& Schminke, 2001).

This study indicates that health professionals in Pakistan consider procedural justice important for having OCB. Their nature of job is quite delicate and OCB can ultimately result in higher levels of patient satisfaction. Hence the organizations employing health professionals should foster such an environment where justice is visible in form of equitable rewards and opportunities for them. Since procedural justice is negatively associated with workplace envy, its opposite is equally true. Organizations having procedural injustice favor some employees which can cause envious behaviors in others. However, the mediating role of envy at organizational level indicates that health professionals' organizational level citizenship behavior is affect more by procedural justice mediated by workplace envy. The possible explanation can be linked to the affect that when employees feel that organizations lack integrity, it can result in a host of outcomes including a reduction in organizational commitment and organizational level citizenship behavior.

These findings provide basic guidelines for health sector organizations operating in Pakistan. If they really want to have dedicated professionals in their organizations, they will have to take initiative by promoting an environment where justice can be seen by everyone, which in turn will reduce envy, and employees will show citizenship behavior towards the organization.

\section{REFERENCES}

Ambrose, M. L., Seabright, M. A., \& chminke, M. 2002. Sabotage in the workplace: The role of organizational injustice. Organizational Behavior and Human Decision Processes, 89, 947-965.

Aryee, S., \& Chay,Y. W. 2001.Workplace justice, citizenship behavior and turnover intentions in a union context: Examining the mediating role of perceived union support and union instrumentality. Journal of Applied Psychology, 86(1), 154-160.

Bal, P. M., deLange, A. H., Ybema, J. F., Jansen, P. G. W., \& Van der Velde, M. E. G. 2011. Age and Trust as Moderators in the Relation between Procedural
Justice and Turnover: A Large-Scale Longitudinal Study. Applied Psychology, 60 (1), 66-86

Beckman, S. R., Formby, J. P., Smith,W. J., \& Zheng, B. 2002. Envy, malice and Pareto efficiency: An experimental examination. Social Choice and Welfare, 19(2), 349-367.

Blader, S. L., \& Tyler, T. R. 2009. Testing and Extending the Group Engagement Model: Linkages Between Social Identity, Procedural Justice, Economic Outcomes and Extra role Behavior. Journal of Applied Psychology, 94(2), 445-464.

Bottoms, A., \& Tankebe, J. 2012. Criminology beyond procedural justice:Adialogic approach to legitimacy in criminal justice. The journal of criminal law \& criminology, 102(1).

Cohen, A., \& Kol. Y. 2004. Professionalism and organizational citizenship behavior; an empirical examination among Israeli nurses. Journal of Managerial Psychology, 19 (4), 386-405.

Cohen-Charash, Y., Byrne, Z. S. 2008. Affect and justice: current knowledge and future directions. In N. M. Ashkanasy\& C. L. Cooper (Eds.) Research companion to emotion in organizations, Edward Elgar Publishers, 360-391.

Cropanzano, R., Rupp, D. E., Mohler, C. J., \& Schminke, M. 2001. Three roads to organizational justice. Research in personnel and human resources management, 20, 1-113.

De Cremer, D., \& Knippenberg, D. 2002. How do leaders promote cooperation? The effects of charisma and procedural fairness. Journal of Applied Psychology, 87, 858-866.

Dimitriades, Z. S. 2007. The influence of service climate and job involvement on customer-oriented organizational citizenship behavior in Greek service organizations: a survey. Employee Relations, 29 (5), 469-491.

Dogan. K., \& Vecchio, R. P. 2001. Managing Envy and Jealousy in the Workplace. Compensation Benefits Review, 33(2), 57-64.

Dyne, L.V., Kossek, E., \& Lobel, S. 2007. Less need to be there: Cross-level effects of work practices that support work-life flexibility and enhance group processes and group-level OCB. Human Relations, 60(8), 1123-1154.

Euwema, M. C., Wendt, H., \& Emmerik, H. V. 2007. Leadership styles and group organizational citizenship behavior across cultures. Journal of Organizational Behavior. DOI: 10.1002/job.496

Farh, J. L., Zhong, C. B., \& Organ, D. W. 2004. Organizational Citizenship Behavior in the People's Republic of China. Organization Science, 15(2), 241-253.

Fehr, Ernst, \& Schmidt, K. M. 1999.A Theory of Fairness, 
Competition, and Cooperation. The Quarterly Journal of Economics, 114,817-868.

Ferguson, F. 2002. Envy Rising.ELH, 69(4), 889-905.

Gino, F., \& Pierce, L. 2010. Robin Hood under the Hood: Wealth-Based Discrimination in Illicit Customer Help. Organization Science, 21(6), 1176-1194.

Goel, A. M., \& Thakor, A. V. 2005. Green with Envy: Implications for Corporate Investment Distortions. The Journal of Business, 78(6), 2255-2288.

Gonza'lez, J. V., \& Garazo, T. G. 2006. Structural relationships between organizational service orientation, contact employee job satisfaction and citizenship behavior. International Journal of Service Industry Management, 17(1), 23-50.

Gouldner, A.W. 1960. The norm of reciprocity: A preliminary statement. American Sociological Review, 25, 161-178.

Greenberg. L., \& Barling, J. 1999. Predicting employee aggression against coworkers, subordinates and supervisors: the roles of person behaviors and perceived workplace factors. Journal of Organizational Behavior, 20, 897-913.

Griffith, D. A., Harvey, M. G., \& Lusch, R. F. 2006. Social exchange in supply chain relationships: The resulting benefits of procedural and distributive justice. Journal of Operations Management (24) 85-98.

Hartline, J. D., \& Yan, Q. 2011. Envy, Truth, and Profit. Proceedings of the ACM Conference on Electronic Commerce, 243-252.

Herreiner, D. K., \& Puppe, C. 2009. Envy Freeness in Experimental Fair Division Problems. Theory and Decision, 67(1), 65-100.

Hough, M., Jackson, J., Bradford, B., Myhill, A., \& Quinton, P. 2010. Procedural Justice, Trust, and Institutional Legitimacy. A journal of policy and practice, 4(3), 203-210.

Hui, C., Law, K. S., \& Chen, Z. X. 1999.A Structural Equation Model of the Effects of Negative Affectivity, Leader-Member Exchange, and Perceived Job Mobility on In-Role and Extra-Role Performance: A Chinese Case. Organizational Behavior and Human Decision Processes, 77(1), 3-21.

Khan, A. D., Peretti. J. M., \& Quratulain, S. 2009. Envy and counterproductive behaviors: Is more fairness always preferred? 20th AGRH Conference of the French-speaking HR/OB Research Scholarly Association.

Kim, S. K., \& Radosevich, D. J. 2007. The impact of workplace envy on organizational citizenship behavior with leader-member exchange in the service industry. International Academy of Business and Economics ,7(3).
Lavelle, J. J., Rupp, D. E., \& Brockner, J. 2007. Taking a multifoci approach to the study of justice, social exchange, and citizenship behavior: The target similarity model. Journal of Management, 33, 841-866.

LePine, J. A., Erez, A., \& Johnson, D. E. 2002. The Nature and Dimensionality of Organizational Citizenship Behavior: A Critical Review and MetaAnalysis. Journal of Applied Psychology, 87(1), $52-65$.

Lind, E. A., \& Tyler, T. R. 1988. The social psychology of procedural justice. New York: Plenum.

Masterson, S.S., Lewis, K., Goldman, B.M. \& Taylor, M.S. 2000. Integrating justice and social exchange: The differing effects of fair procedures and treatment on work relationships. Academy of Management Journal, 2000, 43, 738-48.

Mohammad, J., Habib, F. Q., \& Zakaria, S. 2010. Organizational citizenship behavior and commitment: Do age and tenure make any difference? Business management quarterly review, 1(3).

Moorman, R. H., Blakely, G. L., \& Niehoff, B. P. 1998. Does perceived organizational support mediate the relationship between procedural justice and organizational citizenship behavior?. Academy of Management journal, 41(3), 351-357.

Murphy, S. M.,Wayne, S. J., Liden, R. C., \& Erdogan, B. 2003. Understanding social loafing: The role of justice perceptions and exchange relationships. Human Relations, 56(1), 61-84.

Niehoff, B. P. \& Moorman, R. H. 1993. Justice as a mediator of the relationship between methods of monitoring and organizational citizenship behavior. Academy of Management Journal, 36,527-556.

O'Hear, M. M. 2008. Plea Bargaining and Procedural Justice. Georgia Law Review, 42(407).

O'Leary-Kelly, A. M., Grin, R. W., \& Glew, D. J. 1996. Organization-motivated aggression: A research framework. Academy of Management Review, 21, 225,253 .

Paré,G., \& Tremblay, M. 2007. Procedural Justice, Organizational Commitment, and Citizenship BehaviorsonInformationTechnologyProfessionals' Turnover Intentions. Group \& Organization Management, 32(3), 326-357.

Podsakoff, N. P., Whiting. S. W., \& Podsakoff. P. M. 2009. Individual- and Organizational Level Consequences of Organizational Citizenship Behaviors: A Meta-Analysis. Journal of Applied Psychology, 94(1), 122-141.

Posthuma, R. A., Maertz, C. P. Jr., \& Dworkin, J. B. 2007. Procedural justice's relationship with turnover: Explaining past inconsistent findings. Journal of 
Organizational Behavior, 28, 381-398.

Salovey, P. 1991. Social comparison processes in envy and jealousy. In J. Suls \& T. A. Wills (Eds.), Social comparison: Contemporary theory and research, Hillsdale, NJ : Erlbaum, 261-285.

Shamay-Tsoory, S. G., Fischer, M., Dvash, J. Harari, H., Perach-Bloom, N., \& Levkovitz, Y. 2009. Intranasal Administration of Oxytocin Increases Envy and Schadenfreude (Gloating). Society of Biological Psychiatry. www.sobp.org/journal

Shamay-Tsoory, S. G., Tibi-Elhanany, Y. \& AharonPeretz, J. 2007. The green-eyed monster and malicious joy: the neuroanatomical bases of envy and gloating (schadenfreude). Brain, 130, 16631678.

Silver, M., \& Sabini, J. 1978. The Perception of Envy. Social Psychology, 41(2), 105-117.

Skarlicki, D., \& Folger, R. 1997. Retaliation in the Workplace: The Roles of Distributive, Procedural, and Interactional Justice. Journal of Applied Psychology, 82(3), 434-443.

Smith, R. H., \& Kim, S. H. 2007. Comprehending Envy. Psychological Bulletin Copyright, 133(1), 46-64.

Somech, A, \& Zahavy, A. D. 2004. Exploring organizational citizenship behavior from an organizational perspective: The relationship between organizational learning and organizational citizenship behavior. Journal of occupational and organizational psychology, 77,281-298.

Stein, M. 1997. Envy and leadership. European Journal of Work and Organizational Psychology, 6(4), 453-465.

Sunshine, J. \& Tyler, T. R. 2003. The Role of Procedural Justice and Legitimacyin Shaping Public Support for Policing. Law \& Society Review, 37(3).

Takahashi, H., Kato, M., Matsuura, M., Mobbs, D., Suhara, T., \& Okubo, Y. 2009. When Your Gain Is My Pain and Your Pain Is My Gain: Neural Correlates of Envy and Schadenfreude. SCIENCE, 323.

Vecchio, R. P. 2000. Negative emotion in the workplace: Employee jealousy and envy. International Journal of Stress Management, 7,161-179.

Ven, N. D., Zeelenberg, M., \& Pieters, R. 2011b. The Envy Premium in Product Evaluation. The Journal of Consumer Research, 37(6), 984-998.

Ven, N. V. D., Zeelenberg, M., \& ieters, R. 2011a. Why Envy Out performs Admiration. Personality and Social Psychology Bulletin, 37(6) 784-795.

Weiss, H. M., \& Cropanzano, R. 1996. Affective Events Theory: A Theoretical Discussion of the Structure, Causes and Consequences of Affective Experiences at Work. Research in Organizational Behavior, 19, $1-74$.

Williams, L. J. \& Anderson, S. E. 1991. Job satisfaction and organizational commitment as predictors of organizational citizenship and in-role behaviours. Journal of Management 17,601-617.

Workman, M. 2009.A field study of corporate employee monitoring: Attitudes, absenteeism, and the moderating influences of procedural justice perceptions. Information and Organization. doi:10.1016/j.infoandorg.

Zapata-Phelan, C. P., Colquitt, J. A., Scott B. A., \& Livingston, B. 2009. Procedural justice, interactional justice, and task performance: The mediating role of intrinsic motivation. Organizational Behavior and Human Decision Processes 108, 93-105. 


\title{
THE IMPACT OF LOCUS OF CONTROL ON TRAINING TRANSFER WITH MEDIATING ROLE OF JOB SATISFACTION AND ACHIEVEMENT MOTIVATION
}

\author{
SYEDA MEHVISH ALI \\ Mohammad Ali Jinnah University, Islamabad, Pakistan
}

\begin{abstract}
The core objective of this study is to explore the relationship between locus of control and Training Transfer in the telecom industry of Pakistan. This relationship was studied under the influence of two other variables acting in mediation role i.e. achievement motivation and Job satisfaction. The sample consists of 200 employees from telecom sector. Results indicate significant relationship between locus of control, training transfer and achievement motivation while job satisfaction plays a vital role in the mediation process.
\end{abstract}

\section{INTRODUCTION}

Locus of Control (LOC) gained immense importance in the Organizational Psychology as it is considered as a dispositional factor which determines the perception of an employee; developed through learned behaviour and then reinforcement of the behavior at work (Salazar \& Pfaffenberg, 2006). However, there is a mixed response in literature as far as LOC and transfer of training are concerned. Colquitt et al. (2000) found an inverse relation with the transfer of training and Locus of Control. According to their study, people with External Locus of Control learn more and have level of transfer of training. However, Wilson, Strutton, and Farris (2002) conducted a study on different perceptual aspects of sales training and found that sales person with external locus of control were dissatisfied with the training as they were expecting more from it than the training could actually deliver. Hence, the chances of training transfer are low in such individuals. There is a need to further clarify this link between LOC and transfer of training (Burke \& Hutchins, 2007), which is precisely the reason for conducting this study.

Recently, achievement motivation along with professional training was studied to determine the factors that influence (or not influence) the employees to continue their job trainings. Their findings indicated that the desire to learn through trainings has a strong link with achievement motivation since the employee will lose motivation to learn if it is not improving his/ her job in terms of promotion. With such latest finding, it will be interesting to know the role of achievement motivation as mediator with reference to locus of control and training transfer in Pakistani context.

Job satisfaction due to its dispositional nature has a strong link with Locus of control and it has been studied in various studies as dependent variable. Mahajan \& Kaur (2012) studied the relationship between Locus of control and Job satisfaction among College teachers and found positive association between the two variables. Carr (2011), also found that happiness, extroversion and optimism were the qualities associated with the individuals termed as "Internals" Locus of Control, whereas neuroticism and unhappiness were the qualities associated with individuals termed as "External" Locus of control in the prevailing western culture which proves a very strong link with employee satisfaction. Therefore Job Satisfaction becomes an important mediator in our context.

In the context of Pakistan, there is hardly any work done with reference to LOC. A study was conducted to examine the affects of External LOC on Organizational Commitment among the University Professors in Pakistan, which finds a significant relation between the two variables (Munir \& Sajid, 2010). We will be focusing on the Telecom Sector of Pakistan as it is one the fastest growing sectors with highly competitive business market and cut throat competition. Pakistan being one of the developing nations is rich in emotional attitudes by virtue of its collectivist culture in relation to the influence of the past experience on future outcomes (Shahzad et. al, 2011). Our present study will further extend the body of knowledge of LOC in Telecom Sector of Pakistan. 


\section{THEORETICAL BACKGROUND AND HYPOTHESES}

\section{Locus of Control}

According to Bandura (1977) little attention has been given to one of the most important factor in human behavior i.e. Self-Regulatory Behaviors. These Self-Regulatory behaviors can be controlled by a conscious effort of the individual thus resulting in the conscious decision making process (Baumeister, 2008). These conscious decision makers were termed as Internals (by Julian Rotter in his theory of Locus of Control) who believed to be in control of their destinies and Externals for those people who believed in luck/ bad luck and powerful others determining their fate (Twenge, Zhang \& Im, 2004).

The research further establishes and supports the importance by the fact that the internals carry a positive attitude both at work and in their everyday life (Spector et al., 2002). Such Individuals are more likely to meet challenges and will be successful in achieving their goals and objectives (Mahajun \& Kaur, 2012), whereas the externals involve themselves in escape mechanism, and avoids dealing with the problem (Cavaiola \& DeSordi, 2000).

The association of Locus of control with the well-being of the individual has significant impact on personal well-being of the individual along with the job related affective reactions (Wrightson \& Wardle, 1997; Kirkcaldy et al. 2007; Hans, Mubeen, \& Ghabshi, 2013). The personal well-being includes mental wellbeing, life satisfaction and physical health whereas affective reactions are reflected in job satisfaction, pay, promotions, affective commitment and turnover $(\mathrm{Ng}$, Sorensen \& Eby, 2006). It is argued that the individuals with internal locus of control are psychologically healthier due to their belief that external factors are under their control. This mere belief that one can exert control is intrinsically satisfying (Ganster \& Fusilier, 1989). In the organization when employee believe that they can govern and create their own environment by controlling the external factors, they feel empowered and utilize their abilities to their best level, thus enhancing their learning ability to manifold (Spreitzer, 1996).

\section{Locus of control and Training Transfer}

The term "Transfer" was the term coined by Baldwin and Ford (1988), which they defined as the degree to which participants are able to apply the knowledge, skills, and attitudes acquired during an occupational training. The Training Process involves learning set of new knowledge, skills and attitude in one environment (Training situation) and then its actual implementation on the work environment (Goldstein \& Ford, 2002). The successful training implies that what learnt during the training is applied on the work, therefore improving the work quality of an employee. However, it is estimated that only $10 \%$ of the training is applied by the trainee at work.

Formal employee training typically involves learning new knowledge, skills, attitudes or other characteristics in one environment(thetraining situation) that can be applied or used in another environment (the performance situation). Presumably, what was learned in training should be applied to performance on the job. However, a common experience is that learning from a formal training program is not carried back for application on the job (Arthur et.al., 2003). The studies showed that loss of skills was $87 \%$ of the trainees within the first month of the training completed (Noe, 1986).

Some studies found out that the attribution (External or Internal) has a very significant role in enhancing the learning ability of the trainees. They argued that if the trainee is motivated and believe that he/she can deliver, then the training process will be facilitated. Low transfer of training is mainly the result of employees' low belief on their abilities and high belief in the external factors. Colquitt et.al (2000), Balwin \& Ford (1988); Cavaiola \& Desordi (2000); Spreitzer (1996). The selfbelief in ones abilities was termed as Internals whereas reliance on external factors was termed as Externals by Rotter (1966). Therefore we formulate the following hypothesis

\section{Hypothesis 1. External locus of control has significant negative relation with training transfer}

\section{Locus of Control and Job Satisfaction}

According to Locke (1976), "Job satisfaction may be defined (for the present) as a pleasurable or positive emotional state resulting from the appraisal of one's job or job experience". According to Calvo-Salguero (2010), job satisfaction is the attitude associated with the degree to which people like or dislike their jobs leading to the level of job satisfaction of the employee. They argue that the low level of job satisfaction is associated with negative behavior at work which results in absenteeism, turnover and reduced productivity. Job satisfaction can be measured from two factors: Job characterization and the disposition of the employee (Grandey et al., 2005). One measures the nature of the job and other is used to access the attitude of the 
employee to carry out his/her job which constitutes the job satisfaction. They also argued that when a situation threatens our self-identity, the employee shows negative response to that perceived threat and therefore develops a negative attitude towards it. Such negative behavior towards the perceived threat contributes in low level of job satisfaction.

Research indicates that Job satisfaction is associated with internal locus of control whereas job dissatisfaction is linked with external locus of control (Carrim, Basson \& Coetzee, 2006). The individuals who are internally focused relate their achievements at their workplace by controlling the external factors whereas externally focused individuals feel that external factors are not in their control thus resulting in dissatisfaction and negative attitude towards work. Hans et al (2013) studied the relationship between Locus of Control and Job Satisfaction in semi government organization operating in Oman. Their findings indicate that the employees with Internal Locus of Control were relatively satisfied than the employees with External Locus of Control. Therefore we hypothesize that

\section{Hypothesis 2. External Locus of control has significant Negative relation with Job Satisfaction}

\section{Locus of Control and Achievement Motivation}

Achievementmotivationis defined as anindividual's tendency to desire and work toward accomplishing challenging personal and professional goals (Byrne et al. 2004). According to Wigfield \& Eccles (2000), it refers to an individual's personality trait who has a strong desire for significant accomplishment, mastering of skills, control, or high standards characterized by an endurance and consistency. According McClelland (1987) this need is driven by an internal drive for action (intrinsic motivation), and also by the external factors like expectations of others (extrinsic motivation).

For Achievement motivation an individual has to plan and exercise control in order to fulfil the expectations from his organization, as such individuals with high achievement motivation will be able to see that future, depending on their abilities and not the external contingencies (Nicholls, 1984). This establishes a link between achievement motivation and locus of control (Phillips \& Gully, 1997). The individuals with internal locus of control will attribute their success and achievement to the consequence of their own behaviour. Hence following hypothesis is proposed

Hypothesis 3. External Locus of control has significant Negative relation with Achievement Motivation

\section{Job Satisfaction, Achievement Motivation and Training Transfer}

Learning abilities of the trainees depends on their level of motivation to learn. It has been a proved that the individuals with high level of job satisfaction will have high motivation level which will increase their ability to learn (Egan, Yang \& Bartlett, 2004). This eventually expedites the transfer of training process. According to Colquit, et al., (2000), the cognitive abilities of the trainees were reported to be enhanced due their increased level of job satisfaction and their desire to achieve more challenging goals. Hence we hypothesize that

\section{Hypothesis 4. Job Satisfaction has significant positive relation with Training Transfer \\ Hypothesis 5. Achievement Motivation has significant positive relation with Training Transfer}

\section{Mediating Role of Job Satisfaction \& Achievement Motivation}

According to Inozu, Yorulmaz, and Terzi (2012), Job satisfaction and achievement motivation are twoof the dispositional factors which determine the employees' attitude towards work. According to Ryon \& Gleason (2013), individuals who feel more in control of their own outcomes are more likely to be optimistic, engage in positive health behaviors, and are less prone to depression in the face of adversity. They further added that such healthy attitude is associated with high performance, job satisfaction and desire to achieve more. It is believed that training is a function of ability and motivation which they presented in a relation: Trainability $=\mathrm{f}$ (Ability + Motivation $)$. This aspect of training was further strengthened by Ford and Weissbein (1997) when they concluded that it will be reasonable to expect that personality factors might not only predict the future job performance but it will also have an impact on the individual's motivation to learn, learning strategies used during training, skill acquisition and training transfer. We therefore hypothesize that
Hypothesis 6. Job Satisfaction significantly mediates the relationship between External Locus of Control and Training Transfer
Hypothesis 7. Achievement Motivation significantly mediates the relationship between External Locus of Control and Training Transfer 


\section{METHODOLOGY}

\section{Data and Sample}

The data for this research was taken from Senior and Middle level management employees of Telenor situated in Islamabad, Pakistan, employing selfadministered study questionnaires. Questionnaires were passed on over to respondents together with a note that explained the intent behind the research in broad terms. The respondents were reassured that their responses will remain confidential for the sake of this study and their participation in this study is purely on volunteer basis.

Of the 300 questionnaires dispersed, 203 completed questionnaires were received back. Overall, the response rate was $67 \%$. After eliminating 3 unusable responses, 200 continued and constituted the sample for this analysis.

\section{MEASURES}

\section{Locus of Control}

The scale was developed by Suárez-Álvarez, et al.(2013), with reported coefficient alpha of 0.73 for measuring external Locus of Control. 11 Items were assessed on 5-point Likert scale. The scales had the anchor of $1=$ strongly disagree and $5=$ strongly agree. A sample item was "Landing a good job depends more on "string-pulling" than on training".

\section{Job Satisfaction}

A 6-item abbreviated version of an 18-item scale was used to measure job satisfaction. Coefficient alpha values for six item version ranged between 0.83 to 0.90 (Fields, 2003). Items were assessed on 5-point Likert scale, with anchor of $1=$ strongly disagree and $5=$ strongly agree. A sample item was "I am often bored with my job". The scale's alpha reliability in this study is 0.73 .

\section{Achievement Motivation}

The Scale was developed by Suárez-Álvarez, et al.(2013) with alpha reliability of 0.85. 9-item scale was used to measure Achievement Motivation. Items were assessed on 5-point Likert scale, with anchor of $1=$ strongly disagree and $5=$ strongly agree. A sample item was "I make an effort to be one of the best at work".

\section{Training Transfer}

The Training Transfer was measured using a 5-item scale with alpha reliability of 0.73 . Items were assessed on 5-point Likert scale, with anchor of $1=$ strongly disagree and $5=$ strongly agree. A sample item was "My organization considers training as a part of organization strategy". The alpha reliability of scale in this study is 0.71 .

\section{RESULTS}

Descriptive statistics as well as inter correlations among variables are discussed in table 1 .

TABLE 1

Descriptive Statistics and Correlation Analysis

\begin{tabular}{lcccccccccc}
\hline & Mean & SD & $\mathbf{1}$ & $\mathbf{2}$ & $\mathbf{3}$ & $\mathbf{4}$ & $\mathbf{5}$ & $\mathbf{6}$ & $\mathbf{7}$ & $\mathbf{8}$ \\
\hline Gender & 1.38 & 0.49 & - & & & & & & & \\
Age & 4.28 & 1.91 & 0.015 & & & & & & & \\
Category & 2.84 & 1.01 & 0.002 & -0.165 & & & & & & \\
Experience & 4.26 & 2.13 & -0.096 & 0.256 & -0.056 & & & & & \\
Loc of Control & 2.97 & 0.66 & -0.056 & -0.297 & 0.144 & -0.086 & -0.74 & & & \\
Job satisfaction & 3.11 & 0.67 & 0.184 & 0.226 & -0.017 & 0.016 & $-.745^{* *}$ & -0.47 & & \\
Achieve Motivation & 3.02 & 0.58 & 0.137 & 0.269 & 0.021 & 0.119 & $-.635^{* *}$ & $.659^{* *}$ & -0.58 & \\
Training transfer & 3 & 0.68 & 0.124 & 0.149 & -0.051 & 0.069 & $-.814^{* *}$ & $.815^{* *}$ & $.780^{* *}$ & -0.93 \\
\hline
\end{tabular}

Note. Cronbach's alpha reliabilities appear in parentheses, ${ }^{*} p<0.01$.

All the variables had acceptable Cronbash's alpha reliability. External locus of control was negatively related to training transfer $\left(\mathrm{R}^{2}=.68, \mathrm{P}<.01\right)$, however beta value is $-0.87,(\beta=-0.87, \mathrm{P}<.01)$ negative sign showing that there is negative relation between the variables. For every unit increase in external locus of control their will be .87 unit decrease in the training transfer. Higher beta value shows the presence of any mediating or moderating variable. Table 1 shows negative correlation of external locus of control with job satisfaction (-0.745), achievement motivation (-0.635) and training transfer $(-0.814)$.

Moreover table $2 \& 3$ shows direct relation of external locus of control with job satisfaction $(\beta=-0.75$, 
$\left.\mathrm{R}^{2}=0.58, \mathrm{P}<0.01\right)$ and achievement motivation $(\beta=$ $\left.-0.54, \mathrm{R}^{2}=0.44, \mathrm{P}<0.01\right)$ respectively. The above results supports our hypothesis which states that external locus of control is negatively related to Training Transfer $\left(\mathrm{H}_{1}\right)$, achievement motivation $\left(\mathrm{H}_{2}\right)$, and Job Satisfaction $\left(\mathrm{H}_{3}\right)$. Table 1 also shows that job satisfaction and achievement motivation is positively related to training transfer $(0 . .815 \& 0.78$ respectively), moreover table $2 \& 3$ reports the direct impact on training transfer of mediating variables i.e. job satisfaction $\left(\beta=0.84, \mathrm{R}^{2}=\right.$ $0.82, \mathrm{P}<0.01)$ and achievement motivation $\left(\beta=0.94, \mathrm{R}^{2}\right.$ $=0.62, \mathrm{P}<0.01)$ which supports our hypothesis $\mathrm{H} 4$ and $\mathrm{H} 5$ which states that job satisfaction and achievement motivation are positively related to training transfer.

Table 2 contains hierarchical regression analysis of external locus of control and training transfer with job satisfaction as mediator.

TABLE 2

Hierarchical Regression Analysis for External Locus of control and Training Transfer with Job satisfaction as a Mediator

\begin{tabular}{|c|c|c|c|}
\hline \multirow{2}{*}{$\begin{array}{c}\text { Variables } \\
\text { Direct Effect }\end{array}$} & \multicolumn{3}{|c|}{ Job Satisfaction } \\
\hline & $\beta$ & $\mathbf{R}^{2}$ & $\Delta \mathbf{R}^{2}$ \\
\hline Controls & & 0.09 & 0.003 \\
\hline \multirow[t]{3}{*}{ External LOC } & $-0.75 * *$ & 0.58 & 0.54 \\
\hline & \multicolumn{3}{|c|}{ Training Transfer } \\
\hline & $\beta$ & $\mathbf{R}^{2}$ & $\Delta \mathbf{R}^{2}$ \\
\hline Controls & & .04 & -.05 \\
\hline External LOC & $-.87 * *$ & .68 & .65 \\
\hline \multicolumn{4}{|l|}{ Mediation } \\
\hline & Step 1 & Step 2 & Step 3 \\
\hline & $\beta$ & $\beta$ & $\beta$ \\
\hline Gender & .175 & -.029 & .023 \\
\hline Age & .046 & -.023 & -.041 \\
\hline Category & -.018 & -.029 & .008 \\
\hline Experience & .015 & .021 & .016 \\
\hline Job Satisfaction & & $.84 * *$ & .48 \\
\hline External LOC & & & -.51 \\
\hline $\mathbf{R}^{2}$ & .04 & .82 & .88 \\
\hline$\Delta \mathbf{R}^{2}$ & & .63 & .10 \\
\hline
\end{tabular}

Direct effect of external locus of control shows huge variation in the dependent variable $\left(\beta=-.87, R^{2}=\right.$ $.68, \mathrm{P}<.01$ ) which shows the presence of mediator job satisfaction. In step 2 of table 2 with the introduction of mediator value of $\mathrm{R}$ square is 0.82 which shows out of total change in dependent variable 82 percent is due to job satisfaction. Positive sign of beta values $(\beta=0.84$,
$\mathrm{P}<.01$ ) shows their positive relation with the training transfer. However with the introduction of independent variable external locus of control their is huge drop in the beta values $(-0.87$ to -0.51$)$ and higher value of $\mathrm{R}$ square (0.68 to 0.88$)$ which shows the mediation of job satisfaction. Hence from the above results our H6 is accepted which states Job Satisfaction significantly mediates the relationship between external locus of control and training transfer.

Table 3 contains hierarchical regression analysis of external locus of control and training transfer with achievement motivation as mediator.

TABLE 3

Hierarchical Regression Analysis for External

Locus of control and Training Transfer with Achievement motivation as a Mediator

\begin{tabular}{lccc}
\hline \multicolumn{1}{c}{ Variables } & \multicolumn{3}{c}{ Job Satisfaction } \\
Direct Effect & $\boldsymbol{\beta}$ & $\mathbf{R}^{\mathbf{2}}$ & $\Delta \mathbf{R}^{\mathbf{2}}$ \\
\hline Controls & & 0.10 & 0.02 \\
External LOC & $-0.54^{* *}$ & 0.44 & 0.34 \\
\hline
\end{tabular}

\begin{tabular}{lccc} 
& \multicolumn{3}{c}{ Training Transfer } \\
& $\boldsymbol{\beta}$ & $\mathbf{R}^{2}$ & $\Delta \mathbf{R}^{2}$ \\
\hline Controls & & .04 & -.05 \\
External LOC & $-.87^{* *}$ & .68 & .65
\end{tabular}

Mediation

\begin{tabular}{lccc}
\hline & Step 1 & Step 2 & Step 3 \\
\hline \multicolumn{1}{c}{ Gender } & $\boldsymbol{\beta}$ & $\boldsymbol{\beta}$ & $\boldsymbol{\beta}$ \\
Age & .175 & .020 & .046 \\
Category & .046 & -.028 & -.051 \\
Experience & -.018 & -.055 & -.002 \\
Job Satisfaction & .015 & -.003 & .002 \\
External LOC & & $.94 * *$ & .53 \\
$\mathbf{R}^{2}$ & & & -.58 \\
$\Delta \mathbf{R}^{2}$ & .04 & .62 & .80 \\
\hline Note .LOC stands for Locus of Control, $* * P<.01$
\end{tabular}

Table 3 contains hierarchical regression analysis of external locus of control and training transfer with achievement motivation as mediator. In step 2 of table 3 with the introduction of mediator value of $\mathrm{R}$ square is 0.62 which shows out of total change in dependent variable 62 percent is due to job satisfaction. Positive sign of beta values $(\beta=0.94, \mathrm{P}<.01)$ shows their positive relation with the training transfer. However with the introduction of independent variable, i. e., external locus of control, there is huge drop in the beta values $(-0.87$ to -0.58$)$ and higher value of $\mathrm{R}$ square $(0.68$ to 0.80$)$ which shows the mediation of achievement motivation. 
Hence from the above results our H7 is accepted which states Achievement motivation significantly mediates the relationship between external locus of control and training transfer.

\section{DISCUSSION}

Our first hypothesis was that External Locus of control has significant Negative relation with Training Transfer, which is accepted. The literature had mixed findings which was precisely the reason for conducting this research to find out how this relationship exists in the context of Pakistani Culture. Our data proves that Training transfer has very strong association with locus of control, which is consistent with the conceptualization of Baldwin \& Ford (1988) and Colquitt et.al (2000). According to their conceptualization, the employees with high Internal Locus of control will have firm belief in their abilities therefore their learning will be enhanced as compared to those employees with high External Locus of control.

Our second hypothesis was that External Locus of control has significant Negative relation with Job Satisfaction, which was accepted. There is sufficient evidence in the literature which also supports our findings like Carrim, Basson \& Coetzee (2006) and Hans et. al (2013). Their findings highlighted that Job Satisfaction and Locus of control has strong association when studied together. Employees with external locus of control will be less satisfied from their jobs then the employees with internal locus of control.

Third Hypothesis states that External Locus of control has significant Negative relation with Achievement Motivation, which was also accepted in the light of the results we calculated. The literature has evidence the individuals' personality trait like strong desire to achieve has association with their belief on their abilities (Wigfield \& Eccles, 2000). Phillips and Gully (1997) also found that employees with Internal Locus of control had high level of motivation to achieve more goals and objectives in their life and at workplace, which is consistent with our findings.

The fourth hypothesis and fifth hypothesis were Job Satisfaction and achievement motivation has significant positive relation with Training Transfer, which were accepted significantly. Egan et. al (2004) found that motivation level and job satisfaction has very strong correlation with Training Transfer. This is also consistent with the findings of Colquit et al (2000), who reported that cognitive ability of the trainees were enhanced with job satisfaction and achievement motivation.

Our sixth and seventh hypothesis were on mediating effect of Achievement motivation and Job satisfaction on Training Transfer. Our data shows that both the mediator plays a role in our research model. Inozu et al. (2012) reported that Job Satisfaction and Achievement motivation were the dispositional factors which determine the employees' attitude at work. In 1997, Ford and Weissbein concluded that personality disposition like achievement motivation or job satisfaction has strong impact on individuals; motivation to learn during the training. Our findings also indicate that there is inverse relationship between External Locus of Control and Training Transfer. However in the presence of the mediators like Achievement motivation and job satisfaction the impact of negative relation between external locus of control and training transfer is reduced.

From the above discussion it is concluded that people with external locus of control have low level of job satisfaction as well as achievement motivation. Renn and Vadenberg (1991) reported that Internals were highly satisfied from their jobs as compared to externals that had frequent thoughts of quitting their jobs. Such attitude of Externals towards their jobs result in boredom and lack of interest in opportunities provided to them at work including trainings. Therefore, when they participate in any training opportunity their level of training transfer will also be low as compared to the people who have internal locus of control, because our results reveal that external locus of control negatively effects job satisfaction and achievement motivation which have negative effect on training transfer. It can also be concluded under the light of the above research that Internals will have better attitude towards their work with high levels of transferability of knowledge gained in the training sessions.

\section{REFERENCES}

Arthur Jr, W., Bennett Jr, W., Edens, P. S., \& Bell, S. T. 2003. Effectiveness of training in organizations: a meta-analysis of design and evaluation features. Journal of Applied psychology, 88(2), 234

Bandura, A. 1977. Social learning theory.

Baldwin, T. T., \& Ford, J. K. 1988. Transfer of training: A review and directions for future research. Personnel psychology, 41(1), 63-105.

Baumeister, R.F. 2008. Free will in scientific psychology. Perspectives on Psychological Science, 3(1), 1419.

Brayfield, A. H., \& Rothe, H. F. 1951. An index of job satisfaction. Journal of applied psychology, 35(5), 307.

Burke, L. A., \& Hutchins, H. M. 2007. Training transfer: An integrative literature review. Human resource development review, 6(3), 263-296.

Byrne, Z. S., Mueller-Hanson, R. A., Cardador, J. M., 
Thornton III, G. C., Schuler, H., Frintrup, A., \& Fox, S. 2004.Measuring achievement motivation: tests of equivalency for English, German, and Israeli versions of the achievement motivation inventory. Personality and individual Differences, 37(1), 203-217.

Carrim, N. M., Basson, J. S., \& Coetzee, M. 2006. The relationship between job satisfaction and locus of control in a South African call centre environment.

Carrasco González, A. M., Calvo Salguero, A., \& Salinas Martínez de Lecea, J. M. 2010. Relationship between work-family conflict and job satisfaction: The moderating effect of gender and the salience of family and work roles. African journal of business management, 4(7), 1247-1259.

Carr, A. 2011. Positive psychology.Routledge.

Cavaiola, A. A., \& DeSordi, E. G. (2000).Locus of control in drinking driving offenders and nonoffenders. Alcoholism Treatment Quarterly, 18(4), 63-73.

Cavaiola, A. A., \& DeSordi, E. G. 2000. Locus of control in drinking driving offenders and non-offenders. Alcoholism Treatment Quarterly, 18(4), 63-73.

Choo, S., \& Bowley, C. 2007. Using training and development to affect job satisfaction within franchising. Journal of Small Business and Enterprise Development, 14(2), 339-352.

Colquitt, J. A., LePine, J. A., \& Noe, R. A. 2000. Toward an integrative theory of training motivation: a meta-analytic path analysis of 20 years of research. Journal of applied psychology, 85(5), 678.

Egan, T. M., Yang, B., \& Bartlett, K. R. 2004.The effects of organizational learning culture and job satisfaction on motivation to transfer learning and turnover intention. Human resource development quarterly, 15(3), 279-301.

Ford, J. K., \& Weissbein, D. A. 1997. Transfer of training: An updated review and analysis. Performance improvement quarterly, 10(2), 22-41.

Ganster, D. C., \& Fusilier, M. R. 1989. Control in the workplace.

Goldstein, I. L., \& Ford, J. K. 2002.Training in organizations Belmont. CA: Wadsworth.

Grandey, A. A., Fisk, G. M., Mattila, A. S., Jansen, K. J., \& Sideman, L. A. 2005. Is "service with a smile" enough? Authenticity of positive displays during service encounters. Organizational Behavior and Human Decision Processes, 96(1), 38-55.

Hans, A., Mubeen, S. A., \& Al Ghabshi, A. S. 2013 A Study on Locus of Control and Job Satisfaction in Semi-Government Organizations in Sultanate of Oman.

Huang, H. I. 2007. Understanding culinary arts workers:
Locus of control, job satisfaction, work stress and turnover intention. Journal of Foodservice Business Research, 9(2-3), 151-168.

Inozu, M., Yorulmaz, O., \&Terzi, S. 2012. Locus of Control in Obsessive-Compulsive (OC) and Depression Symptoms: The Moderating Effect of Externality on Obsessive-Related Control Beliefs in OC Symptoms. Behaviour Change, 29(03), 148163.

Kirkcaldy, B. D., Siefen, R. G., Merbach, M., Rutow, N., Brähler, E., \& Wittig, U. 2007. A comparison of general and illness-related locus of control in Russians, ethnic German migrants and Germans. Psychology, health \& medicine, 12(3), 364-379.

Latham, G. P., \& Wexley, K. N. 1981. Increasing productivity through performance appraisal (p. 93). Reading, MA: Addison-Wesley.

Locke, E. A. 1976. The Nature and Causes of Job Satisfaction

Mahajan, N., \& Kaur, J. 2012. Relation Between Locus of Control of College Teachers and Their Job Satisfaction. International Journal of Applied Psychology, 2(5), 98-103.

McClelland, D. C. 1987. Human motivation. CUP Archive.

Munir, S., \& Sajid, M. 2010. Examining Locus of Control (LOC) as a Determinant of Organizational Commitment among University Professors in Pakistan. Journal of Business Studies Quarterly, 1(3), 78-93.

Noe, R. A. 1986. Trainees' attributes and attitudes: Neglected influences on training effectiveness. Academy of Management Review, 11(4), 736-749.

Ng, T. W., Sorensen, K. L., \&Eby, L. T. 2006. Locus of control at work: a meta-analysis. Journal of Organizational Behavior, 27(8), 1057-1087.

Nicholls, J. G. 1984. Achievement motivation: Conceptions of ability, subjective experience, task choice, and performance. Psychological review,91(3), 328.

Phillips, J. M., \& Gully, S. M. 1997. Role of goal orientation, ability, need for achievement, and locus of control in the self-efficacy and goal-setting process. Journal of Applied Psychology, 82(5), 792.

Renn, R. W., \& Vandenberg, R. J. 1991. Differences in employee attitudes and behaviors based on Rotter's (1966) internal-external locus of control: are they all valid?. Human Relations, 44(11), 1161-1178.

Rotter, J. B. 1966. Generalized expectancies for internal versus external control of reinforcement. Psychological monographs: General and applied,80(1), 1. 
Ryon, H. S., \& Gleason, M. E. 2013.The Role of Locus of Control in Daily Life. Personality and Social Psychology Bulletin, 0146167213507087.

Salazar, J., Pfaffenberg, C., \& Salazar, L. 2006. Locus of control vs. employee empowerment and the relationship with hotel managers' job satisfaction. Journal of Human Resources in Hospitality \& Tourism, 5(1), 1-15.

Shahzad, K., Sarmad, M., Abbas, M., \& Khan, M. A. (2011).Impact of Emotional Intelligence (EI) on employee's performance in telecom sector of Pakistan. African Journal of Business Management, 5(4), 1225-1231.

Spector, P. E., Cooper, C. L., Sanchez, J. I., O'Driscoll, M., Sparks, K., Bernin, P., ...\& Yu, S. 2002. Locus of control and well-being at work: how generalizable are western findings? Academy of Management Journal, 45(2), 453-466.

Spreitzer, G. M. 1996. Social structural characteristics of psychological empowerment. Academy of Management Journal, 39(2), 483-504.
Suárez-Álvarez, J., Campillo-Álvarez, Á., FonsecaPedrero, E., García-Cueto, E., \&Muñiz, J. 2013. Professional Training in the Workplace: The Role of Achievement Motivation and Locus of Control. The Spanish journal of psychology, 16, E35.

Twenge, J. M., Zhang, L., \&Im, C. 2004. It's beyond my control: A cross-temporal meta-analysis of increasing externality in locus of control, 19602002. Personality and Social Psychology Review, 8(3), 308-319.

Wilson, P. H., Strutton, D., \& Farris, M. T. 2002. Investigating the perceptual aspect of sales training. The Journal of Personal Selling and Sales Management, 77-86.

Wigfield, A., \& Eccles, J. S. 2000. Expectancy-value theory of achievement motivation. Contemporary educational psychology, 25(1), 68-81

Wrightson, K. J., \& Wardle, J. 1997. Cultural variation in health locus of control. Ethnicity \& Health, 2(1-2), 13-20. 


\title{
LEARNING THROUGH TRAINING AND ITS IMPACT ON EMPLOYEE PERFORMANCE; MODERATING ROLE OF JOB SATISFACTION AMONG BANKING SECTOR EMPLOYEES OF PAKISTAN
}

\author{
SAMINA KARIM \\ Mohammad Ali Jinnah University, Islamabad
}

\begin{abstract}
Performance has been largely studied by scholars in the past. Due to ever changing market standards, training sessions have become more important, and now, are more emphasized by the bank's management. This study identifies the training sessions, conducted by different banks in Pakistan, their impact on job satisfaction, and employee performance. Sample size consists of 119 employees, working at different levels in 6 banks, and data was collected through structured questionnaire. Findings suggest that effectiveness of training is largely dependent on trainer's quality, course design and learning experience. The results of the study will be helpful for the managers to increase the job satisfaction $\&$ performance of employees through training programs. This study, has added its humble contribution, in the body of knowledge, along with other studies conducted by other researchers in the banking sector of Pakistan. There is further need, to explore this area of study, to address job satisfaction and performance in this industry.
\end{abstract}

\section{INTRODUCTION}

Performance has been an area of interest for many scholars and researchers. Emerging competitive and dynamic market challenges require, special consideration, towards performance management. The Banking industry of Pakistan is becoming more profit driven and customer focused due to special emphasize on employees. Holzer, Stoll, and Wissoker (2004) suggested that poor performance causes financial loss and absenteeism, resulting in less employee turnover, and lack of motivation. Therefore, work related training helps in keeping pace, with the latest technology in the changing world dynamics. In Pakistan, the population is estimated to be about $18 \mathrm{M}$ as per 1998, with a growth rate of 2.2\% (Sathar, 2001), and literacy rate of $50 \%$ in females \& $65 \%$ in males, which is the lowest in this region (Education System of Pakistan, 2007, p. 38).

Dilemma, faced by the labor market of Pakistan, are two folds: (i) the major share of the population consist of the youth and, (ii) the labor force is facing a deficit not only in education, but also in skills, experience and employment opportunities. However, lack of education leads to create an imbalance in the demand and supply of skilled workers (Quraishi, 1997). In this regard, formal and informal training sessions are quite helpful. As mentioned, the study of Hong and Kean (2012) indicates that informal trainings yields better outcome than formal trainings. The Ultimate purpose of training is to align the goals of individuals and organizations in similar direction. Extensive training and intra organizational career supportive structure lead to improved performance, and work effectiveness (Zhang \& Li, 2009). Training is a motivational factor as highlighted by Herzberg (1959), recognition as motivating \& satisfying factor.

In the recent times, increase of complex jobs advocate the need for well trained \& experienced individuals in task performance (Karthikeyan et al, 2010). Organizations now heavily invest in training their employees; Training yield a positive relationship, with a greater degree of job satisfaction, which consequently lead to increased performance (Liao, Rice \& Martin, 2011; Nguyen, Trvong \& Buyens, 2011; Jones, Jones, Latreille, \& Sloane, 2009; Mohsan, Nawaz, Khan, \& Shaukat, 2012). To keep pace with competitors and latest technology, survival of organization is hidden underneath effective training sessions (Collier, Green, Kim, \& Peirson, 2011). Organizations and employees, both take benefit from training programs. However, management support to training sessions enables its employees to be self-sufficient and more skilled, ensuring better wages, improved performance, increased commitment and motivation for lower wage employees (Krurger \& Rouse, 1998; Neumark \& Wascher, 2001; Malik \& Malik, 2008). Feedback of training contents helps in redesigning the training programs. (Huque \& 
Vyas, 2008).

There are numerous reasons due to which organizations experience low job satisfaction, such as procedural injustice and pay levels (Williams, McDaniel, \& Nguyen, 2006), which have great influence on performance and employee turnover intentions. In view of Williamson, Pemberton, and Lounsbury (2005), personality-job match yields satisfied employees, who have more optimistic approach about career and growth.

TQM techniques (Easton \& Jarrell1, 1998) help in creating value, innovation and to attain improved levels of performance. Effectiveness of training can be determined by measuring change in performance, before and after training programs (Poulet, 1997). Moreover, past performance and future potential (Manasa \& Reddy, 2009) of employees will provide guidance for redesigning future training needs of the business. Different organizations use different performance measurement techniques, e.g. multidimensional performance measurement pay systems (Griffith \& Nelly, 2009). The basic objective of this study is primarily to analyze the training activities conducted in the banking sector organizations of Pakistan and to measure their effectiveness on performance. Secondly, to examine the change in performance due to training programs managed by the management team of the organization.

\section{REVIEW OF LITERATURE}

Banking sector plays a pivotal role in any economy to attain sustainable growth, economic efficiency and overall improvement in the financial system. Banking industry serves as the back bone and provides different financial assistance (Raza, Farhan, Usman \& Akram, 2011) in the country. Privatization of banks has a positive impact on this industry to be one of the lucrative, profit earners and competitive industry of the country. The recent flood (in 2010 and 2011), with adverse law and order situation of the country, has affected its growth rate in the latest years. The banking sector of Pakistan comprise of 36 commercial banks, that includes 25 local private banks, 4 public sector commercial banks, 7 foreign banks and 4 specialized banks with a total number of 9,087 branches throughout the country. The total number of operational Islamic banks was 6 by the end of June-2010 (Pakistan Banking sector, 2011, p 3).

Increasing job demands in banking sector has increased stress on employees (Rahim, 2010), while increased working hours (Afzal, Butt, Rehman, \& Safan, (n.d)) has worsened the situation. In a country like Pakistan, where the youth comprises the major share of its population, are faced by multiple problems e.g. lack of education, skills, experience, limited job opportunities and start of early career (Ahmed \& Azim, 2010) which is mainly due to negligible guidance and counseling (Inamullah, Naseeruddin, Hussain \& Shah, 2009).

Today, the largest investment in organizations (both local \& international) is on employee training due to the ever growing skill demand. Organizations usually spend billions on training, but they fail to attain performance improvements because of inability to transfer training to the individuals \& workplace (Burke \& Baldwin, 1996; Burke \& Hutchins, 2008). For this purpose, supervisor - support may prove to be helpful (Klink, Gielen, \& Nauta, 2001; Velada, Caetano, Michel, Lyons, \& Kavanagh, 2007), as a high level of relationship between supervisor \& subordinates is a source of motivation for the employees. Keeping the above data in view, training can be described as a process of acquiring knowledge, skills \& expertise, by a person, to perform an assigned task/job effectively.

As Choo and Bowley (2007) studied that training is linked with the employee's productivity, which ultimately result in customer satisfaction; they suggested effective training outcome as increased productivity. A positive relationship between Training, work place performance and employee job satisfaction (Jones et al., 2009) is witnessed; however, this relationship depends on multiple factors. Some of the factors are trainer's quality, which plays a vital role as it directly affects training success. Trainer's quality ensures about program's success or failure. Apart from trainer's quality: course design, learning / experience of trainers \& transfer of training, affect the quality and quantum of training.

In fact training is a positive way of bringing consistency \& change in attitude. Rowden, (2007) suggested that training improves employee's morale and also help in maintaining high level of productivity. Every organization has its own purpose of training as indicated by Baldwin and Johnson (1995). The purpose of training in any organization is, i) to follow the company's strategy, ii) to bring innovation and iii) to bring technological advancement. Likewise every industry/ job has different demands for skills and capabilities (Baldwin, 1999; Huselid, Beatty \& Becker, 2005), which require different training strategies for diverse skills according to their objectives. Usually, skills-based trainings involve one or more of the five basic methods, i.e. lecture case study, role play, behavioral modeling and simulations while on the other hand, in non- skills-based training method, behavioral modeling method is considered to be the most important. Level of training sessions is also important (Thomas, 2000), as low level of training result in increased turn over, while on the contrary, extensive training increases employee satisfaction \& keeps them retained. 
Human beings, being the most important asset, take training as a positive notion. Employers, who do not charge for conducting training programs (Pischke, 2000) for their employees, work out to be more productive and practicing. Training can be classified into two categories, i) General Training and ii) Specific training. Both have separate returns to organizations (Barrett \& O'Connell, 1999). They further elaborated that general trainings have positive effects on organizations productivity, while no such relationship exist in case of specific trainings. Additionally, it was concluded that training is beneficial for the current employers as well as the future employers. There are also training programs which can be on-the-job trainings and off- the-job trainings.

Pfeffer (2006) observed that a company (a kidney dialysis center in USA) Davita, with more than 35000 employees, believes in empowering employees. Davita invests heavily in training and spends more than $\$ 10$ million/year on trainings and resultantly face fewer turnovers, save on attrition cost and give improved patient care. Similarly, empowered employees result in better service quality and customer satisfaction (Abbasi, Khan, \& Rashid, 2011).

For any organization, employees are a source of substantial competitive advantage (Becker \& Huselid, 2006; Huselid, Jackson, \& Schular, 1997) as indicated by SHRM (Strategic Human Resource Management), and employee's contribution towards firm's objective is mainly contributed by their uniqueness and value. Therefore, humans require more consideration than what was in the past. A recent study indicates a change in CEOs role in terms of time distribution i.e. $20 \%$ and sometimes $50 \%$ time is spent on talent issues now (Economist Intelligence Unit, 2006).

\section{Quality of Trainer}

Training serves as a source of motivation (Smits, 2006), so trainer specifications should be given special deliberations. The aim of this study is to identify the quality of trainer and its impact on level of motivation \& employee productivity. This study highlights the importance of training to the companies to seek guidance, and design their future strategies for provision of better training programs in order to generate qualified $\&$ skilled workers with a higher degree of productivity. A non-experimental program by Chong and Galdo (2006), analyzed the effect of training on labor market and concluded that the higher the quality of trainer, the greater the average and marginal output will be.

Choo and Bowley, (2007) suggested that the level of training is essential, as higher level of trainings increases the employee satisfaction and their loyalty with the firm, and decreases the chances of employee turnover. Their study focused on the relationship between training \& employee's productivity which lead to employee \& customer satisfaction. They also emphasized, that the quality of a trainer is a key element, which can affect the training productivity \& employee motivation. Training has different impacts on males and females. Hence, gender discrimination can possibly be a reason to avoid training programs designed to earn better wages. Therefore, carefully designed training programs lead to increase individual capabilities and skills.

Role of coach/ trainer can change group's operations and efficiency. Therefore, there is a need for inclusion of an environment, which is mutually beneficial for the trainer and trainee. Formal and informal trainings help both part time and full time employees (Nelen \& Grip, 2009). However, the relationship between coaching \& performance, employee - satisfaction and work place learning needs to be explored further (Tansy \& Cohen, 2001). In Pakistani context, trainer quality has been studied on a limited scale.

\section{Hypothesis 1. Job satisfaction significantly moderates the relationship between quality of trainer \& employee performance.}

\section{Course Design}

Trainings are a source of motivation, however low and carelessly designed training programs increase the likelihood of employee de-motivation perk up turnover (Baldwin \& Johnson, 1995). There are different training techniques which are used for labor force i.e. learning principles \& teaching skills, goal setting (Houghton \& Diliello, 2005) and self-management. (Tziner, Fisher, Senior \& Weisberg, 2007.). Ibarran, Rosas and Soares (2006) research reported that training programs enable employers to determine whether the training program has increased the employee's participation in employment utility or not.

An experimental study conducted by Erbas, Iftar and Yucesoy (2006) involves systematic teaching designs for students, who participated in training and development program for mentally retarded persons. An alternative treatment design was adopted to cope with the effectiveness of these two techniques. The most appropriate use of reinforcement and proper use of prompts were identified as teaching skills. The basic consideration while designing a training course should be given to identify the gap between firm's existing and future position (Brown \& Campbelli, n.d.). He also focused on the need of effective trainer, to fulfill the training needs. However, with the emergence of rapid change in technology, it is important to be more thoughtful and practical while designing a training 
program (Vosniadou \& Kollias, 2000). In this regard, frequent reassessments and re-teachings are vital, as exactly correct technique usually deteriorates over time. To gain maximum output from training sessions, training methodology should be consulted by trainees (Schmidt, 2007), as this has proved to be more productive and satisfying for trainees.

\section{Hypothesis 2. Job satisfaction significantly} moderates the relationship between course design \& employee performance.

\section{Learning Experience}

Employees' training and development is influenced by different aspects of work life e.g. experience, training and job tenure (Dougherty, 2000). New techniques emerged with the passage of time, but role of training is distinct. The main objective of HRD (Human Resource Development) is to improve the capabilities of individuals and enable them to learn \& overcome the barriers they face in such a way, as to promote a culture of continuous learning and rewarding that learning. Continuous learning provides employees the reason to stay in the organizations. Organizations endeavor for training in order to improve performance, as performance is a way to measure the success of a training program. Trainees' reaction helps to make the training programs interesting as well as serve as a source of motivation, enabling an effective transfer of training. Usually, learners have a positive attitude towards learning as evidenced by the study conducted by Awan (2009). However, if employee's expectations from training course are not fulfilled, it will result in a low level of transfer of training (Hicks \& Klimoski, 1987). Measurement of learning performance can be measured by recalling training material after completion of training programs.

Organizations invest heavily on training and sometimes are unable to reap the expected results. At times, lack of opportunity to implement newly learned skill is the biggest barrier towards successful implementation of training (Clarke, 2002). Trainee's reactions are important, to have additional insight for the relationship between training \& employee performance. Training serve two purposes: first, investing in employees with new knowledge skills, thus offering them to further develop themselves \& perform more effectively, secondly, reactions of trainees are influenced by their mood, emotions and level of motivation, which leads to the success or failure of the training programs.

Feedback regarding newly acquired knowledge $\&$ its applicability increases the probability of its transfer to a workplace (Velada et al., 2007). Moreover, accountability of training activities may also bring positive results
(Saks \& Belcourt, 2006). It is observed that experienced employees belonging to a low income bracket are more responsive to training, found training useful to perform office work and expect a raise in salary after training; while officers \& managers on the contrary, do not expect this. Therefore, special attention is required before engaging any worker in training. Frequent and fluent communication among leader \& subordinate increased trust, empowerment and performance, while the level of job involvement \& career planning proved to be helpful in transfer of training. It becomes useless if performance remain unaffected.

\section{Hypothesis 3. Job satisfaction positively moderates the relationship between transfer of training \& employee performance}

\section{Training Outcome}

Acemoglu and Pischke (1999) discussed on the job training, general training and external and internal certification of training to conclude that such a certification may bring discrimination between good employees and normal employees. Mentoring programs are used to increase job satisfaction by many organizations. There exist a positive relationship between training and job satisfaction for a variety of occupational categories (Hamlin, Ellinger \& Beattie, 2008). The ultimate objective of any training program is to improve performance \& motivation, which is affected by many factors e.g. equipment, raw material, and economic environment (Leung, 2006). Management should design training programs which have strong links with the strategic objectives of the business, as it tend to promote successful transfer of training to the work performance (Holton, Bates \& Rouna, 2000), and if they are not integrated with business objectives, resultant performance of employee will not be of any value (Swanson, 1995). Blumberg and Pringle (1992) indicate that performance is a function of employee capacity (ability, health, education etc.), their willingness (motivation, job satisfaction etc.) and opportunity to perform (tools, equipment, working conditions etc.).

Usually, organizations are only concerned about their profits, and this approach has harmful effects on individuals, families and societies (Pfeffer, 2009), leading to work family conflict. Lee and Jeong (2011) observed impacts of downsizing on profitability and concluded that it has negative effect such as low morale and motivation. Job Competition in the global market has increased, leaving individuals with the emergence of boundary-less careers (Kanter, 1989) mainly due to organizational inability to offer internal career opportunities to its employees. 


\section{Employee Job Satisfaction}

Many researchers worked on job satisfaction and they were always interested to know the causes and factors responsible for job satisfaction. Training is basically an opportunity given to the talented employees to utilize their skills and stay fixed to their jobs. Through training, employees try to improve their behavior, skills and performance. Employee satisfaction from jobs is a great matter of concern for managers (Batool \& Batool, 2012), while training bestow on employees a feeling of great self-confidence, satisfaction, dignity, self-worth and feeling of being valuable for the organization \& society.

Job satisfaction is deeply influenced by organizational environment. A good match between organizational environment \& personal characteristics of the employee results in satisfaction with the job. Ramlall (2004) discussed, that a pleasant work environment helps to satisfy employees, which ultimately induce them for a better performance. Satisfied employees will exert all their efforts to achieve organization's objectives, to earn good will of the management and stay retained. A satisfied employee is good in productivity (Murray, 1999) and helps in implementing Human Resource Management systems and devising strategies (Halepota, 2008). He further identified few factors i.e. procedural justice, individual \& psychological factors which gives birth to absenteeism, low performance as well as cut in productivity. Moreover, there are factors other than training, which strongly impact job satisfaction, e.g. compensation package, supervision and career growth (Ashraf, Joarder and Masum, 2008).

Dissatisfaction at jobs may result in severe outcomes e.g. absenteeism, poor mental \& physical health of employees, decrease in employee turnover and continuous employee complaints. Therefore, element of job satisfaction is still important enough to be considered (Judge, Thoreson, Bono, \& Patton, 2001).

\section{Employee Performance}

Role of HR department is vital to meet organizational interests by attending employee's interests e.g. their skill requirements, motivations and quality of job (Boselie, Dietz \& Boon, 2005). All this is considered a critical component of business strategy. Effective training not only saves attrition cost but also benefits in many other aspects. Organization fit approach and job fit approach help in increasing satisfaction level (Brown, Zimmerman, \& Johnson, 2005; Meglino, Ravlin \& Adkin, 1992). Non-availability of skilled workers is a barrier towards technological advancement \& innovation (Baldwin \& Sabourin, 1995), which substantially increase cost of training. They also advocate that enhanced performance can be achieved in two ways, either by recruiting new $\&$ highly skilled employees or improving skills of existing employees.

There are several positive outcomes of training; few of them are commitment, increased information and training reputation (Brown et al, 2005). Higher training levels achieve higher level of performance (Guest, 1997). Training sessions are conducted to enable employees to meet specific situations, and to perform various tasks in current $\&$ future scenario. In this view, the fastest growing firms require an extensive training activity that is complementary to an innovative strategy.

It is expected, that the result of training tends to reduce stress, tension \& negative emotion; while on the other hand, it promotes positive emotions, communication, job satisfaction, increased performance and high commitment. Employee satisfaction helps in increasing employee performance and increase in turnover (Choo \& Bowley, 2007). Organizations now emphasize more on training (Batool \& Batool, 2012), because organizations cannot produce better results without the inclusion of proper training \& development. However, results of trainings mainly rely on the worker feedback and their working style.

Caldieraro and Coughlan, (2002) studied training needs of the sales persons of manufacturing $\&$ marketing firms. It is necessary for these firms to prepare their teams according to future business needs, otherwise it will be difficult to conform to the market requirements and transfer their complex products to the end users. It is emphasized that training is vital for such industries. Training needs depends upon the nature of the business. The companies which are based on innovative technologies are found more concerned about training their staff (Baldwin, 1999). Researchers are focused on more specific research to be conducted for training needs (Cohen, 2005).

\section{Hypothesis 4. The higher the job satisfaction with the organization's provision of training, the higher an employee's job performance.}

\section{THEORETICAL FRAMEWORK}

The theoretical framework is designed to carry out this research study. As in the banking sector of Pakistan, there is plenty of need to improve the communication skills of the peers, to increase corporate profit, emphasize on excellent services, positive working relationship and many more. As a result, there is a need to manage the knowledgeable workers by an efficiently managed human resource techniques (Sharif, Ahmad \& Kausar, 2011). 
By training, the existing skills of the employees are refined and also help employees to learn new skills and techniques. Training is one of the sources to bring satisfaction among the employees. Organizations today invest quite a huge capital on its employees to improve them. However, it is important to properly utilize this investment and to get maximum benefits from these training programs. In this regard, initial training and work design plays an important role (Kupritz, 2002), and more research should be conducted on the need analysis to identify obstacles in training transfer $\&$ how this can be increased (Holton et al., 2000)

Empowered employees stipulate improved performance. In this regard the role of trainer is very important in managing a training program. Quality of trainer is among one of the factors that can strongly affect trainings. Trainer's quality varies from trainer to trainer. In this view, presentation skills, training environment, knowledge, \& command over the topic under discussion determine the trainer's quality. Course design is also very much important, therefore, tools \& techniques need to be utilized in a successful manner. Course design may be developed in view of on-the-job training or off- the job training. Another determinant of training is learning experience. This reflects how training program was and how much trainee's learnt from it. All these determinants affect employee satisfaction and performance from training programs. Combination of these factors, if rightly mixed, will satisfy employee otherwise it may have a negative impact on employees. If an employee feels, that the organization is focusing on the development of the employee, this will end up in higher commitment to the organization.

FIGURE 1

\section{Conceptual Model}

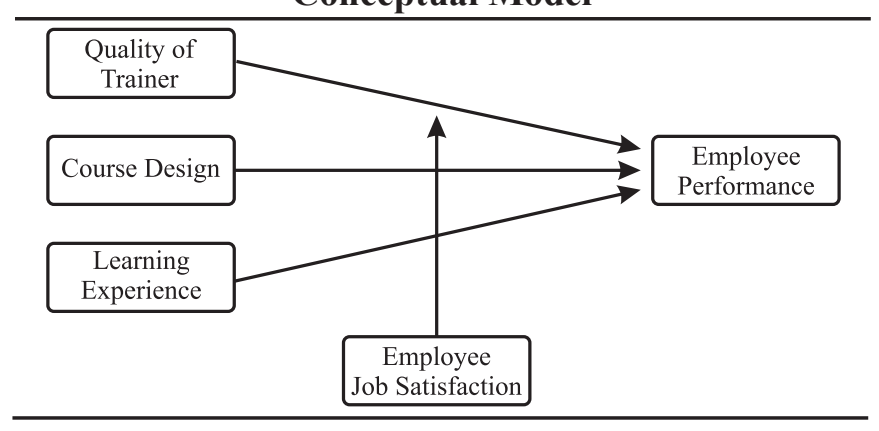

\section{METHODOLOGY}

Intention of researchers is to study the training and development activities carried out in banking sector organizations of Pakistan. The sample size for this study was determined as 150 questionnaires and 119 were received after getting filled by the seven (7) different banks including Soneri bank, Faysal Bank, Bank Al-
Falaha, Askari Bank, Allied Bank, Bank of Punjab and NIB, which were selected for this study. Primary data was collected through a structured questionnaire distribution. Questionnaire of the study has been composed from the questionnaire of Choo and Bowley (2007), Lindgren and Paulsson (2008), and Tessema and Soeters (2006). Wherein certain necessary changes were made as required by the study. The questionnaire consists of two main sections. The first section carries demographic information i.e. age, gender, qualification and working experience and the second section contains questions regarding variables. The questionnaire contains 19 items devoted to training facets, 7 for job satisfaction and 4 for employee performance. The analysis is based on multiple regression analysis and simple $\&$ moderated correlation analysis.

\section{RESULTS \& DISCUSSION}

The table mentioned below represents the demographic aspects of the study. This study helps in understanding the impact of training $\&$ development on job satisfaction and employee performance in banking industry of Pakistan. One of the objectives of commercial banks is to retain their skilled workers \& attain high performance. The study includes 119 questionnaires filled by 7 different banks \& their different branches. The results indicate a positive \& significant relationship between training facets, job satisfaction and employee performance.

TABLE 1

Demographics

\begin{tabular}{lll}
\hline Age & Frequency & Percent \\
\hline $20-30$ & 52 & 43.7 \\
$30-40$ & 47 & 39.5 \\
$40-50$ & 11 & 9.2 \\
50 and above & 9 & 7.6 \\
Total & 119 & 100 \\
\hline Gender & Frequency & Percent \\
\hline Male & 74 & 62.2 \\
Female & 45 & 37.8 \\
Total & 119 & 100 \\
\hline Education & Frequency & Percent \\
\hline Intermediate & 4 & 3.4 \\
Graduation & 35 & 29.4 \\
Post Graduate & 80 & 67.2 \\
Total & 119 & 100 \\
\hline Experience & Frequency & Percent \\
\hline $1-3$ & 24 & 20.2 \\
4-6 & 38 & 31.9 \\
$7-9$ & 24 & 20.2 \\
$10-12$ & 15 & 12.6 \\
$13-15$ & 9 & 7.6 \\
16 \& above & 9 & 7.6 \\
Total & 119 & 100 \\
\hline & & \\
\hline & 45 & \\
\hline
\end{tabular}


The significant relationship between Trainer quality and job satisfaction (correlated at $60.5 \%$ ) \& performance (correlated at 69\%) indicates the need \& importance of trainerin success of training sessions. The knowledgeable, supportive and experienced trainers help to increase job satisfaction. Resultantly, satisfied employees from training \& performance of trainer are likely to experience high level of job satisfaction \& enhanced performance (correlated at 69\%). This study also highlights two other factors, i.e. course design \& learning experience and their influence on job satisfaction (correlated at $64.8 \%$ $\& 73 \%$ respectively ) and performance (correlated at 69\%). Employees develop positive feelings when they get trained. These results reflect the significance of training. When banks train their employees according to what they lack in skill requirement, banks must try that the employees get a positive learning experience from the trainings conducted. It is important that banks should pay special considerations towards design of the course, as this factor affects the trainings heavily. From correlation analysis, it is found that quality of trainer course design and learning experience largely affects job satisfaction \& performance of employees. Results also indicate that satisfied employees perform better than unsatisfied employees. Therefore, banks should pay utmost attention \& effort to satisfy their employees to achieve maximum performance. " $t$ " value i.e. above 2 shows significant relationship and all the hypotheses are accepted. Moreover, Beta value reports the changes in dependent variable due to independent variables.

TABLE 2

\section{Correlation Analysis}

\begin{tabular}{ccccc}
\hline $\begin{array}{c}\text { Quality } \\
\text { of } \\
\text { Trainer }\end{array}$ & $\begin{array}{c}\text { Course } \\
\text { Design }\end{array}$ & $\begin{array}{c}\text { Learn- } \\
\text { ing } \\
\text { Experi- } \\
\text { ence }\end{array}$ & $\begin{array}{c}\text { Job } \\
\text { Satisfac- } \\
\text { tion }\end{array}$ & $\begin{array}{c}\text { Em- } \\
\text { ployee } \\
\text { Perfor- } \\
\text { mance }\end{array}$ \\
\hline
\end{tabular}

\begin{tabular}{|c|c|c|c|c|c|}
\hline $\begin{array}{l}\text { Quality of } \\
\text { Trainer }\end{array}$ & 1 & & & & \\
\hline $\begin{array}{l}\text { Course } \\
\text { Design }\end{array}$ & $.828 * *$ & 1 & & & \\
\hline $\begin{array}{l}\text { Learning } \\
\text { Experience }\end{array}$ & $.747 * *$ & $.710^{* *}$ & 1 & & \\
\hline $\begin{array}{l}\text { Job } \\
\text { Satisfaction }\end{array}$ & $.605^{* *}$ & $.648 * *$ & $.730 * *$ & 1 & \\
\hline $\begin{array}{l}\text { Employee } \\
\text { Performance }\end{array}$ & $.458 * *$ & $.448 * *$ & $.541^{* *}$ & .690 ** & 1 \\
\hline
\end{tabular}

Moderating effects of job satisfaction on the predictor and dependent variables are evidenced in the appended table. Job satisfaction has changed the values of $\mathrm{R}$ and $\mathrm{R}$ square positively which is a representative of positive impact of moderator. Moreover, job satisfaction moderates the training facets positively and strengthens the relationship between predictor, moderator and dependent variable. Therefore, the overall impact of job satisfaction on employee performance is significant.

TABLE 3

Regression Analysis

\begin{tabular}{lccc}
\hline Predictor & \multicolumn{3}{c}{ Performance } \\
& $\boldsymbol{\beta}$ & $\mathbf{R}^{2}$ & $\Delta \mathbf{R}^{2}$ \\
\hline Moderation & & & \\
Step 1 & & & .203 \\
QT & 458 & .210 & $.475^{* *}$ \\
JS x QT & 1.144 & .484 & .194 \\
CD & .448 & .201 & $.441^{* *}$ \\
JS x CD & 1.148 & .450 & .286 \\
LE & .541 & .292 & $.454^{* *}$ \\
JS x LE & 1.072 & .464 &
\end{tabular}

Here $Q T=$ Quality of Trainer, $C D=$ Course design, $L E=$ Learning Experience and JS= Job satisfaction

** Correlation is significant at the 0.01 level (2-tailed)

\section{CONCLUSION}

This study is an effort to highlight the implications of trainings and job satisfaction and its role in employee performance of banking industry of Pakistan. Banking sector is one of the fastest growing industries of Pakistan; usually overlooks its employee trainings due to more time devotion requirements towards customer services, work overload and increasing role demands. Little time \& effort is devoted towards employees training \& job satisfaction by the management. However, to achieve the objective of high performance, it is not only essential but vital to keep the employees at a satisfied level, which requires special strategies to be adopted on the part of the management of these banks. Thus, it is concluded that quality of trainer has positive \& significant impact on employee's job satisfaction \& performance. Other two variables under study (course design \& transfer of training) both specify positive relationship with job satisfaction \& performance.

However, this study will be helpful for the management of the banks to design and develop their employee's skill as per future need and role demand $\&$ also helps them in maintaining performance level. The limitation of the study were limited time available, sample was not representative of population and hurdles in data collection due to Employees business in their routine tasks and it was hard to get questionnaire filled from them.

\section{FUTURE RESEARCH DIRECTIONS}

Findings of this research study will create opportunities for higher management of the banks to 
enhance job satisfaction by conducting efficient training programs that fulfill employees' needs. It is also to be cared for that the employees and their interests are aligned with the strategies of the banks, to remain on the same track. Another important element to be viewed while conducting trainings is that trainings can only be regarded as successful if they meet employee's expectations from such sessions. Moreover, in future the researchers may analyze trainings and their impact on other industry segments with other facets of training. There are numerous other factors which influence job satisfaction; the future researchers may also consider them while discussing job satisfaction of banking sector of Pakistan.

\section{REFERENCES}

Abbasi, M.M., Khan, M.M. \& Rashid, K. 2011. Employee Empowerment, Service Quality and Customer Satisfaction in Pakistani Banks. The IUP Journal of Bank Management, Vol. X, No. 4.

Acemoglu, D., \& Pischke, J. S. 1999. Beyond Becker: training in imperfect labour markets. The Economic Journal, 109(453), 112-142.

Afzal, H., Butt, B. Z., Rehman, K. \& Safwan, N. (n.d.). An investigation of intragroup Conflict and its impact on employees performance in Pakistani banking sector. South Asian Journal of Management.

Ahmed, R. \& Azim, P. 2010, Youth population and the labour market of pakistan: a micro Level study. Pakistan Economic and Social Review, volume 48, no. 2, pp. 183-208.

Ashraf, M. A., Joarder, M.H.R., and Al-Masum, R. 2008. Job Satisfaction of the Employees in the Mobile Phone Corporates in Bangladesh: A Case Study. (No. AIUB-BUS-ECON-2008-22). American International University-Bangladesh, Office of Research and Publications (ORP).

Awan, M. I. 2009. Development of a model for training literacy personnel in Pakistan (Doctoral dissertation, Open University).

Baldwin, J, R. \& Sabourin, D. 1995. Technology Use and Industrial Transformation: Empirical Perspective. Presented to the conference entitled "Technology, Information, and Public Policy" at the John Deutsch Institute for the Study of Economic Policy, Queen's University.

Baldwin, J. R. \& Johnson, J., 1995. Human Capital development and innovation: the case of training in small and medium sized-firm.

Barrett A. \& O' Connell, P. J. 2001. Does Training Generally Work? The Returns to In-Company Training. Industrial and Labour Relations review, Vol. 54, No. 23.
Batool, A. \& Batool, B. 2012. Effects of employees training on the organizational competitive advantage: Empirical study of Private Sector of Islamabad, Pakistan. Far East Journal of Psychology and Business, Vol, 6, No.1.

Becker.B. E. \& Huselid, M.A. 2006. Strategic Human Resource Management: Where do we go from here?. Journal of Management, Vol. 32 No. 6, 898925.

Blumberg, M. \& Pringle, C.D. 1992. The Missing opportunity in organizational Research: some Implications for a theory of Work Performance. Academy of Management Review, 7,560-69.

Boselie, P., Dietz, G. \& Boon, C. 2005. Commonalities and contradictions in HRM and performance research. Human Resource Management Journal, 15, 67-94.

Brown, C. \& Campbelli, (n.d). Technological Change, Training, and Job Tasks in a High-Tech Industry.

Brown, K. A. L., Zimmerman, R. D. \& Johnson, E.C. 2005. Consequences of individual's Fit at work: A meta-analysis of person-job, person-organization, person-group and person-supervisor fit. Personnel psychology, 58, 281-342.

Burke, L.A., \& Baldwin, T. T. 1996. Improving transfer of training: a field investigation of the effects of relapse prevention training and transfer climate on maintenance outcomes. Academy of Management Proceedings.

Burke, L. A., \& Hutchins, H. M. 2008. A study of best practices in training transfer and proposed model of transfer. Human Resource Development Quarterly, 19(2), 107-128.

Caldieraro, F. \& Coughlan, A. T. 2002. Channel Training Strategies in High Technology Industries. Kellogg School of Management Northwestern University.

Chong, A. \& Galdo, J. 2006. Does the Quality of Training Programs Matter? Evidence from Bidding Processes Data. Discussion Paper No. 2202.

Choo, S. \& Bowley, C., 2007. Using training \& Development to affect Job satisfaction within franchising. Journal of small business \& enterprise development, Vol. 14, PP. 339-352

Clarke, N. 2002. Job Work environment factors influencing training effectiveness within a human service agency: Some indicative support for Baldwin and Fords' transfer climate construct. International Journal of Training and development, 6(3), 146-62.

Collier, W., Green, F., Kim, Y. B. \& Peirson, J. 2011. Education, training and economic performance: evidence from establishment survival data. Labor Res 32:336-361.

Cohen, M. 2005. Negotiation and training: A study in 
Multi-Cultural Montreal. Concordia University, Canada.

Dougherty, C., 2000. Impact of Work Experience and Training in the Current and Previous occupations on Earnings: Micro Evidence from the National Lon Longitudinal Survey of Youth. Centre for Economic Performance London School of Economics and Political Science.

Easton, G. S. \& Jarrell. S. L. 1998. The Effects of Total Quality Management on Corporate Performance: An Empirical Investigation. The Journal of Business, Vol. 71, No. 2, pp. 253-307.

Economist Intelligence Unit. 2006. Operating Risk in emerging market.

Education system of Pakistan. 2007. UNESCO

Erbas, D., Iftar, E. T. \& Yucesoy, S. 2006. Teaching Special Education Teachers How to Conduct Functional Analysis in Natural Settings. Education and Training in Developmental Disabilities, 41(1), 28-36.

Griffith, R. \& Nelly, A. 2009. Performance Pay and Managerial Experience in Multitask Teams: Evidence from within a Firm. Journal of Labor Economics, vol. 27, No. 1, pp. 49-82.

Guest, D. E. 1997. Human Resource Management and Performance: a review and research Agenda. International Journal of Human Resource Management, 8, 3, 263-76.

Halepota J. 2008. How to enhance job satisfaction ratings of public Sector employees? Thesis submitted for the Degree of Doctor of Philosophy.

Hamlin, R. G, Ellinger, A. D., \& Beattie, R. S., 2008. The emergent 'coaching industry': a wake-up call for HRD professionals. Human Resource Development International, Vol. 11, No. 3, 287-305.

Hicks, W.D. \& Klimoski, R. J. 1987. Entry into training programs and its effects on training outcomes: A filed experiment. Academy of Management journal 30(3), 542-552).

Holton III, E. F., Bates, R. A. \& Ruona, W. E. A. 2000. Development of generalized learning transfer system inventory. Human resource development, Quarterly, Vol. 11, no. 4.

Holzer, H. J., Stoll, M. A. \& Wissoker, D. 2004. Job Performance and Retention among Welfare Recipients. Social Service Review, 78 (3), pp. 343369.

Hong, T. T. \& Kean, L. Y. 2012. Organizational Commitment as a Moderator of the Effect of Training on Service Performance: An Empirical Study of Small- to Medium-Sized Enterprises in Malaysia. International Journal of Management Vol. 29 No. 1 Part 1.

Huque, A.S. \& Vyas, L. 2008. Expectations and performance: assessment of public service training in Hong Kong. The International Journal of Human Resource Management, Vol. 19, No. 1, 188-204.

Houghton, J. D. \& Diliello, T. C. 2005. Maximizing organizational leadership capacity for the Future; Toward a model of self-leadership, innovation and creativity. Journal of Managerial Psychology Vol. 21 No. 4, pp. 319-337.

Huselid, M. A., Beatty, R. W., \& Becker, B. E. 2005. 'A Players' or 'A Positions'?. Harvard Business Review, 83(12), 110-117.

Huselid, M. A., Jackson, S. E. \& Schular, R.S. 1997. Technical and strategic human resource management effectiveness as determinants of firm performance. Academy of Management Journal, Vol. 40, No. 1, 171-188.

Ibarran, P., Rosas, D. \& Soares Y. 2006. Impact Evaluation of a Youth Job Training Program in the Dominican Republic. Ex- Post Evaluation Report of the Labor Training and Modernization Project (DR0134).

Inamullah, H. M., Naseeruddin, M., Hussain, I. \& Shah, S. I. 2009. The Development Of Technical Education in Pakistan. International Business \& Economics Research Journal.

Jones, M. K., Jones, R. J., Latreille, P.L. \& Sloane, P. J. 2009. Training, Job Satisfaction, and Workplace Performance in Britain: Evidence from WERS 2004. Journal compilation (C) CEIS, Fondazione Giacomo Brodolini and Blackwell Publishing Ltd. Judge, T.A., Thoreson, C. J., Bono, J.E. \& Patton, G. K. 2001. The Job Satisfaction-Job Performance Relationship: A Qualitative and Quantitative Review. Psychological Bulletin, Vol. 127. No. 3. 376-407.

Kanter, R. M. 1989. When giants learn to dance: Mastering the challenge of strategy \& management, and careers in the 1990s. New York Simon and Schuster.

Klink, M. V. D., Gielen, E. \& Nauta, C. 2011. Supervisory support as a major condition to enhance transfer. International Journal of training \& Development.

Krurger, A. \& Rouse, C. 1998. The Effect of Workplace Education on Earnings, Turnover, and Job Performance. Journal of Labor Economics, Vol. 16, No. 1, pp. 61-94.

Kupritz, V. W. 2002. The relative impact of workplace design on training transfer. Human Resource Development Quarterly, 13,4, 427-47.

Leung, A. 2006. A conceptual model of information technology training leading to better Outcome. International Journal of Business \& Information, Volume 1 number 1, PP 74-95.

Lee, S. Y. \& Hong, J. W. 2011. Does Family-Friendly 
Policy Matter? Testing Its Impact on Turnover and Performance. Public Administration Review, 71(6), 870-879.

Liao, T. S., Rice, J. \& Martin, N. 2011. The role of the market in transforming training and knowledge to superior performance: evidence from the Australian manufacturing sector. The International Journal of Human Resource Management, Vol. 22, No. 2, 376-394.

Lindgren, L. \& Paulson, S. 2008. Retention- An explanatory study of Swedish employees in the financial sector regarding leadership style, remuneration and elements towards job satisfaction.

Malik, K. P. \& Malik, S. 2008. Value Creation Role of Knowledge Management: a Developing Country Perspective. The Electronic Journal of Knowledge Management Volume 6, pp. $41-48$.

Manasa. K. V. L. \& Reddy. N. 2009. Role of Training in Improving Performance. The IUP Journal of Soft Skills, Vol. III, Nos. 3 \& 4.

Meglino, B. M., Ravlin, E. C. \& Adkins, C. L. 1992. The measurement of work value congruence: A field study comparison. Journal of Management, Vol. 18, No. 1.

Mohsan, F., Nawaz, M. M., Khan, M. S. \& Shaukat, Z. 2012. Action Learning: A Positive Predictor of Motivation and Commitment for Bankers in Pakistan. International Journal of Business and Management Vol. 7, No. 2.

Murray, R. A. 1999. Job Satisfaction of Professional and Paraprofessional Library Staff. At the University of North Carolina at Chaper Hill.

Nelen, A., \& De Grip, A. 2009. Why Do Part-time Workers Invest Less in Human Capital than Fulltimers?. Labour, 23(s1), 61-83.

Neumark, D. \& Wascher, W. 2001. Minimum Wages and Training Revisited. Journal of Labor Economics, Vol. 19, No. 3, pp. 563-595.

Nguyen, T. N., Truong, Q. \& Buyens, D. 2011. Training and firm performance in economies in transition: a comparison between Vietnam and China. Asia Pacific Business Review, Vol. 17, No. 1, 103-119.

Pakistan Banking sector, 2011, Osec business review.

Pfeffer, J., 2009. Building sustainable organizations: The human factor. Research Paper series, Standford Graduate school of business.

Pfeffer. J., 2006. Kent Thiry \& DaVita: Leadership Challenges in Building and Growing a Great Company. Standford, CA: Standford University, Graduate School of Business, case \# OB-54.

Pischke, J. S., 2000. Continuous Training in Germany. Discussion Paper No. 137

Poulet, R. 1997. Designing effective development programmes. Journalof Management Development. 16.5-6, p428.

Quraishi, M. 1997. Training programme for junior trainees. Economic Review (05318955), 28(4), 23.

Raza, Ali., Frahan, M., Usman, M. \& Akram, M. 2011. Analysis of Financial Sector Reforms and Impacts: Reflections from Pakistan. Information Management and Business Review Vol. 3, No. 2, pp. 91-102.

Rowden, R. W.2007. Moving From Training to Workplace Learning, Western Region Research Conference on the Education of Adults (WRRCEA).

Rahim, S. H. 2010. Emotional Intelligence and Stress: An Analytical Study of Pakistan Banks. International Journal of Trade, Economics and Finance, Vol. 1, No. 2.

Ramlall, S. 2004. A review of employee motivation theories and their implications for employee retention within organizations. Journal of American Academy of Business, 5(1/2), 52-63.

Saks, A.M. \& Belcourt, M. 2006. An investigation of training activities and transfer of training in organizations. Human Resource Management, 45, 4, 629-48.

Sathar, Z. A. 2001. Fertility in Pakistan: Past, Present \& Future. Workshop on prospects for fertility decline in high fertility countries, Population Division, Department of Economic \& Social affair, United Nations Secretariat, New York.

Schmidt, S. W., 2007. The Relationship Between Satisfaction with Workplace Training and Overall Job Satisfaction. Human Resource Development Quarterly, vol. 18, no. 4.

Sharif, M. Y., Ahmad, A., Kausar, A. R., \& Town, C. I. J. 2011. A Comparative Study on the Effectiveness of Human Resource Professionals in Pakistan and Malaysia. Inventi Impact: Human Resource.

Smits, H. 2006. 5 Levels of Agile Planning: From Enterprise Product Vision to Team Stand-up. Rally Software Development Corp.

Swanson, R.A., 1995. Human Resource Development: Performance is the key. Human Resource Development, Quarterly, 6 (2), 207-213.

Tessema, M. T. \& Soeters, J. L. 2006. Challenges and prospects of HRM in developing countries: testing the HRM-performance link in the Eritrean civil service. Int. Journal of Human Resource Management 17:1, 86-105

Thomas, J. A. \& Hairston, R. V. 2000. Continuous Training and Firm Productivity in Germany. ftp:// ftp.zew.de/pub/zew-docs/dp/dp0250.pdf

Tziner, A., Fisher, M., Senior, T. \& Weisberg, J., 2007. Effects of Trainee Characteristics on Training Effectiveness. International Journal of Selection 
and Assessment Volume 15 Number 2.

Velada, R., Caetano, A., Michel, J. W., Lyons, B. D. \& Kavanagh, M. J., 2007. The effects of training design, individual characteristics, and work environment on transfer of training, International Journal of Training and Development, 11, 282-94.

Vosniadou, S., \& Kollias, V. 2001. Information and Communication Technology and the problem of teacher training: myths, dreams, and the harsh reality. Themes in Education, 2(4), 341-365.

Williamson, J. M., Pemberton, A. E. \& Lounsbury, J. W. 2005. An Investigation of Career and Job
Satisfaction in Relation to Personality Traits of Information Professionals. The Library Quarterly, Vol. 75, No. 2, pp. 122-141.

Williams, M. L., McDaniel, M. A. \& Nguyen, N. T. 2006. A Meta-Analysis of the Antecedents and Consequences of Pay Level Satisfaction. Journal of Applied Psychology 2006, Vol. 91, No. 2, 392-413.

Zhang, Y. C \& Li, S. L, 2009. High performance work practices and firm performance: evidence from the pharmaceutical industry in China. The International Journal of Human Resource Management, Vol. 20, No. 11, 2331-2348. 


\title{
CONTRIBUTOR'S GUIDELINES
}

\begin{abstract}
The management of Jinnah Business Review (JBR) encourages researchers to prepare their articles in accordance with the following guidelines and submit their manuscripts online, preferably. Before submitting your articles online, you will have to transform your article in to our Journal's template; and for this purpose, you can use a specimen provided for the article on our research center's website (www.jbrc.pk) as a base.
\end{abstract}

\section{AIMS AND SCOPE}

Jinnah Business Review (JBR) is the academic research journal of the "Jinnah Business Research Center" of Mohammad Ali Jinnah University, Islamabad (Pakistan). The Journal publishes theoretical and empirical research papers in management, finance, human resource management, marketing and economics, and all other related disciplines of management and social sciences. Its primary focus is on empirical studies with an emphasis on the policy relevance of the findings.

JBR's goals are to inform the academic, business, and public policy communities of the results of relevant current research; to provide expert analysis of current events and reviews of literature in the field; and to add to the business literature material suitable for academics, executives, and professionals.

New innovative concepts, ideas and practices about businesses, industry, and management related disciplines are therefore welcomed. The submitted articles are undergone through a two-tiered review; the first evaluation is carried out by the JBR Editorial Advisory/Working Committee consisting of members from each relevant discipline, and the second review by peer referees and experts working in the related fields in Pakistan and abroad.

\section{INSTRUCTIONS FOR AUTHORS}

The Editors welcome preliminary inquiries about manuscripts for possible publication. There is no standard fixed length for articles, but a $15-20 \mathrm{~A} 4$ pages, with 12 -fonts and 1/1/2-line space article would suffice.

Manuscripts should be prepared according to the following style rules (deviations from these rules can cause publication delays).

\section{Content, Length, and Formatting}

It is the author's responsibility to make the submitted paper readable, relevant, and interesting, before submission and consideration by referees. This require:

\section{Length}

All submitted papers must be formatted according to the instructions below, and must be no more than 15 - 20 US letter pages, as defined earlier. This page limit includes all parts of the paper: title, abstract, body, bibliography, appendices and tables.

\section{Abstract}

An abstract not exceeding 250 words comprising the following is required in the following format:

Author's name (s) and affiliation
a) Email address
b) Title and abstract content

The abstract content should clearly state:

a) Research questions and/or objectives

b) Methodology

c) Scope of investigation/findings

\section{Full paper}

a) A4 size paper

b) Margins must be 1 inch on all sides

c) Font size 12 Times New Roman (body text)

d) Title, subtitles, abstract and references single spaced; body text $1 \frac{1 / 2}{2}$ line spaced

e) Referencing, graphics \& tables will be considered in the total page count.

f) Do not include page numbers, header \& footer.

g) Maximum $15-20$ pages

h) Other formatting details see next section

\section{Tables and Figures}

a) All unessential tables and figures should be eliminated. 
b) Tables must be submitted in Microsoft Word table format, and should be created using Times New Roman text, 10 point size. APA-style provided elsewhere must be preferred.

c) Figures must be clearly produced in black and white. All text included in figures should be Times New Roman (10 point minimum).

d) Each table and figure should fit on a single page. Tables and figures may be oriented horizontally (landscape) or vertically (portrait) within the allotted space.

e) Each table and figure should be submitted on a separate sheet and identified with a table or figure number and a descriptive title.

f) Legends and titles on tables and figures must be sufficiently descriptive such that they are understandable without reference to the text.

g) For data not generated by the author(s), the source of the data should be given (in short form) below the table or figure and listed in full in the references.

h) Every table and figure must be referred to in the text. Each table and figure will appear in the journal after its first mention in the text.

\section{File type}

All papers are to be submitted as a single MS WORD file, formatted for $8.5^{\prime \prime} \times 11^{\prime \prime}$ paper. It is essential that submitted papers print without difficulty on a variety of printers.

\section{Anonymity Requirements for Double-Blind Reviewing}

All research papers submitted to JBR will undergo a "double-blind" reviewing process: the program committee members and referees who review the paper will not know the identity of the authors. To ensure anonymity of authorship, authors must prepare their manuscript as follows:

a) Authors' names and affiliations must not appear on the title page or elsewhere in the paper.

b) You must also use care in referring to related past work, particularly your own, in the paper. The following types of statements must be avoided:

'In our previous work [1,2], we presented two algorithms for that work by In this paper, we build on

\section{Footnotes and References}

a) Footnote material should be incorporated into the text whenever possible. If footnotes are necessary, the note number should be typed in the text and superscripted. The notes should be collected at the end of the text as endnotes.

b) References should be (a) integrated into the text in short form and (b) collected together at the end of the article. APA format needs to be followed.

\section{i) In-text, citations should be placed in} parentheses and noted as follows:

For book or academic journal - (last name of author[s], date); such as: (Hill, 1988); (Beatty, 1989; Feltham, et al. 1991; Leland \& Pyle, 1977).

If no author, cite journal, institution, or publisher. For works with three or more authors, list the first author followed by "et al." as shown above. For multiple citations, alphabetize citations by first author's last name.

ii) The full bibliographic information in the references should be composed as follows:

For book - author[s]. year. book title. edition number [if applicable]. location: publisher.

Such as: Yin, R.K. (2003). Case Study Research:

Design and Methods. 3rd Edition. Thousand Oaks, California: Sage Publications, Inc.

For edited volume-editor[s] (ed[s].). year. book title. edition number [if applicable]. location: publisher.

Such as: Nelson, R.R.(ed.).(1993). National Systems of Innovations: A Comparative Analysis. Oxford: Oxford University Press.

For chapter in edited volume - author[s]. year. "chapter title." in editor[s] (ed[s].). book title, pp. chapter page numbers. location: publisher.

Such as: Groenewegen, John and Jack Vromen (1997). "Theory of the firm revisited: New and neoinstitutional perspectives." In Lars Magnusson and Jan Ottosson (eds.) Evolutionary Economics and Path Dependence, pp. 33-56. Cheltenham, UK: Edward Elgar.

For article in academic journal - author. year. "article title." journal title. volume number (issue number): page numbers. 
Such as: Black, J.S., Gregersen, H.B. \& Mendenhall, M.E. (1992). "Toward a Theoretical Framework of Repatriation Adjustment." Journal of International Business Studies 23 (4): 737-760.

The author(s) should make sure that there is a strict one-to-one correspondence between the in-text citations (including citations in footnotes, tables, and figures) and the list of references in the References.

\section{Copy Preparation}

JBR accepts manuscripts via internet or post or e-mail. All hard-copy submissions must be accompanied by a disk or $\mathrm{CD}$ containing an electronic version of the manuscript. The manuscript should be prepared using a recent version of Microsoft Word and should utilize standard fonts and symbols. Ideally, such a manuscript should be formatted with regard to the following guidelines:

a) Do not use tabs except in tables.

b) Do not indent block quotations.

c) Do not hyphenate or otherwise break words across lines.

d) Use headings sparingly and logically. Do not use more than three levels of headings. Use consistent formatting for each heading level employed.

\section{Copyright Transfer}

a) Submission of a paper will be held to imply that it contains original unpublished work and is not being submitted for publication elsewhere.

b) Submission of a paper also implies that, upon acceptance of an article by the journal, the author(s) will transfer copyright of the article to the publisher. The transfer will ensure the widest possible dissemination of information.

c) It is understood that submission of the paper for publication has been approved by all of the authors and by the institution where the work was carried out; it is further understood that any person cited as a source of personal communications has approved such citation.

\section{Miscellaneous}

a) Papers must be in English. Use American spelling instead of British (e.g., labor, not labour). Use the American terms such as billion (one billion $=1,000,000,000$; one trillion = $1,000,000,000,000)$, rather than lakhs and crores.

b) Spell out all numbers from one to ninety-nine, unless:

i) the number contains a decimal point, e.g., "6.2" and " 0.12 "

ii) the number precedes a percent sign or a unit of measure, e.g., " $47 \%$ " and " $16 \mu \mathrm{m}$ "

c) Italicize and define non-English words at their first occurrence; at subsequent occurrences, format the word in roman (no italicized) type.

d) A short abstract of the paper should always be included with the submission.

e) Please keep a copy of everything sent to JBR, both hard copy and electronic copy, and bear in mind that the electronic version received at JBR will be considered the master copy. The Editors do not accept responsibility for damage to or loss of submitted papers or electronic media.

f) A short note listing each author's institutional affiliation, current address, telephone numbers, e-mail address, and other relevant biographical information, including publications and a photograph should be provided.

g) Any manuscript that does not conform to the above instructions may be returned for the necessary revision before publication.

h) Each author is entitled to one copy of the issue in which his or her article appears.

Note:

Editor reserves the right to amend, abridge or otherwise alter the contents of the paper to make it suitable for publication. However every endeavor will be made not to affect the spirit or effectiveness of the paper. 




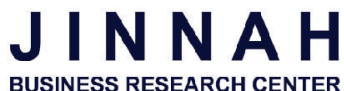

Mohammad Ali Jinnah University

Islamabad Expressway, Kahuta Road, Zone-V, Islamabad, Pakistan
ISSN 2070-0296

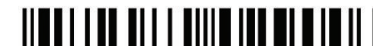

$9\left\|_{772070}\right\|_{029007}$ 